\title{
AN ECONOMIC ANAL YSIS OF THE FACTORS AFFECTING THE POSITION (SITE) OF SMALL INDUSTRIAL INSTALLATIONS IN EGYPT (WITH SPECIAL REFERENCE TO THE UPPER EGYPTIAN REGIONS)
}

(Received: 25-3-2015)

\author{
By \\ M. N. A. Ahmed and Y.H.A.Ali* \\ Faculty of Commerce, Sohag University, Egypt. \\ *The high Institute for Administrative Sciences, Sohag, Egypt.
}

\begin{abstract}
The current research aimed at identifying the factors affecting the choice of small industrial installation sites, and to determine the relative importance of each of them in the different site categories (Cities), and the relationship between the site and officials' backgrounds of all small industrial installations, and their most important structural features. Results of the present research have shown statistically significant correletion between the size of the site (cities categories) and small industrial installations officials' backgrounds (educational, artisitc, family, and vocational) in upper Egyptian regions. There was also a statistically significant correlation relationship between the size of the site (cities categories) and some of the structural features of small industrial installations (property format, the volume of employment, investment in machinery and equipment, sources of machinery used, market size, sources of raw materials, manufactured products, the use of the facilities available in Upper Egyptian regions.

In the light of the reached results, through the field study,the current research recommended immediately drawing an industrial map of Upper Egyptian regions, and distribute the industrial installations that will be established accomplishing policy manufacturing, geographic distribution accomplishing policy on the scientific foundations for industrial housing construction planning and regional development, and to strengthen and consolidate distribution channels currently available in upper egyptian regions, through the creation of new and large collective and retail markets, in all categories of the site (especially small ones).
\end{abstract}

Key words : small industrial installations, upper Egyptian regions.

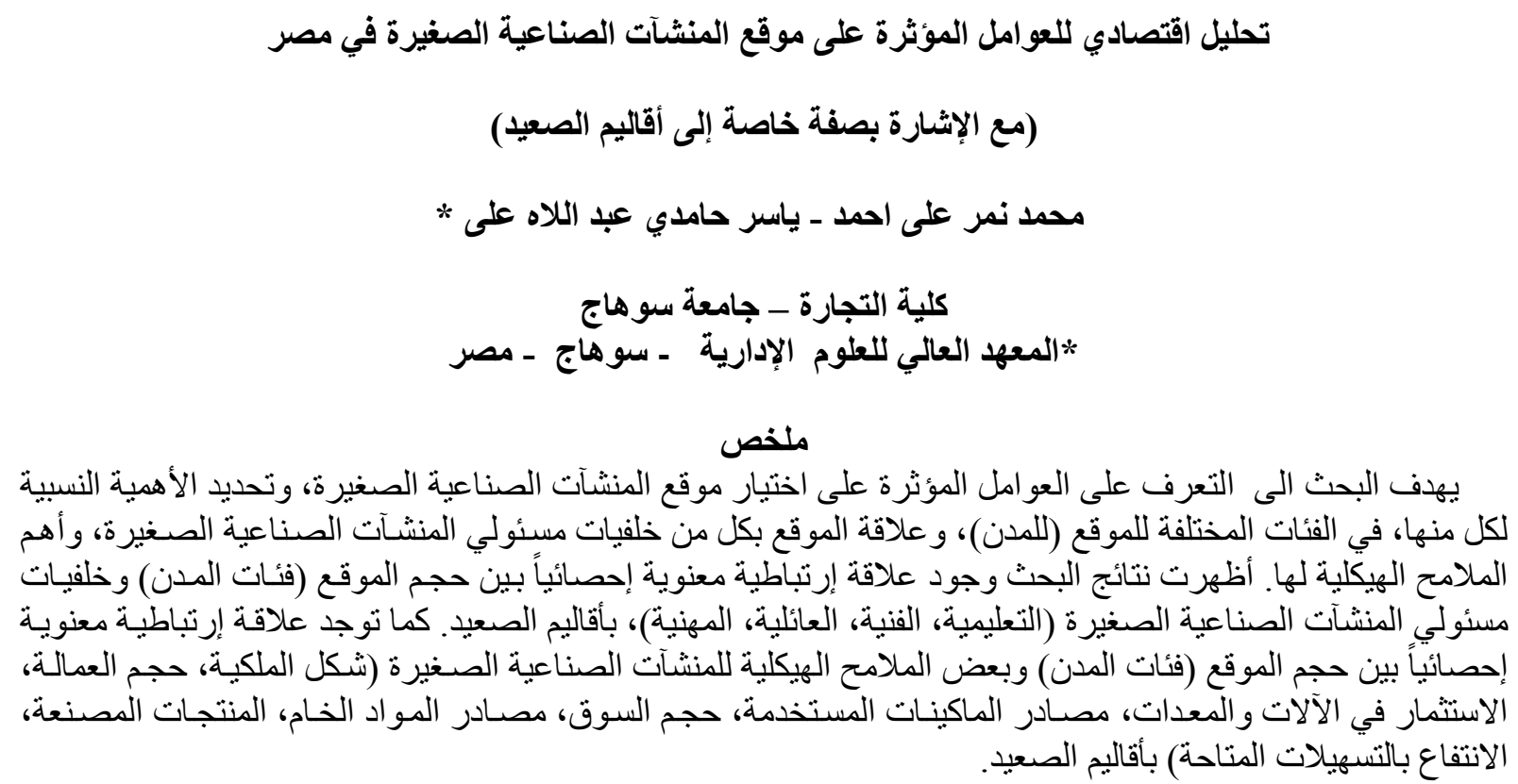




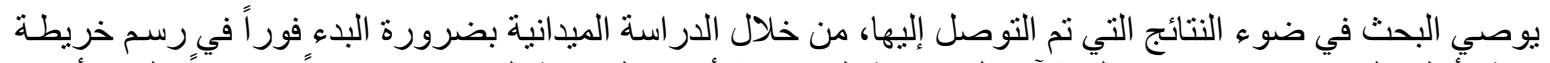

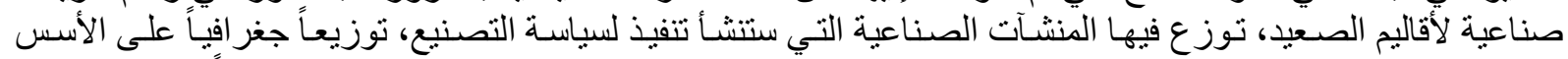

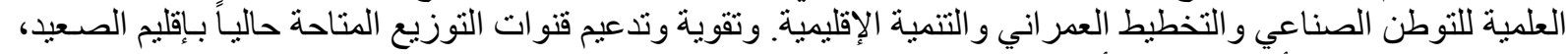
وذلك من خلال إنشاء أسو اق جملة وأسو اق تجزئة جديدة وو اسعة، في جميع فئات الموقع (وخاصة الصغئة الصغيرة منها).

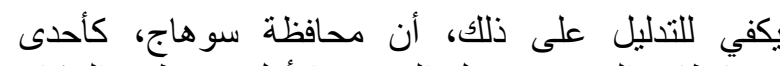

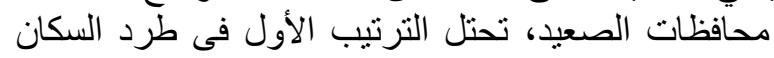

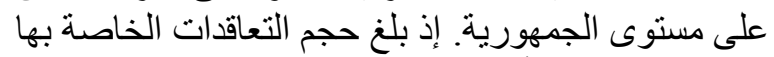

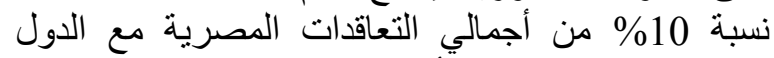

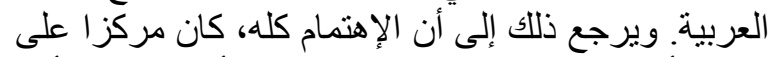

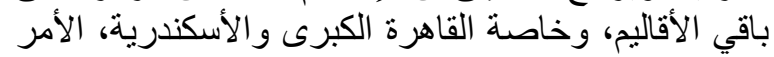

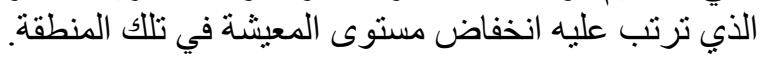

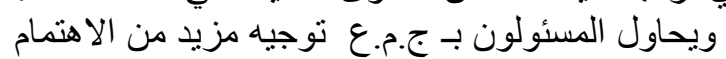

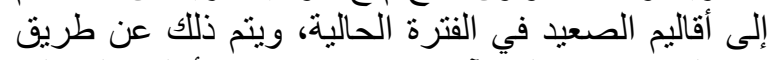
محاولة توطين المنشآت الإنتاجية في الأقاليم المختلفي طنة

للصعيد. محون

وتعتبر المنشآت الصناعية الصغيرة أهم البدائل

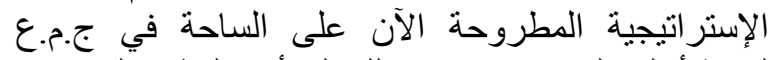

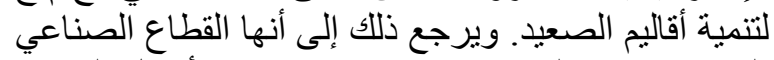

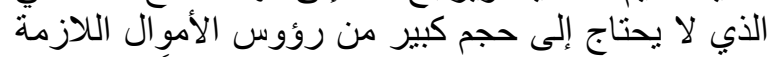

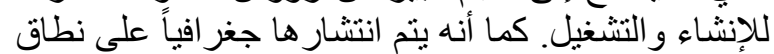

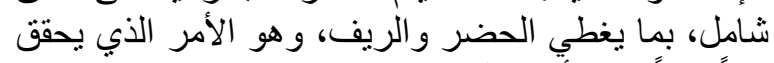

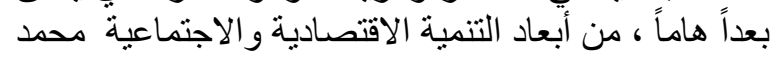

وحتى ينت القيام بعملية توطين المنشآت الصناعية

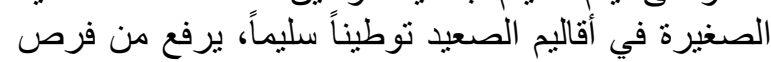

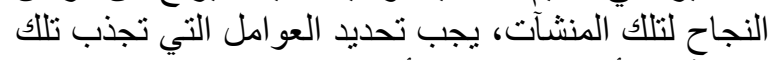

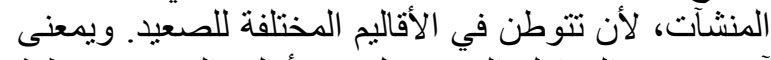

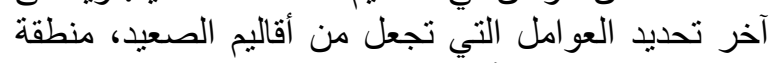

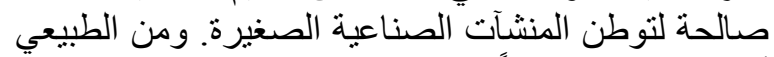

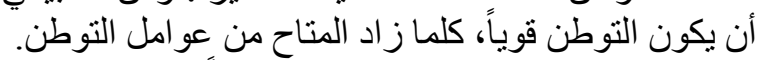

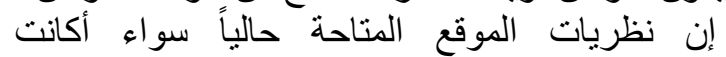

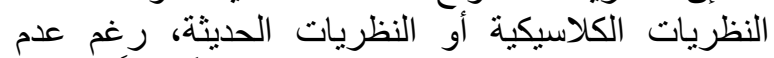

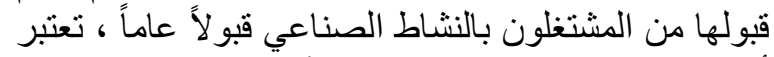

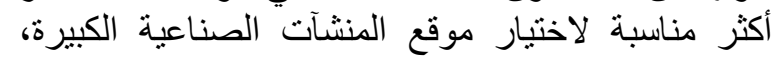

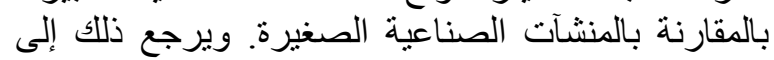

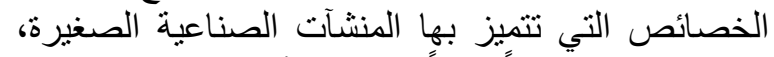

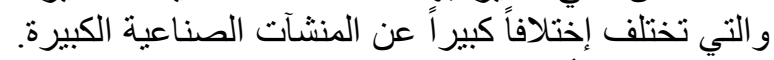

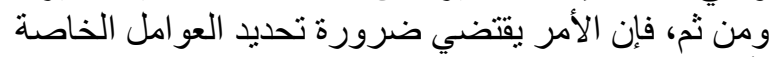
بأختبار موقع المنشآت الصناعية الصغيرة الصنيرة

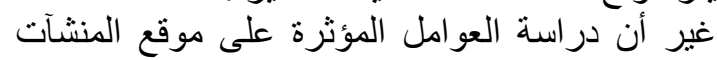

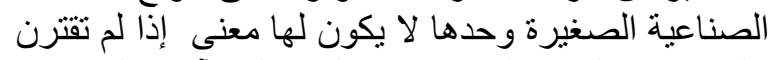

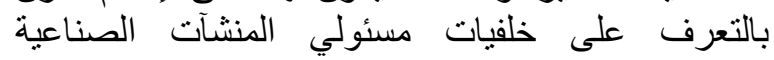
الصغيرة (التعليمية، الفنية، العائلية، المهنية) والمئية الملاثح

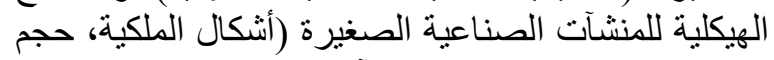

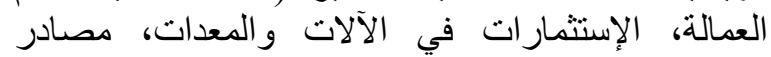

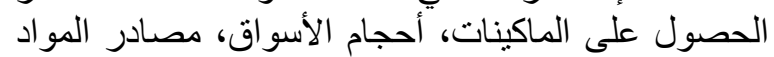

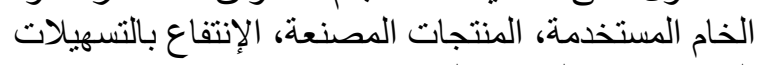
المتاحة) ذات العلاقة بالموقع. وفي محاولة للتعرف بلى المّلى العو امل المؤثرة على أختيار

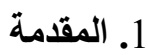

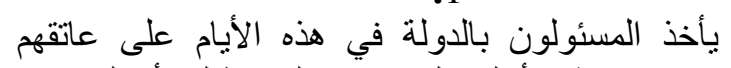

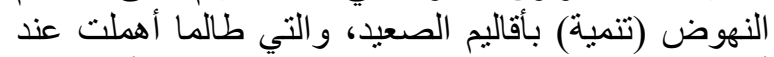

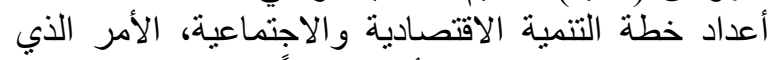

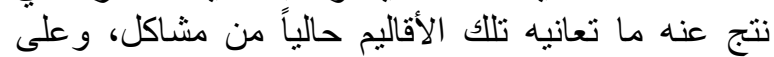

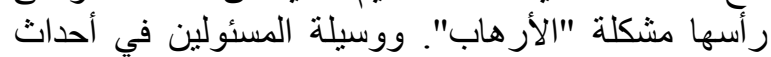

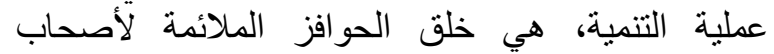

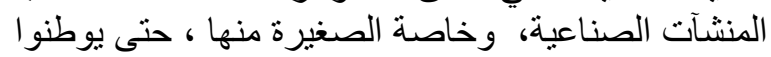

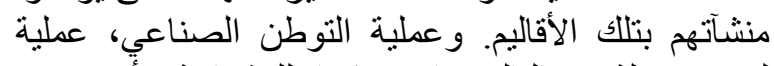

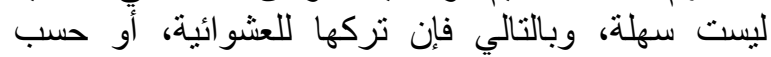

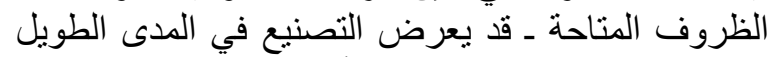

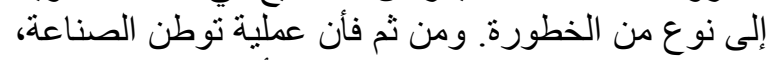

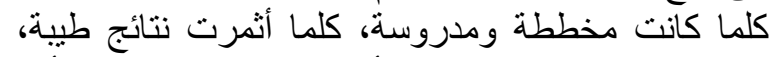

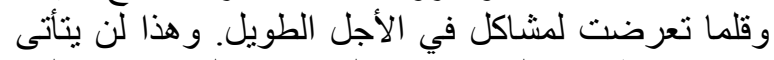

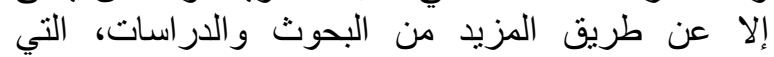

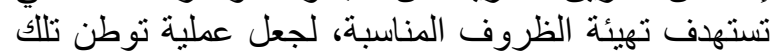

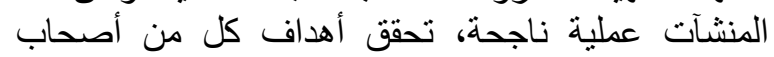

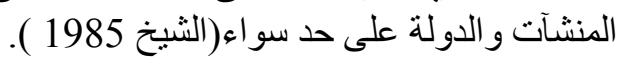

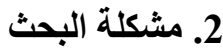

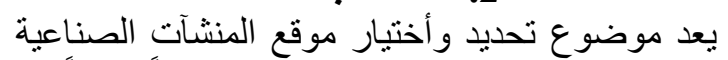

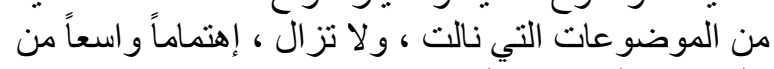

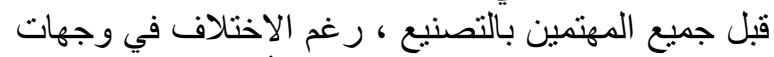

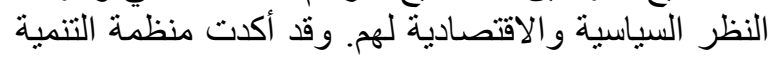

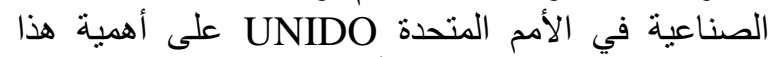
الموضوع، بغية تحقيق مبدأ النمو الإقليمي المتوازن الهئ. .Regional Equilibrium Growth

وتشير خريطة الصناعة في ج.م.اع.ع وتوزيعها

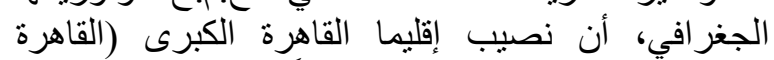

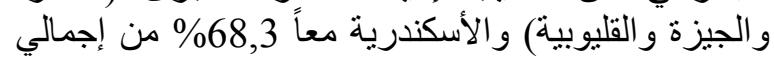

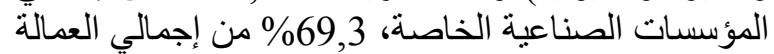

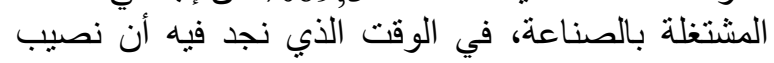

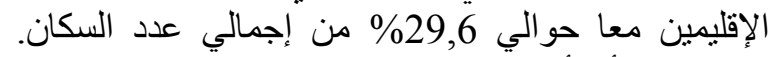
و هذا يعني أن أكثر من ثلث الثر الصناعة، تتركز في في القاهرة

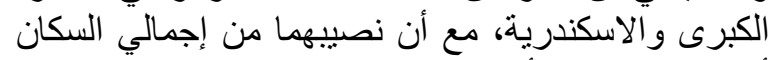
أقل من 30\%. الأمر الذي يعكس الاعس عدم التوازن آلجغر افي التي

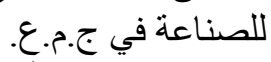

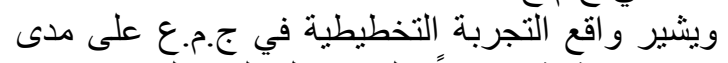

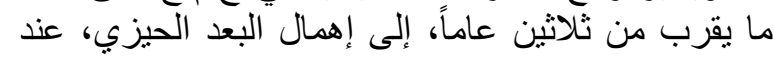

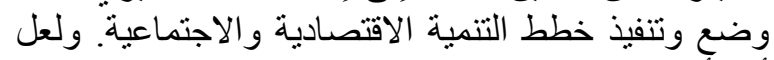

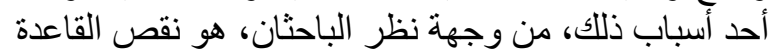

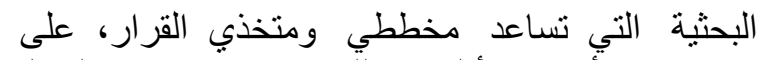
الاهتمام بالأبعاد الأقليمية للتنمية (درويش والزية الزقالى

وتعتبر منطقة الصعيد من المناطق الطاردة للسكان. 
يتسنى للباحث تقديم الاقتر احات التي يرونها مناسبة لدعم توطن المنشآت الصناعية الصغيرة بأقاليم الصعيد.

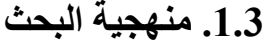

أنتهج لإجر اء هذا البحث، الأسلوبين التهاء التاليين:

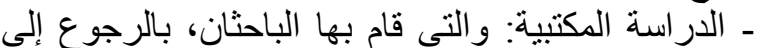

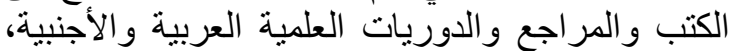

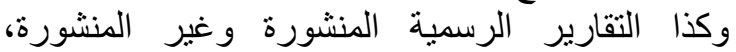

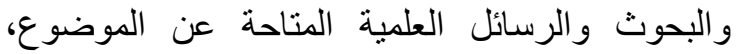

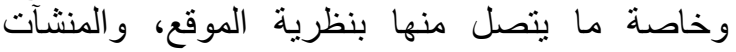
الصناعية الصغيرة.

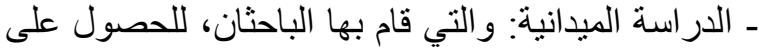

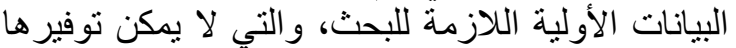

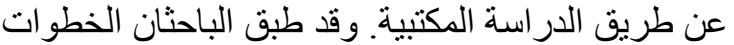

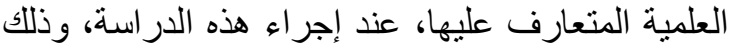
على النحو التالي: النعارف

يتكون مجتمع البحث من جميع المنشتآت الصناعية الصغيرة، طبقاً لمفهو مها المستخدم في هذا البحث، و والبالغ عددها 762 منشأة موزعة على 43 مدينة مدينة من مدن أقاليم

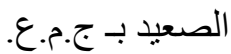
وقد شمل البحث عينة من المنشآت الصناعية الصغيرة

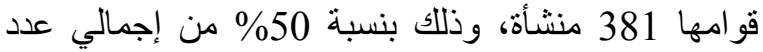

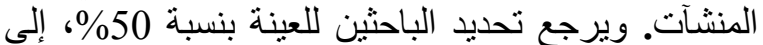

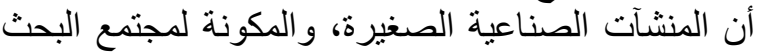

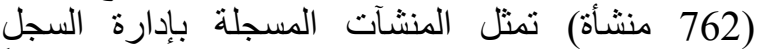

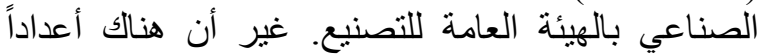

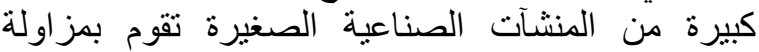
نشاطها، ولكنها غير مسجلة و عددها (34) منشآة الأمر

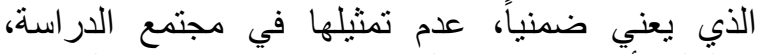

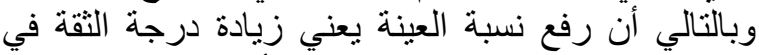
النتائج، ومن ثم إمكانية تعميمها. وقد أختار الباحثنان العينة

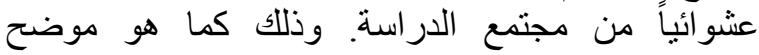

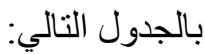

وقد تم جمع البيانات من مفردات العينة، عن طريث البيق

المقابلات الشخصية بواسطة الباحثان ومجمو عة مساعدة

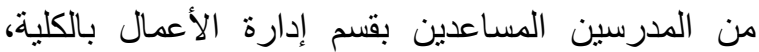
و الباحثين الاقتصاديين بفرع الهيئة العامة للتصنيع بمدينة

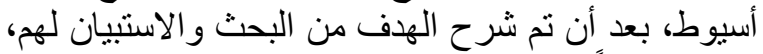

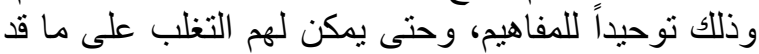

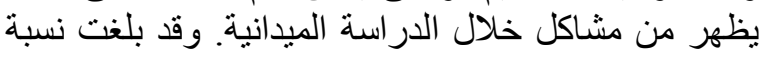
الاستجابة Rate of Response التي تم الحصول عليها \% 100 و أستخدم الباحثنان بعض الأساليب الإحصائية المناسبة
موقع المنتآت الصناعية الصغيرة، وتحديد الأهمية

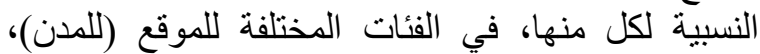
و علاقة الموقع بكل من خلفيات مسئولي المنشآت الصناعية الصغيرة، وأهم الملامح الهيكلية لها، يدور موضون فئوع البحث 122 التساؤلات الآتية

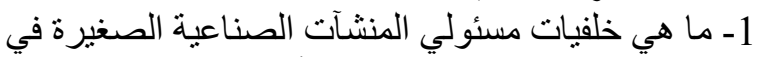

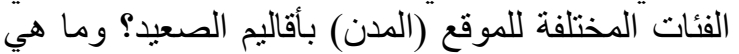

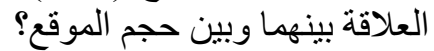

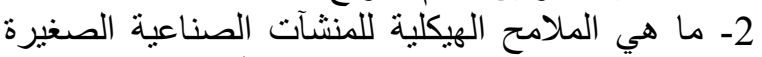

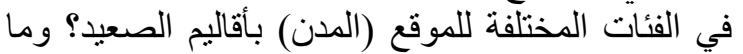

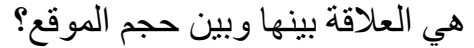

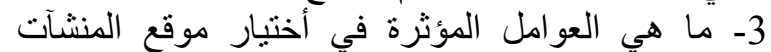
الصناعية الصغيرة، بأقاليم الصوئ فيد؟ وما هي هي الأهمية النسبية لكل منها؟

2.2. فروض البحث

بناء على الدراسة الباستطلاعية التي قام بها الباحثان فأن فروض البحث تتمثل في ثلاثة فروض رائيسية هي: الأنية الفرض الأول: "توجد علاقة إرتباطية دالة إحصائياً بين فين فئين

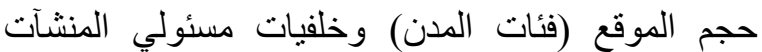

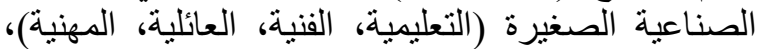
بأقاليم الصعيد". الفرض الثاني: "توجد علاقة إرتباطية دالة إحصائياً بين

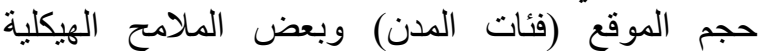
للمنشآت الصناعية الصغيرة (شكل الملكية، حجم العمالة،

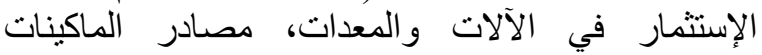

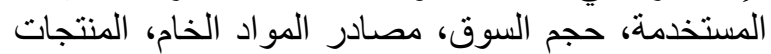

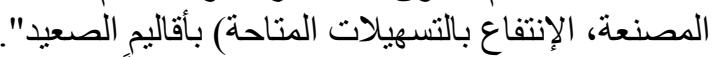

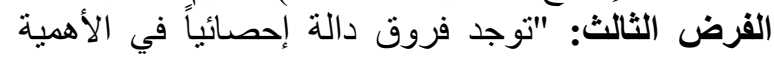

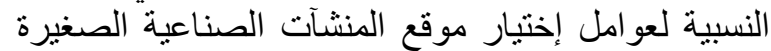
في الفئات المختلفة للموقع (للمدن)، حيث يتوقع الباحثنان،

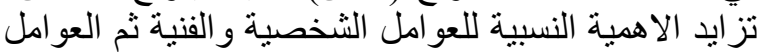
الإقتصادية، وتقل الأهمية النسبية للعو امل الأجتماعية".

\section{3. أهداف البحث}

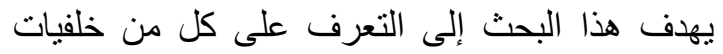
مسئولي المنشآت الصناعية الصغيرة، والمالامح الهيك الهيكلية

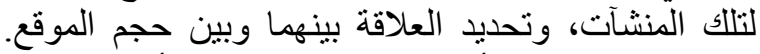

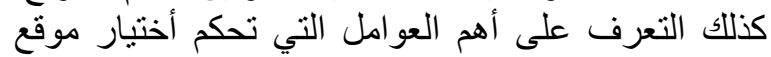

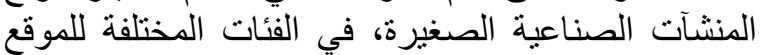

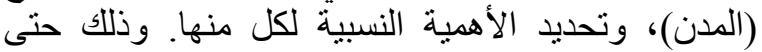

جدول (1) : موقع المشروعات الصناعية الصغيرة في اقاليم الصعيد و عدد المدن والمنشات بها .

\begin{tabular}{|c|c|c|c|c|c|c|c|c|}
\hline \multicolumn{2}{|c|}{ الإجمالي } & \multicolumn{2}{|c|}{ أقليم جنوب الصعيد } & \multicolumn{2}{|c|}{ أقليم أسيوط } & \multicolumn{2}{|c|}{ إقليم شمال الصعيد } & \multirow{2}{*}{ (فئات المدن) } \\
\hline عدد المنشآت & عدد المدن & عدد المنشآت & عدد المدن & عدد المنشآت & عدد المدن & عدد المنشآت & عدد المدن & \\
\hline 138 & 8 & 49 & 4 & 37 & 1 & 52 & 3 & فئة - 1 \\
\hline 79 & 11 & 28 & 4 & 6 & 1 & 45 & 6 & فئة ـ - 2 \\
\hline 70 & 13 & 30 & 7 & 14 & 4 & 26 & 2 & فئة - 3 \\
\hline 43 & 5 & - & - & - & - & 43 & 5 & فئة - 4 \\
\hline 51 & 6 & 26 & 3 & 3 & 1 & 22 & 2 & فئة - 5 \\
\hline 381 & 43 & 133 & 18 & 60 & 7 & 188 & 18 & الإجمالي \\
\hline
\end{tabular}


العليا، وحجم الموقع (المدن)، إذ يلاحظ أن أعدادهم تنز ايد

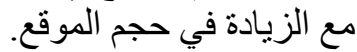

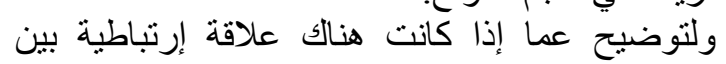
المستويات التعليمية المختلفة لمسئولي المنشآت الصنات المناعية

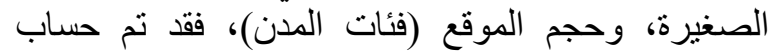
معامل الإرنباط المتعدد، كما نم إستخدام تحليل التباين التهاب

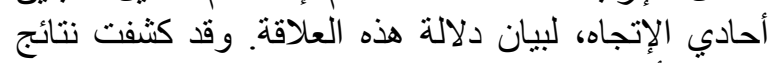

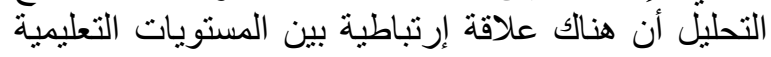

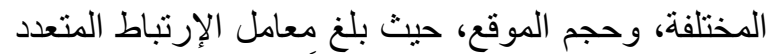

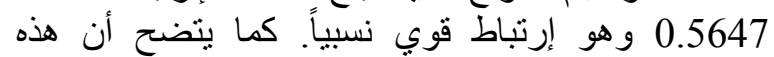

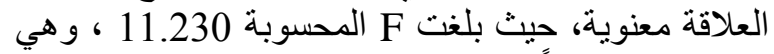

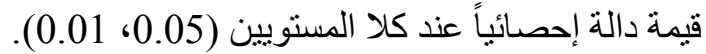

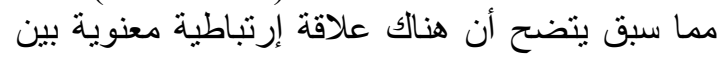
كل من حجم الموقع والخلفية التعليمية لمسئولي المنشآت المنات

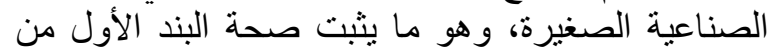
الفرض الأول للبحث.

الموقع والخلفية الفنية لمسئولي المنشآت الصناعية

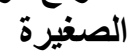

أن نوزيع مسئولي المنشآت الصناعية الصغيرة ، طبقاً

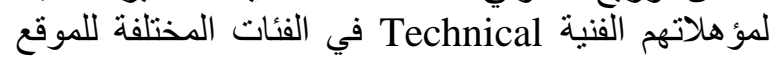

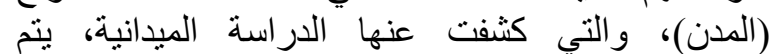

توضيحها من خلال الجدول رقم (4) النّات

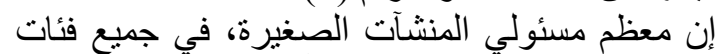

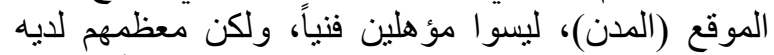

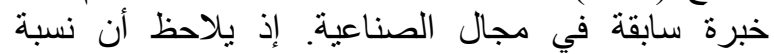

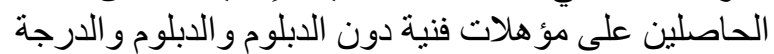

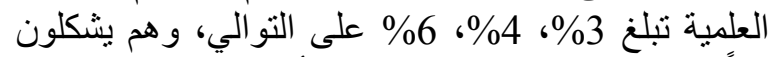

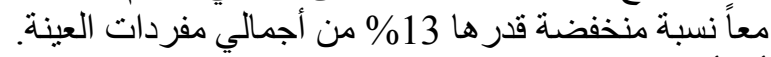

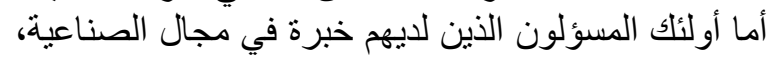

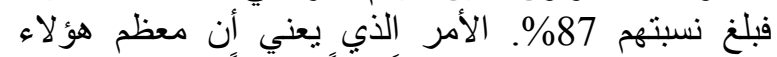

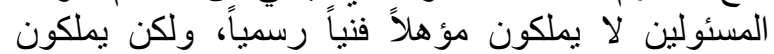

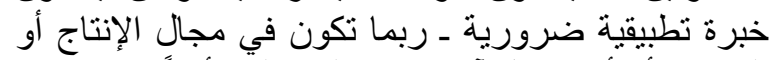

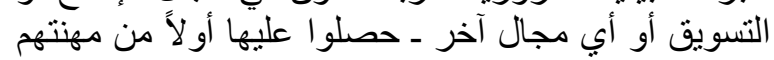

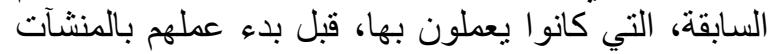

$$
\text { الصناعية الصغيرة. }
$$

وقد أفاد التحليل الاحصائي ، بأن هذه النتائج معنوية ، ولائل

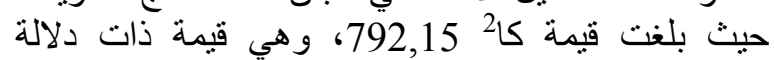

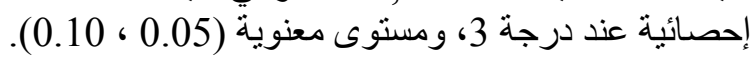

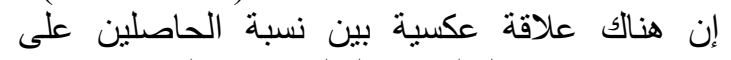

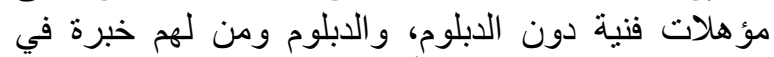

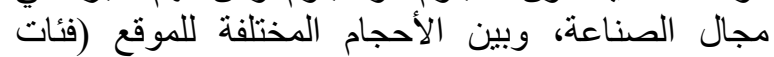

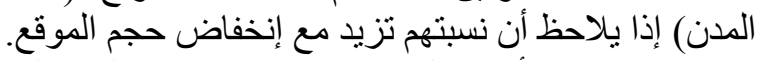

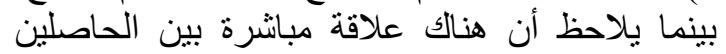

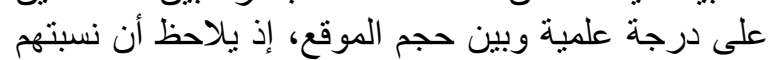

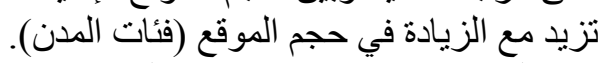

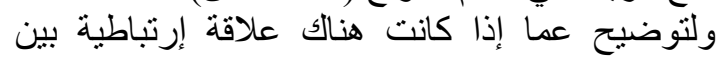
المؤهلات الفنبة المختلفة لمسئولي المنتآت المنات الصناعية

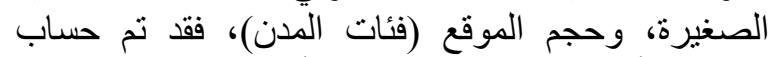

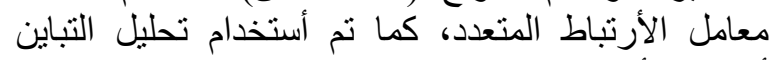
أحادي الأتجاه، لبيان دلالة هذه العلاقة. وقد كثفت نتائج
لتحليل البيانات وأختبار مدى صحة فروض البحث مثل

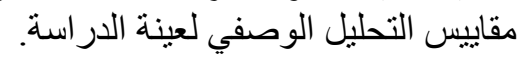

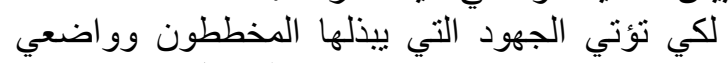

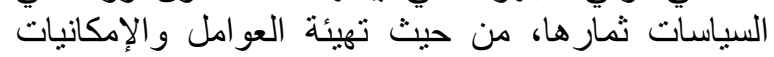

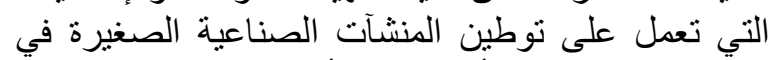

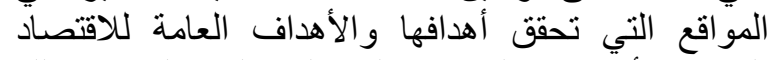

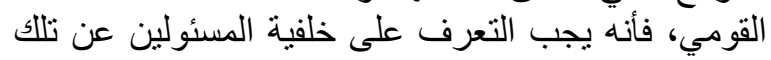

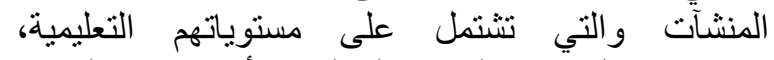

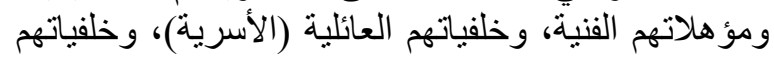
المهنية في المو اقع المختلفة. إن التعرف فئلى التع خلفية مسئولي المنشآت الصناعية

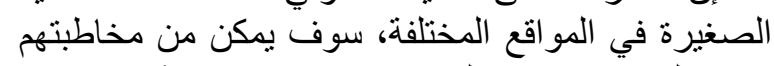

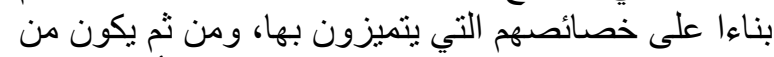

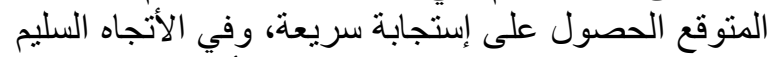

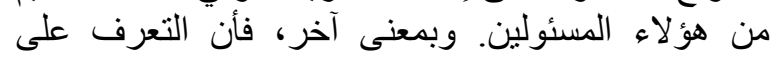

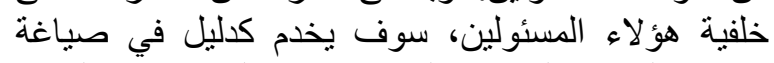

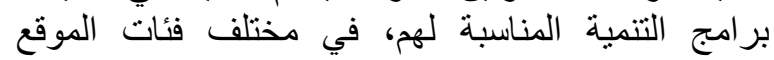

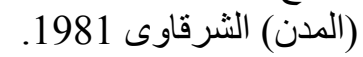

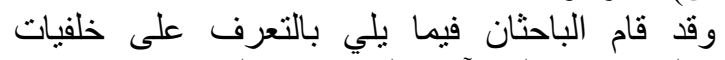

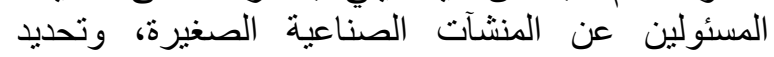

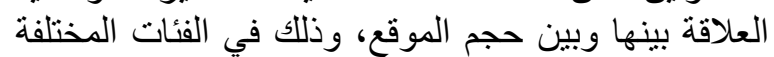

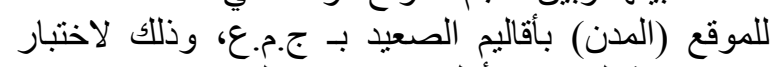
مدى صحة الفرض الأول من فروض البح البحث:

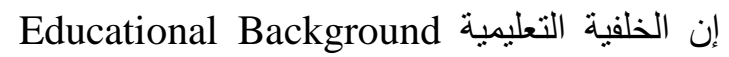
لمسئولي المنشآت الصناعية الصغيرة، في الفئات الصنية المختلفة

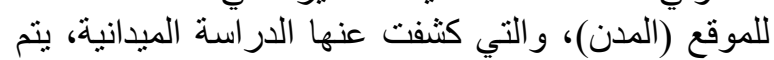

توضيحها من خلال الجدول (1) التي كند (1).

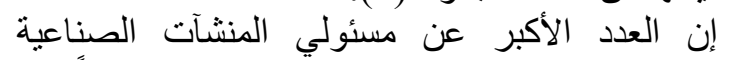

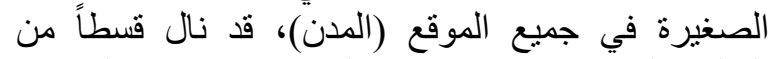

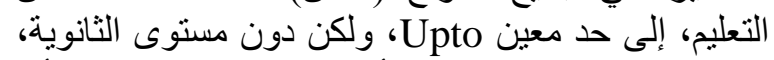

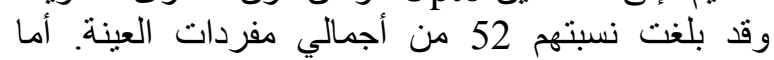

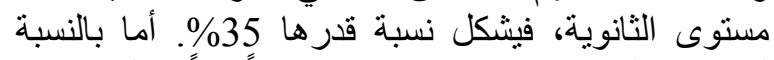

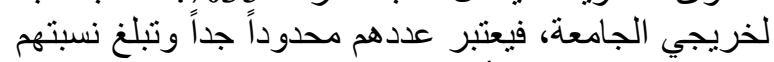

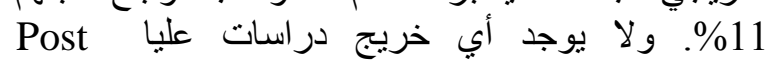

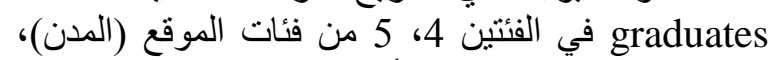
وتبلغ نسبتهم في الفئات الأخرى 2.

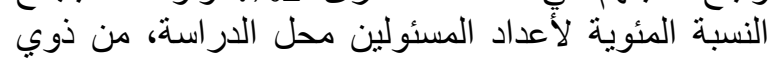

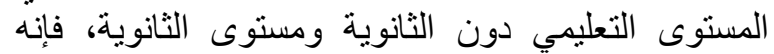

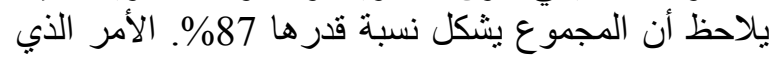

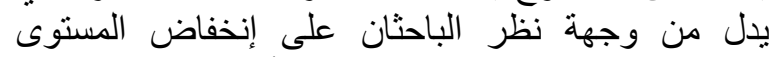
التعليمي لمسئولي المنشآت الصناعية بأقأليم الصعيد. وقد أفاد التحليل الإحصائي بأن هذه النتائج النجائن معنوية،

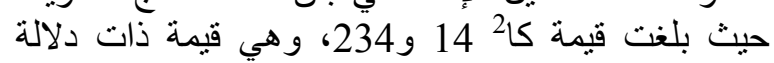

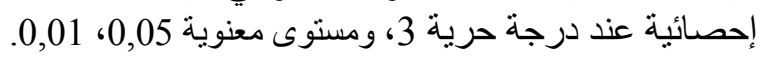

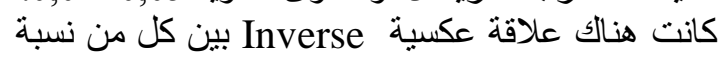

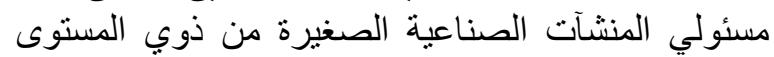

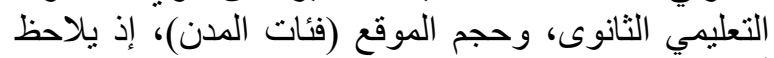

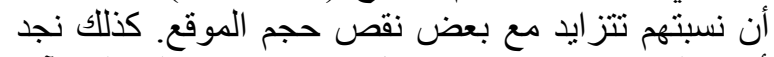

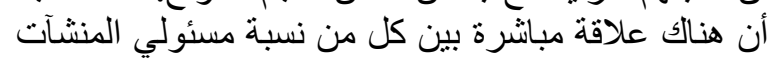

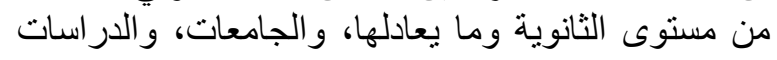


الأتجاه لبيان دلالة هذه العلاقة. وقد كثفت نتائج التحليل أن أن التهات

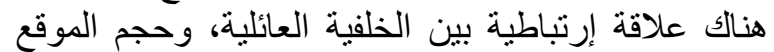
(فئات المدن)، حيث بلغ معامل الأرتباط المتعدد 7.623

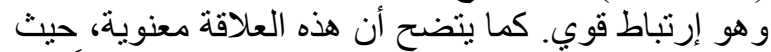

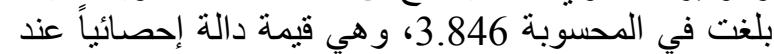
مستوى معنوية 05, مئر مما سبق يتضح أن هناك علاقة إرتباط بين الخلفية

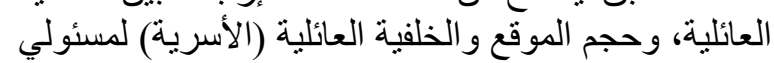

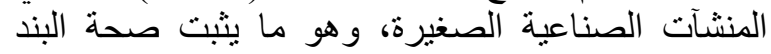
الثالث من الفرض الأول للبحثي

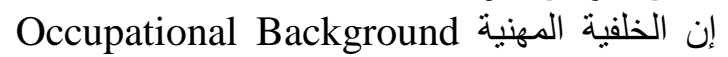

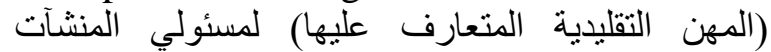
الصناعية الصغيرة، والتي كثفت عنهارفا الدراسة الميدانية،

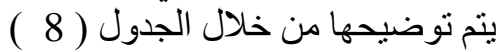
إن النسبة الكبرى من مسئولي المنشآت الصنات الصناعية

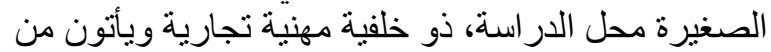

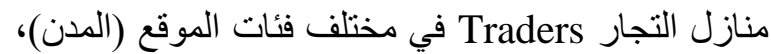

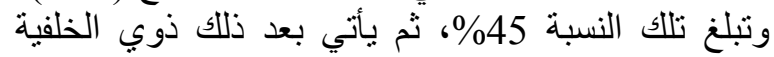

المهنية الصناعية بنسبة قدر ها 27\%

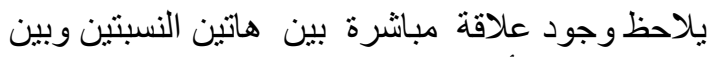

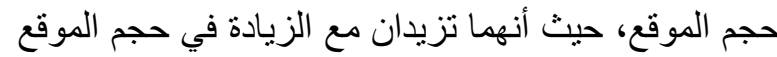

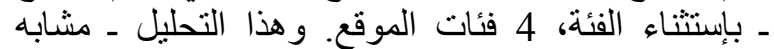
للتحليل السابق مباشرة، بالخلفية العائلية (الأسرية) يشير إلى أن هنالك نسبة كبيرة من مسؤلي المنشآت الصناعة فئنة

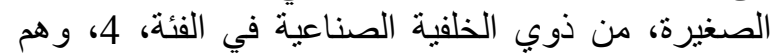

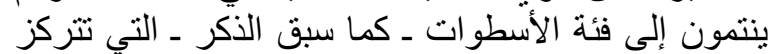

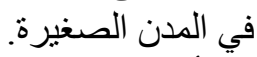

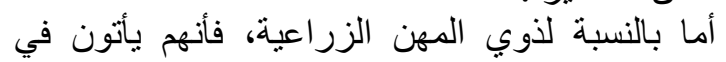

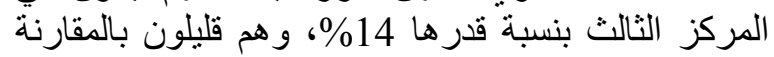

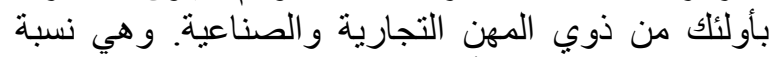

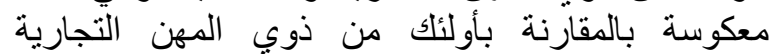

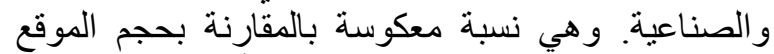
(المدن)، مع تركيز النسبة بصورة أكبر في المواقعة بـعة

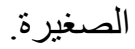
أما بالنسبة لأولئك الذين يأتون في القطاع الخدمي، فهم

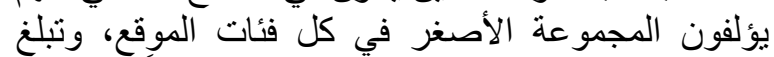
نسبتهم 10\% من أجمالي مفردات العينة. و وأخير أ، فأنه فيما يتعلق بالمهن الأخرى، فيلاحظ أنهم يشكلون نسبة صغية صغيرة

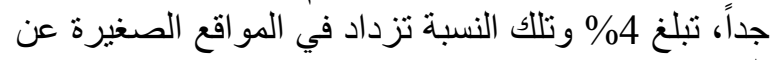

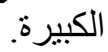
وقد أفاد التحليل الإحصائي بان هذه النتائج معنوية،

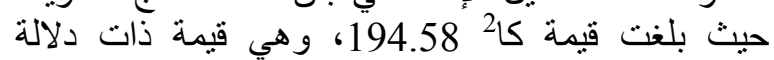
إحصائية عند درجة حرية 4 ومستوى معنوية ,0.05، فئة ذاتل 0.01

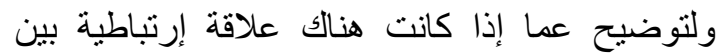

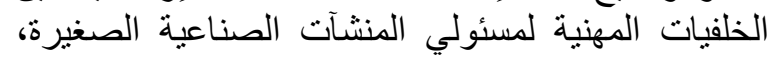

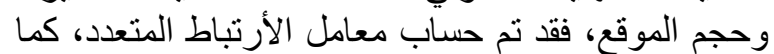

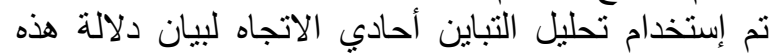

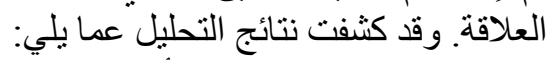
يتضح من الجدول (9) ، أن هنالك علاقة إرتباطية بين
التحليل أن هناك علاقة إرتباطية بين المؤهلات الفنية

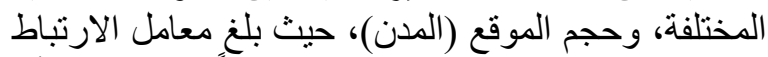

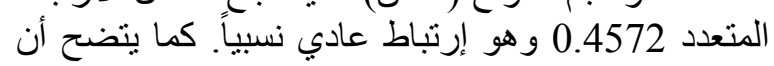

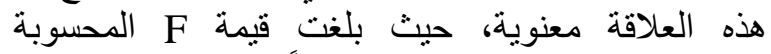
11.230، وهي قيمة دالة إحصائياً عند كلا المسنوينة (0.10 ، 0.05)

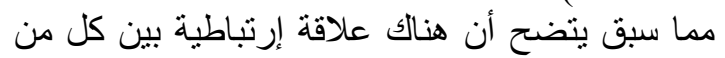

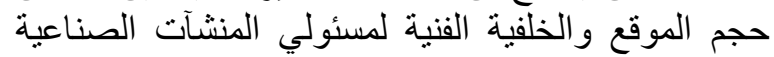

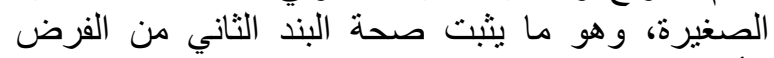

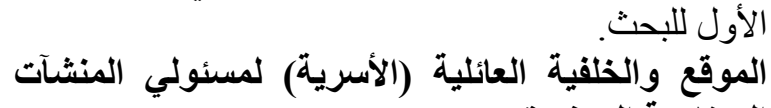
الصناعية الصغيرة إن الخلفية العائلية Family Background لمسئولي المنشآت الصناعبة الصغيرة في الفئات المختلفة للموقع لكئن

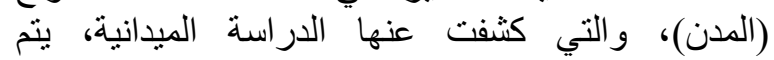

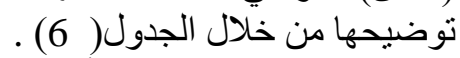

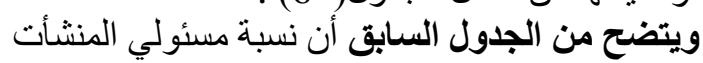

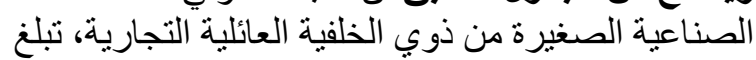

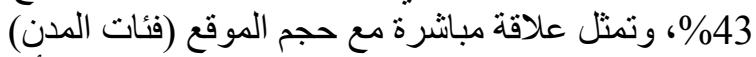

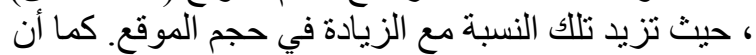

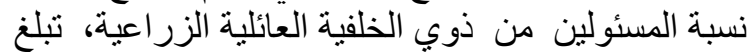

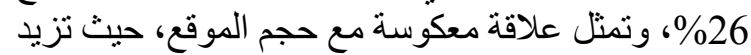

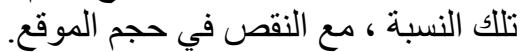

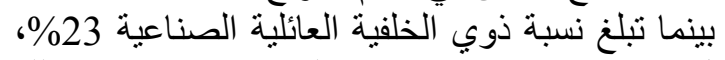

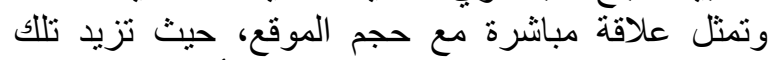

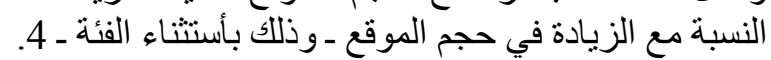

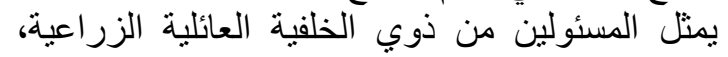

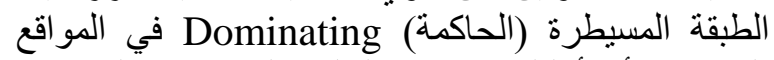

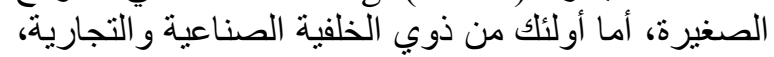

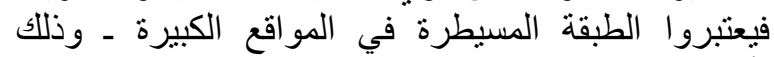
بأستثناء الفئة - 4. كذلك فإن المسئولين من ذوي الخلفية الفئة العائلية التجارية،

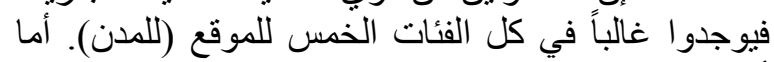

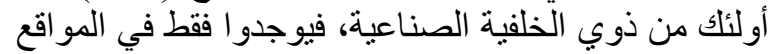

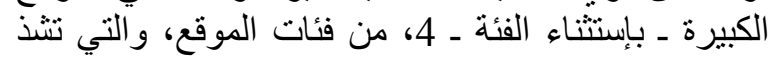

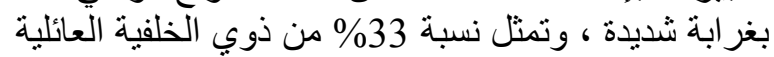

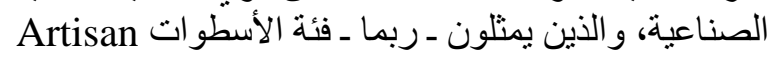

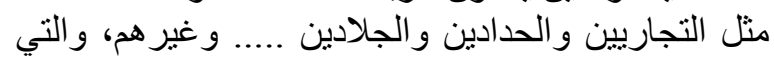
تتركز في المو اقع الصغيرة. 8نبة المسئولين من ذوي الهيرة الخلفية العائلية الخدمية تبلغ

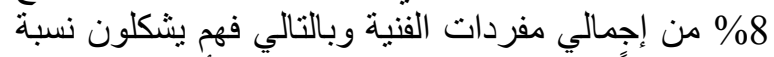

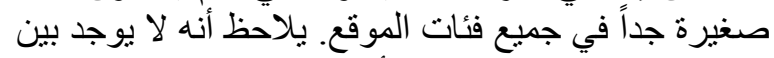

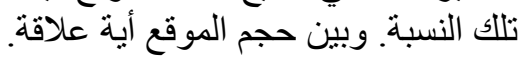
وقد أفاد التحليل الإحصائي بأن هذه المائ النتائج معنوية،

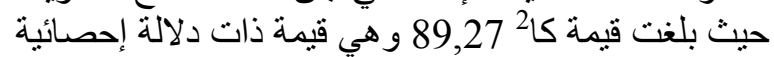

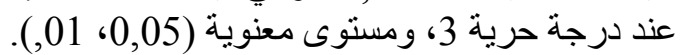

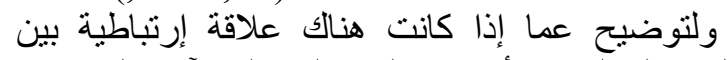

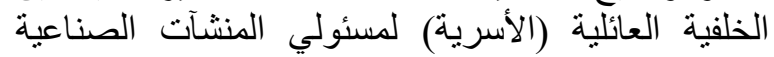

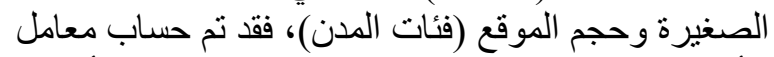
الأرتباط المتعدد، كما تم إستخدام تحليل التباين أحادي 


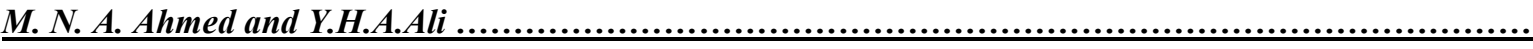

جاول (2): الموقع والخلفية التعليمية لمسئولي المنشآت الصناعية الصغيرة .

\begin{tabular}{|c|c|c|c|c|c|c|c|c|c|c|}
\hline & & & & & & & & \multirow{2}{*}{\multicolumn{2}{|c|}{ إقليم شمال الصعيد }} & \multirow{3}{*}{ (فئات المدون) } \\
\hline \multicolumn{2}{|c|}{ الإجمالي } & \multicolumn{2}{|c|}{ الإجمالي } & \multicolumn{2}{|c|}{ إقليم جنوب الصعيد } & \multicolumn{2}{|c|}{ إقليم أسيوط } & & & \\
\hline$\%$ & عدد & $\%$ & عدد & $\%$ & عدد & $\%$ & عدد & $\%$ & عدد & \\
\hline 100 & 138 & 4 & 5 & 14 & 19 & 41 & 57 & 41 & 57 & فئة - 1 \\
\hline 100 & 79 & 2 & 2 & 13 & 10 & 39 & 31 & 46 & 26 & فئة - 2 2 \\
\hline 100 & 70 & 1 & 1 & 10 & 7 & 36 & 25 & 53 & 37 & فئة - 3 \\
\hline 100 & 43 & - & - & 7 & 3 & 28 & 12 & 65 & 28 & فئة - 4 \\
\hline 100 & 51 & - & - & 6 & 3 & 18 & 9 & 76 & 39 & فئة - 5 \\
\hline 100 & 381 & 2 & 8 & 11 & 42 & 35 & 134 & 52 & 197 & الإجمالي \\
\hline
\end{tabular}

جدول (3) : تحليل التباين أحادي الإتجاه لتحديد معنوية العلاقة بين حجم الموقع والمستويات التعليمية لمسئولي المنشآت الصناعية الصغيرة

\begin{tabular}{|c|c|c|c|c|c|}
\hline آلالدالة الإحصائية & $\mathbf{F}$ & التباين المقدر & درجات الحرية & مجموع المربعات & مصادر التباين \\
\hline مغنوية & 11,230 & 1486,850 & 3 & 4460,550 & بين المجموعات \\
\hline & & 132,400 & 16 & 211,400 & داخل المجموعات \\
\hline & & 6578,950 & 19 & & التباين الكلي \\
\hline
\end{tabular}

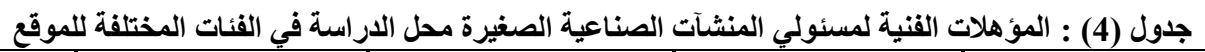

\begin{tabular}{|c|c|c|c|c|c|c|c|c|c|c|}
\hline \multicolumn{2}{|c|}{ الإجمالي } & \multicolumn{2}{|c|}{ خِبرة في الصناعة } & \multicolumn{2}{|c|}{ درجة علمية } & \multicolumn{2}{|c|}{ دبلوم } & \multicolumn{2}{|c|}{ دون الدبلَوم } & \multirow{2}{*}{ (فئات المدنح) } \\
\hline$\%$ & عدد & $\%$ & عدد & $\%$ & عدد & $\%$ & عدد & $\%$ & عدد & \\
\hline 100 & 138 & 86 & 118 & 9 & 13 & 3 & 4 & 2 & 3 & فئة - 1 \\
\hline 100 & 79 & 87 & 69 & 6 & 5 & 4 & 3 & 3 & 2 & فئة - 2 \\
\hline 100 & 70 & 87 & 61 & 4 & 3 & 4 & 3 & 4 & 3 & فئة - 3 \\
\hline 100 & 43 & 88 & 38 & 2 & 1 & 5 & 2 & 5 & 2 & فئة - 4 \\
\hline 100 & 51 & 92 & 47 & 2 & 1 & 6 & 3 & - & - & فَئة - \\
\hline 100 & 381 & 87 & 333 & 6 & 23 & 4 & 15 & 3 & 10 & الإجمالي \\
\hline
\end{tabular}

جدول (5) : تحليل التباين أحادي الاتجاه التحديد معنوية العلاقة بين حجم الموقع والمؤهلات الفنية لمسئولي المنثآت الصناعية الصغيرة

\begin{tabular}{|c|c|c|c|c|c|}
\hline الالالة الإحصائية & $\mathbf{F}$ & التباين المقرر & درجات الحرية & مجموع المربعات & مصادر التباين \\
\hline معنوية & 20,179 & $5,030,183$ & 3 & $15,090,550$ & بين المجموعات \\
\hline & & 249,275 & 16 & $3,938,400$ & داخل المجموعات \\
\hline & & & 19 & $19,078,950$ & التباين الكلي \\
\hline
\end{tabular}

\begin{tabular}{|c|c|c|c|c|c|c|c|c|c|c|}
\hline \multicolumn{2}{|c|}{ الإجمالي } & \multicolumn{2}{|c|}{ خبرة في الصناعة } & \multicolumn{2}{|c|}{ درجة علمية } & \multicolumn{2}{|c|}{ دبلوم } & \multicolumn{2}{|c|}{ دون الدبلوم } & \multirow{2}{*}{ (فئات المدن) } \\
\hline$\%$ & عدد & $\%$ & عدد & $\%$ & عدد & $\%$ & عدد & $\%$ & عدد & \\
\hline 100 & 138 & 7 & 10 & 25 & 35 & 48 & 66 & 20 & 27 & فئة - 1 \\
\hline 100 & $\begin{array}{l}79 \\
\end{array}$ & 10 & 8 & 23 & 18 & 36 & 36 & 22 & 17 & فئة - 2 \\
\hline 100 & 70 & 11 & 8 & 20 & 14 & 43 & 30 & 26 & 18 & فئة - 3 \\
\hline 100 & 43 & 7 & 3 & 33 & 14 & 33 & 14 & 28 & 12 & فئة - 4 \\
\hline 100 & 51 & 6 & 3 & 16 & 8 & 31 & 16 & 47 & 14 & فئة - 5 \\
\hline 100 & 381 & 8 & 32 & 23 & 89 & 43 & 162 & 26 & 98 & الإجمالي \\
\hline
\end{tabular}


جدول (7): تحليل التباين أحادي الأتجاه لتحديد معنوية العلاقة بين حجم الموقع والخلفية العائلية لمسئولي المنشآت الصناعية الصغيرة

\begin{tabular}{|c|c|c|c|c|c|}
\hline الالائة الإحصائية & $\mathbf{F}$ & التباين المقدر & درجات الحرية & مجموع المربعات & مصادر التباين \\
\hline \multirow[t]{3}{*}{ معنوية } & 3,846 & 566,850 & 3 & $1,700,550$ & بين المجموعات \\
\hline & & 147,400 & 16 & $2,358,400$ & داخل المجموعات \\
\hline & & & 19 & $4,058,950$ & التباين الكلي \\
\hline
\end{tabular}

\begin{tabular}{|c|c|c|c|c|c|c|c|c|c|c|c|c|}
\hline \multicolumn{13}{|c|}{ جلول (8) : الموقع و الخلفية المهنية لمسئولي المنشآت الصناعية الصغيرة } \\
\hline \multicolumn{2}{|c|}{ 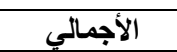 } & & & \multicolumn{2}{|c|}{ 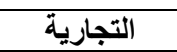 } & \multicolumn{2}{|c|}{ الخدمات" } & \multicolumn{2}{|c|}{ الزراعية } & \multicolumn{2}{|c|}{ الصناعية } & \multirow{2}{*}{ (فئات المدنق) } \\
\hline$\%$ & عدد & $\%$ & عدد & $\%$ & عدد & $\%$ & عدد & $\%$ & عدد & $\%$ & عدد & \\
\hline 100 & 138 & 2 & 3 & 49 & 68 & 11 & 15 & 9 & 13 & 28 & 39 & فئة - 1 \\
\hline 100 & 79 & 5 & 4 & 48 & $\begin{array}{l}38 \\
\end{array}$ & $\overline{10}$ & 8 & $\overline{11}$ & 9 & 25 & 20 & فئة - 2 \\
\hline 100 & 70 & 9 & 6 & 41 & 29 & 13 & 9 & 14 & 10 & 23 & 16 & فئة - 3 \\
\hline 100 & 43 & - & - & 37 & 16 & 7 & 3 & 21 & 9 & 35 & 15 & فَئة - \\
\hline 100 & 51 & 8 & 4 & 37 & 19 & 6 & 3 & 27 & 14 & 22 & 11 & فئة - 5 \\
\hline 100 & 381 & 4 & 17 & 45 & 170 & 10 & 38 & 14 & 55 & 27 & 101 & الإجمالي \\
\hline
\end{tabular}

جدول (9): تحليل التباين أحادي الأتجاه لتحديد معنوية العلاقة بين حجم الموقع والخلفية المهنية لمسئولي المنشآت الصناعية الصغيرة

\begin{tabular}{|c|c|c|c|c|c|}
\hline الدلالة الإحصائية & $\mathbf{F}$ & التباين المقدر & درجات الحرية & مجموع المربعات & مصادر التباين \\
\hline معنوية & 6,258 & 741,340 & 4 & $2,965,360$ & بين المجموعات \\
\hline & & $1,184,600$ & 10 & $2,369,200$ & داخل المجموعات \\
\hline & & & 14 & $5,334,560$ & التباين الكلي \\
\hline
\end{tabular}

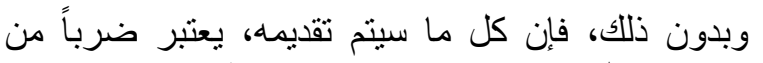

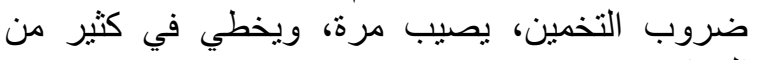

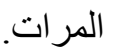

ومن أهم الملامح الهيكلية التي يجب التباتبة التعرف عليها

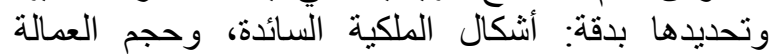

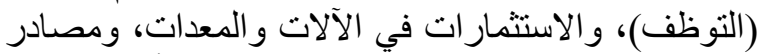

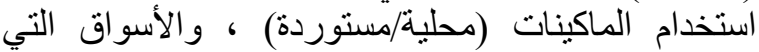

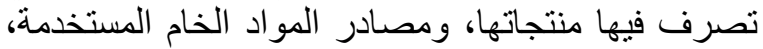

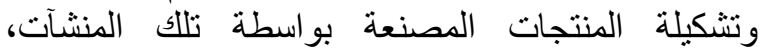
و الإنتفاع بالتسهيلات المتاحة للمنشآت الصناعة الصناعة الصغيرة.

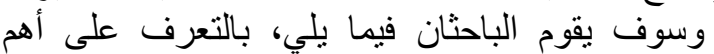

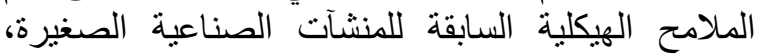
وتحديد العلاقة بينهما وبين حجم الموقع، وذللك في الفئات

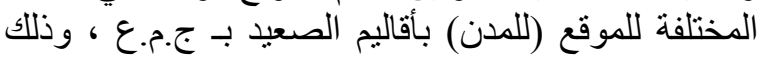

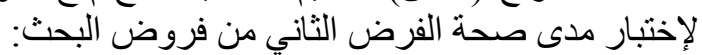
الموقع و أشكال ملكية المنشآت الصناعية الصنية الصنيرة

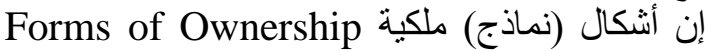
المنشآت الصناعية الصغيرة في الفئات المختلفة للموقع المعادية

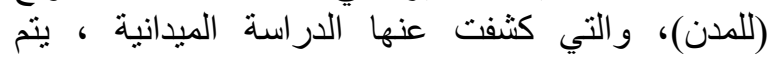
توضيحها من خلال الجدول (10). ومن الجدول السابق، يتضح أن أن هناك فقط شكلين للملكية

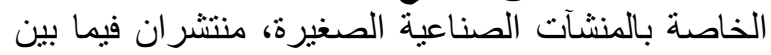

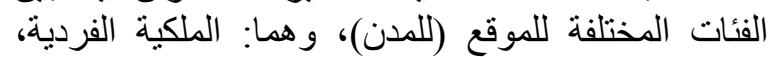
وشركة التضامن. وتحتل الملكية الفردية الترتيب الأولة الفرد

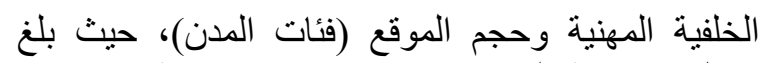

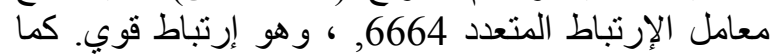

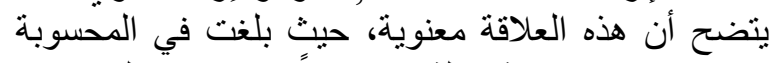
6,258، و وهي قيمة دالة إحصائياً عند كلا المستويين . 0.01 ، 0.05)

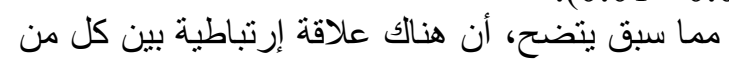
حجم الموقع والخلفية المهنية لمسئولي المنشآت الصناعية المباتية

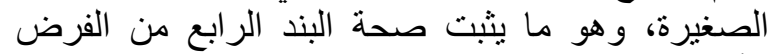
الأول للبحث.

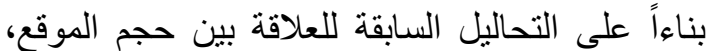

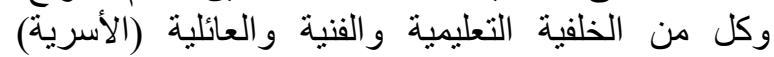

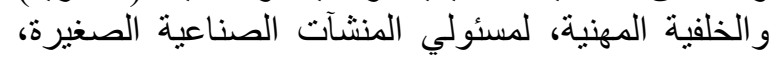
يتضح صحة الفرض الأول من فروضً البحة البحث، ومؤداه

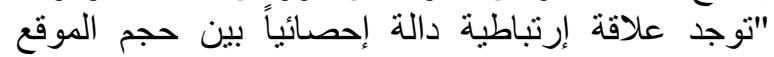
(فئات المدن) وخلفيات مسئولي المنشئآت الصنات الصناعية الصغيرة. بأقاليم الصعيد".

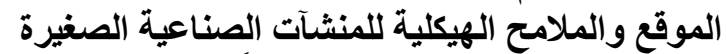

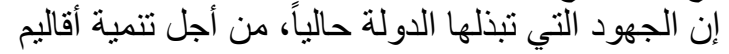

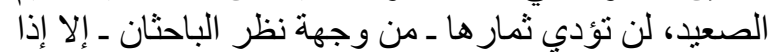

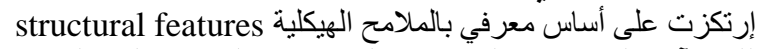

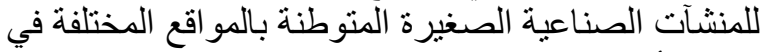

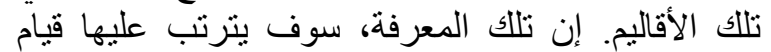

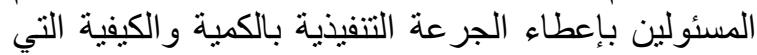
تتلائم مع هيكل الصناعة في كل موقع من تلك المواقع. 
الهيئة العامة للتصنيع، بلغ منوسط عدد العاملين نحو 13 عامل 36 باحث. المان.

- أن 16\% من باحن المنشآت الصناعية الصغيرة ، يعمل بها

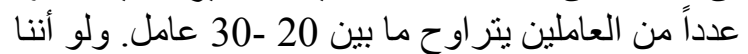

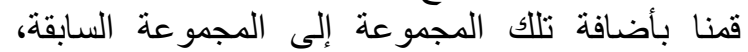

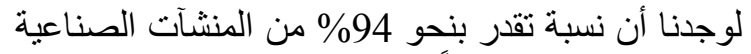

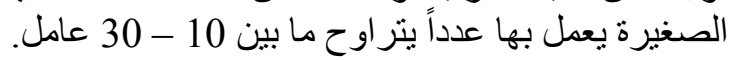

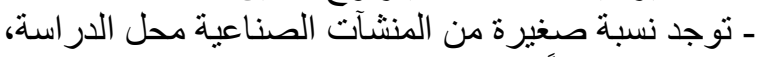

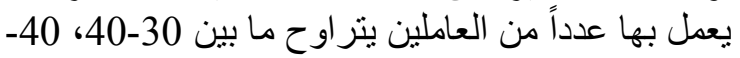

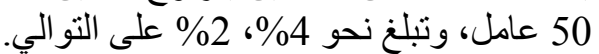

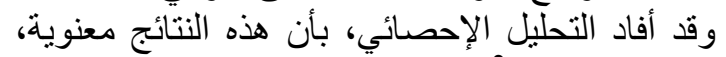
حتى بلغت قيمة كا2 أحصائية عند درجة حرية 3 ومستوى معنوية

ـ أن هناك علاقة عكسية بين نسبة العاملين في المدى 10-

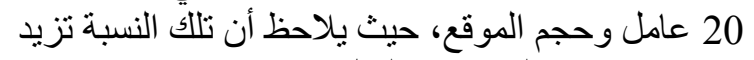

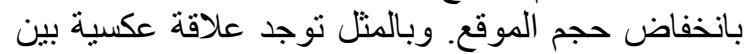

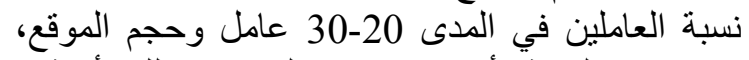

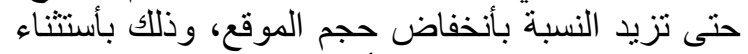

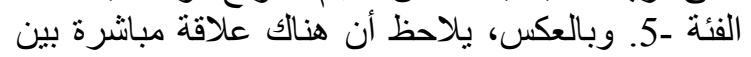

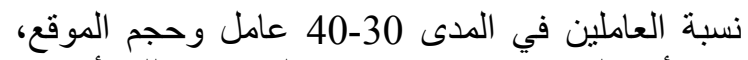

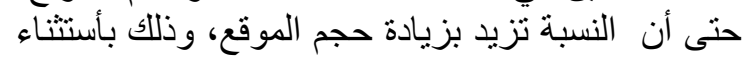

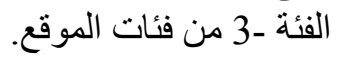
ولتوضيح عما إذا كانت علاقة إرتباطية بين حجم العمالة

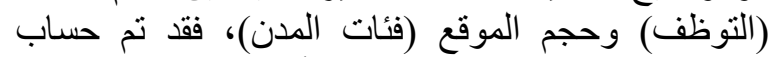

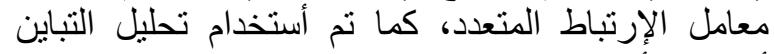

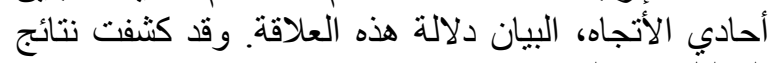
التحليلٌ عما يلي: النياه ويتضح من الجدول السابق أن هناك علاقة إرتباطية بين الماني

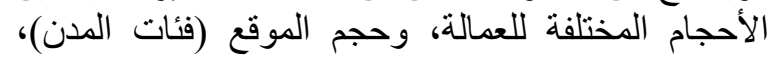
حتى بلغ معامل الإرتباط المتعدد العيالة

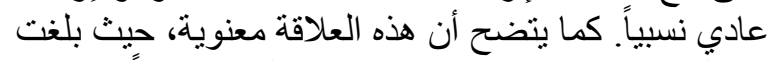

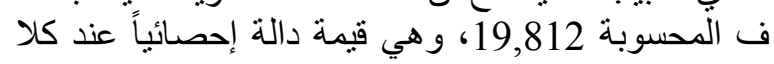
المستويين (0,05 ، 0,01). مما سبق يتضح أن هناك علاقة إرتباطية معنوية بين

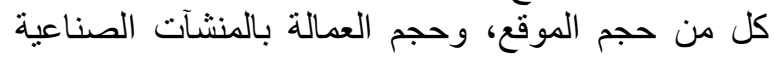

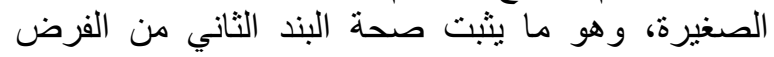

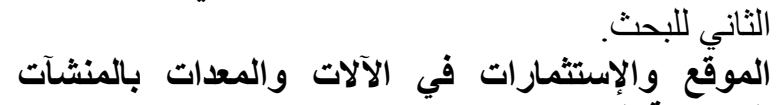
الصناعية الصغيرة الإنئرات بمكن توضيح أحجام الإستثمار ات في الآلات و المعدات

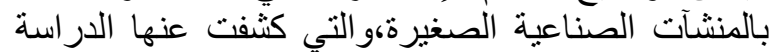
الميدانية، من خلال الجدول (14). ومن الجدول السابق، يتضح ما يلي الئي

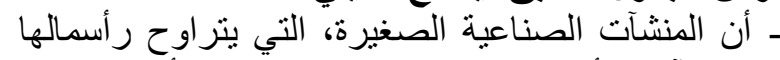

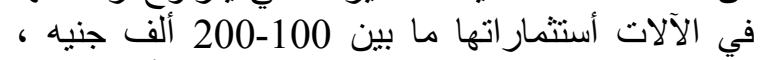

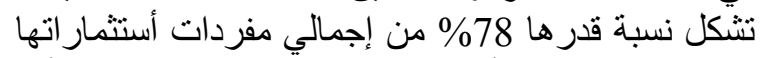

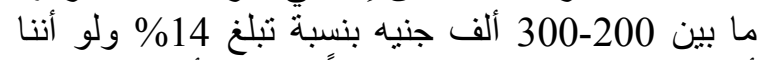
أضفنا المجموعنين السابقتين معاً، لوجدنا أن النسبة تبلغ
بنسبة 71\%، ثم شركة التضامن في المركز الثاني بنسبة

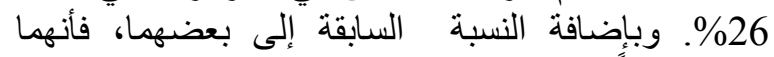

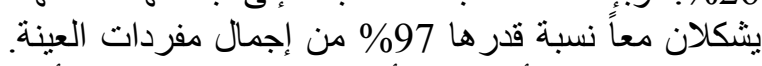

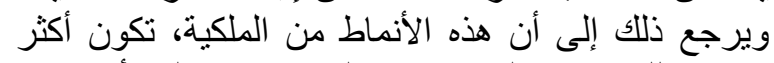

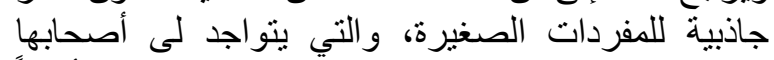

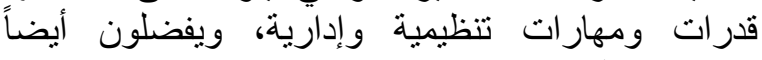
الإشر اف على إستثمار اتهم 35 باحثة .

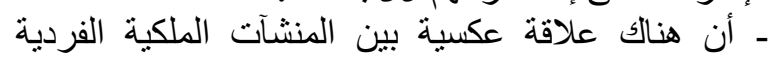

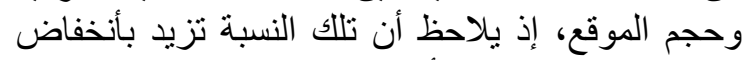

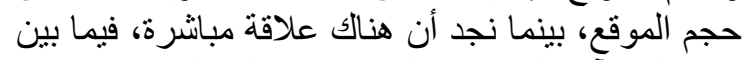

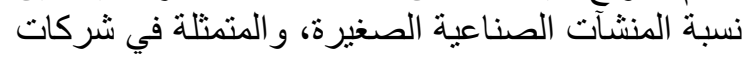

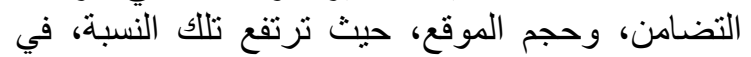

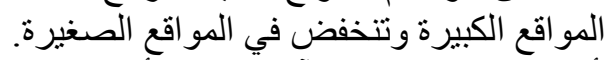

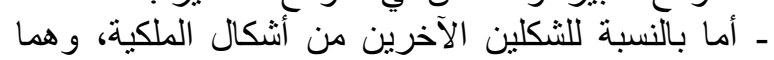

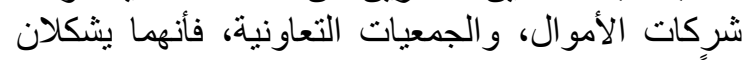

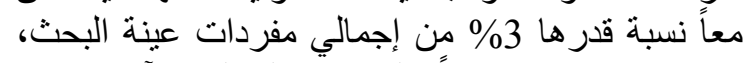

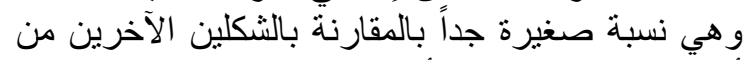

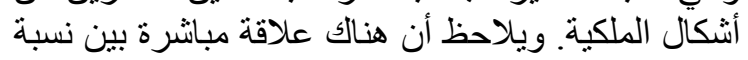

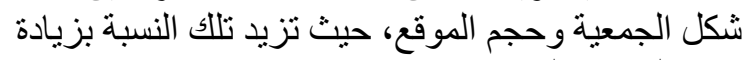
حجم الموقع (المدن). وقد أفاد التحليل الإحصائي ، بأن هذأن هذه النتائج معنوية،

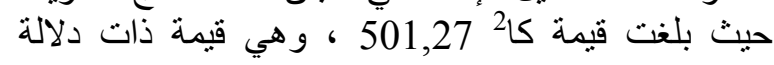

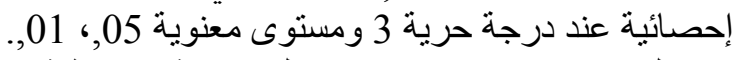

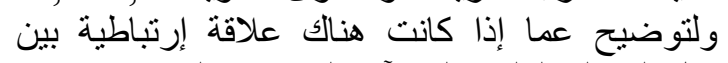

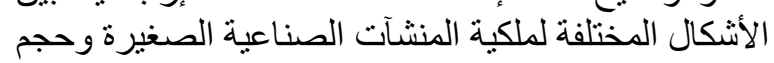

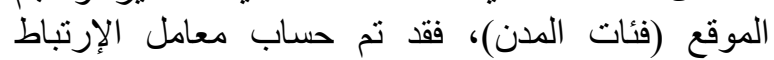

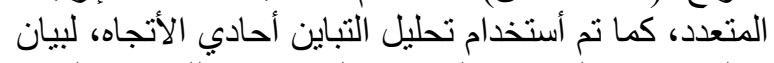

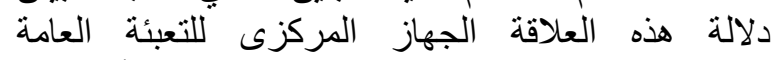

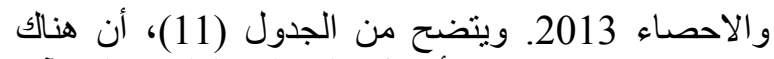
علاقة إرتباطية بين الأشكال المختلفة لملكية المنشآت المنات المناك

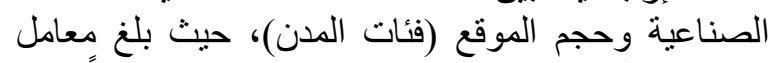

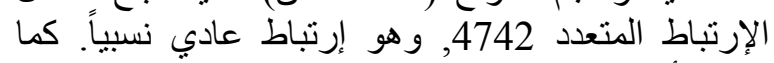

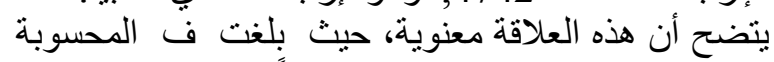
11,230، وهي قان هيمة دالة إحصائياً عند كلا المستويين

. (0,01 ، 0,05)

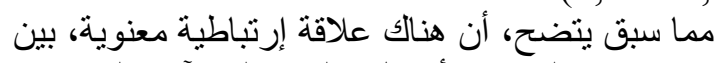

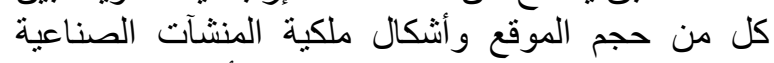

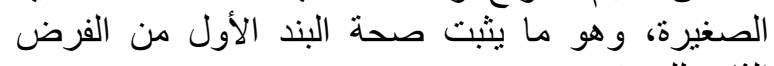
الموقيع للبحثم المجثم العمالة (التوظف) بالمنشآت الصناعية الصغيرة إن حجم (نماذج) العمالة Employment بالمنشة المنآت

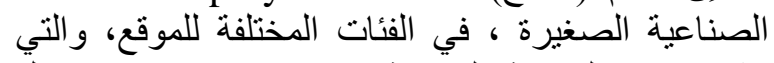
كثفت عنه الدراسة الميدانية، يمكن نوضيحهات من خلال

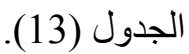
ومن الجدول السابق، يتضح أن نسبة 78\% من المنشآت

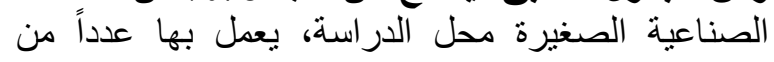

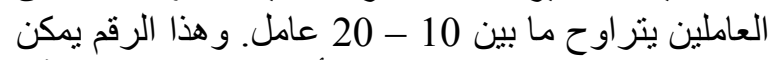

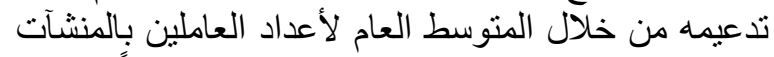
الصناعية الصغيرة على المستوى القومي، وطبقاً لبيانات 


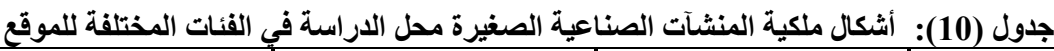

\begin{tabular}{|c|c|c|c|c|c|c|c|c|c|c|}
\hline \multicolumn{2}{|c|}{ الإجمالي } & \multicolumn{2}{|c|}{ جمعية تعاونية } & \multicolumn{2}{|c|}{ شركة أموال } & \multicolumn{2}{|c|}{ شركة تضامن } & \multicolumn{2}{|c|}{ ملكية فردية } & \multirow{2}{*}{ (فئات المدن } \\
\hline$\%$ & عدد & $\%$ & عدد & $\%$ & عدد & $\%$ & عدد & $\%$ & عدد & \\
\hline 100 & 138 & 2 & 3 & 1 & 1 & 34 & 47 & 63 & 87 & فئة - 1 \\
\hline 100 & 79 & 3 & 2 & - & - & 32 & 25 & 66 & 52 & فئة - 2 \\
\hline 100 & 70 & - & - & 1 & 1 & 26 & 18 & 73 & 51 & فئة - 3 \\
\hline 100 & 43 & 2 & 1 & - & - & 19 & 8 & 79 & 34 & فئة - 4 \\
\hline 100 & 51 & 2 & 1 & - & - & 4 & 2 & 94 & 48 & فئة - 5 \\
\hline 100 & 381 & 2 & 7 & 1 & 1 & 26 & 100 & 71 & 272 & الإجمالي \\
\hline
\end{tabular}

جدول (11) : تحليل التباين أحادي الأتجاه لتحديد معنوية العلاقة بين حجم الموقع وأشكال ملكية المنشآت الصناعية الصغيرة

\begin{tabular}{|c|c|c|c|c|c|}
\hline الدلالة الإحصائية & $\mathbf{F}$ & التباين المقدر & درجات الحرية & مجموع المربعات & مصادر التباين \\
\hline معنوية & 11,230 & $1,486,850$ & 3 & $4,460,550$ & بين المجموعات \\
\hline & & 132,400 & 16 & $2,118,400$ & داخل المجموعات \\
\hline & & & 19 & $6,578,950$ & التباين الكلي \\
\hline
\end{tabular}

جدول (12): حجم العمالة بالمنشآت الصناعية الصغيرة محل الدراسة في الفئات المختلفة للموقع

\begin{tabular}{|c|c|c|c|c|c|c|c|c|c|c|}
\hline & & \multicolumn{8}{|c|}{ أعداد العمالة الفعلية } & \multirow{3}{*}{ (فئات المدن) } \\
\hline \multicolumn{2}{|c|}{ الإجمالي } & \multicolumn{2}{|c|}{$50-40$} & \multicolumn{2}{|c|}{$40-30$} & \multicolumn{2}{|c|}{$30-20$} & \multicolumn{2}{|c|}{ |كتوبر-20 } & \\
\hline$\%$ & عدد & $\%$ & عدد & $\%$ & عدد & $\%$ & عدد & $\%$ & عدد & \\
\hline 100 & 138 & 3 & 4 & 7 & 10 & 15 & 21 & 75 & 103 & فئة - 1 \\
\hline 100 & 79 & 3 & 2 & 4 & 3 & 16 & 13 & 77 & 61 & فئة ـ 2 \\
\hline 100 & 70 & 1 & 1 & 1 & 1 & 19 & 8 & 79 & 55 & فئة - 3 \\
\hline 100 & 43 & - & - & 2 & 1 & 19 & & 79 & 34 & فئة - 4 \\
\hline 100 & 51 & - & - & 2 & 1 & 12 & 6 & 86 & 44 & فئة - 5 \\
\hline 100 & 381 & 2 & 7 & 4 & 16 & 16 & 61 & 78 & 297 & الإجمالي \\
\hline
\end{tabular}

المصدر: إستمارة الإستبيان.

جدول (13): تحليل التباين أحادي الأتجاه لتحديد معنوية العلاقة بين حجم الموقع وحجم العمالة بالمنشآت الصناعية الصفيرة

\begin{tabular}{|c|c|c|c|c|c|}
\hline الدلالة الإحصائية & $\mathbf{F}$ & التباين المقدر & درجات الحرية & مجموع المربعات & مصادر التباين \\
\hline \multirow[t]{3}{*}{ معنوية } & 19,812 & 3729,65 & 3 & 11188,95 & بين المجموعات \\
\hline & & 188,25 & 16 & 3012,00 & داخل المجموعات \\
\hline & & & 19 & 14200,95 & التباين الكلي \\
\hline
\end{tabular}

جدول (14): الاستثمارات في الآلات والمعدات بالمنشآت الصناعية الصغيرة محل الدراسة في الفئات المختلفة للموقع

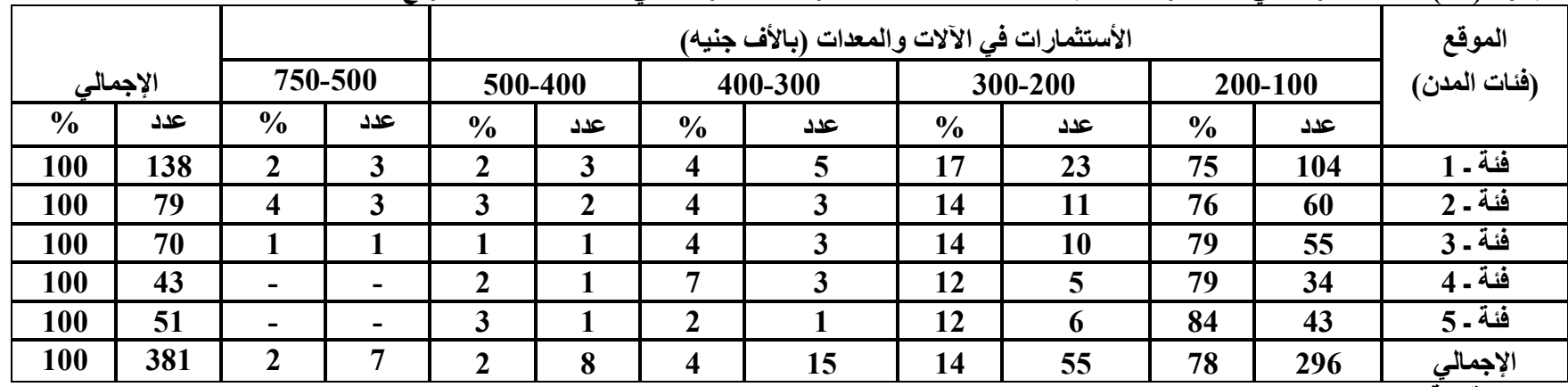


الصغيرة، والتي كثفت عنها الدراسة الميدانية وزارة

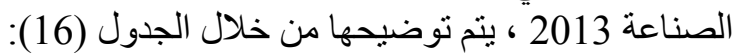

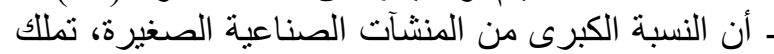
ماكينات محلية (وطنية)، وتبلغ تلاتك النسبة 91\%

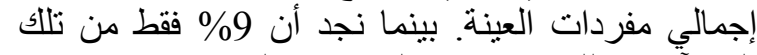

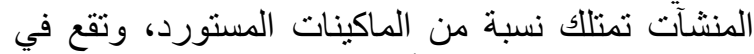

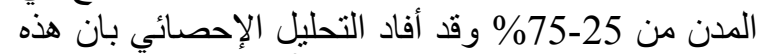

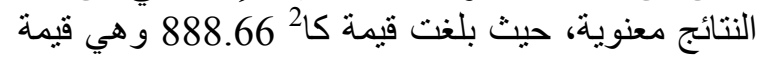
ذات دلالة إحصائية عند درجة حرية 3 ومستوى معنوية . 0.01 0.05 0.05 ـ ل ال توجد أية علاقة بين حجم الموقع واستخدام الماكينات المحلية أو المستوردة، حيث حجث أن أنشكال الأستخدام

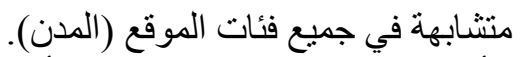

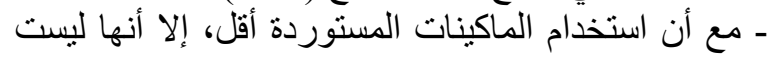

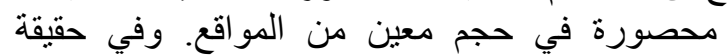
الأمر، فأنه توجد في صناعات معينة في الفئات الّين الصغيرة

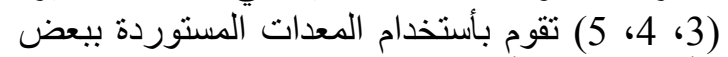

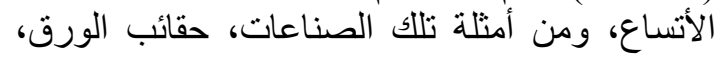

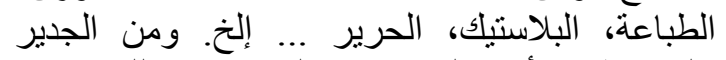

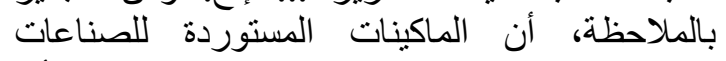

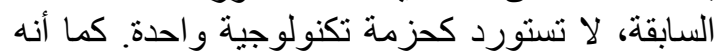

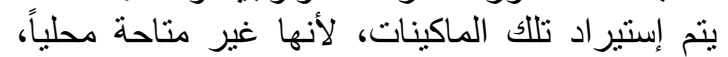

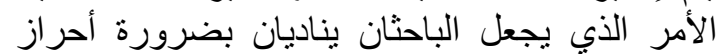

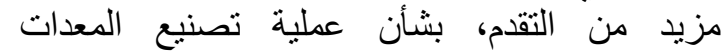
الاستثمارية في ج.م.ع.

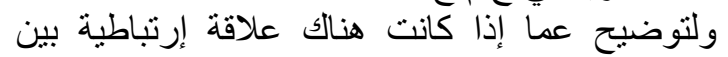

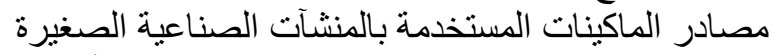

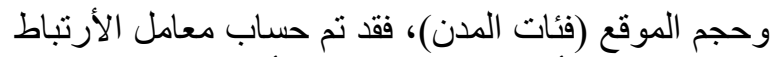

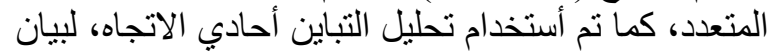

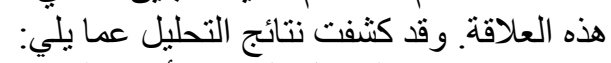

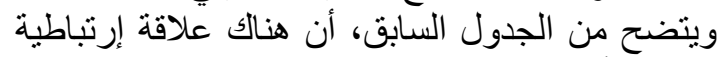

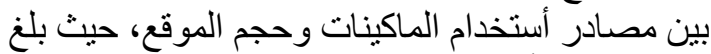

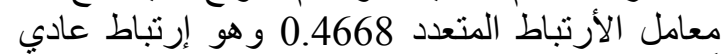

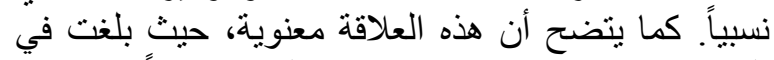

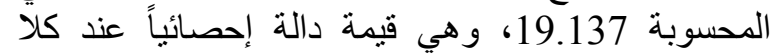

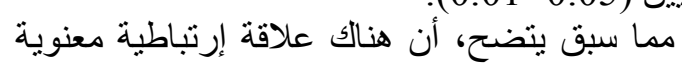

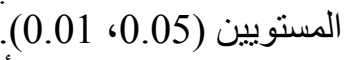

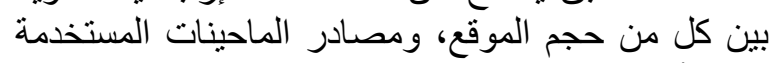

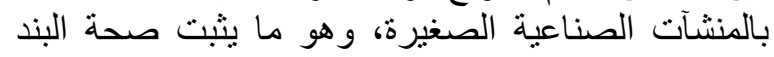

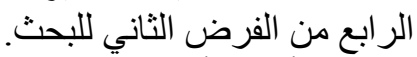
الموقع وأحجام أسواق المنشآت الصناعية الصنية الصنيرة

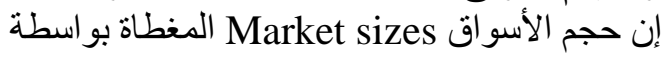

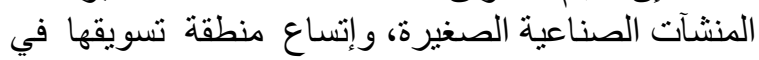

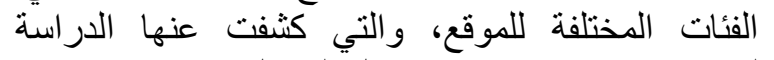

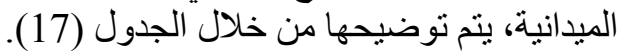
- إن النسبة الأكبر من المنشآت الصناعة الصناعية الصغيرة)

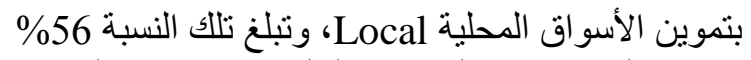

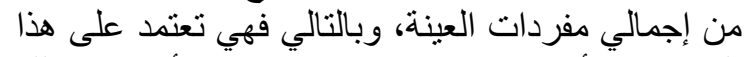

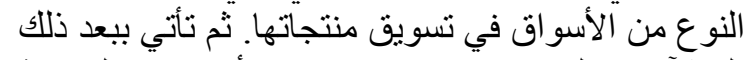

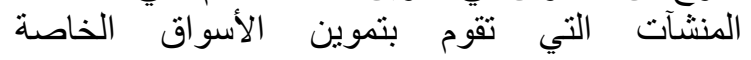

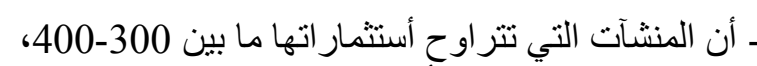

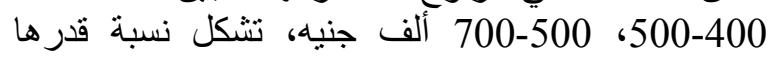

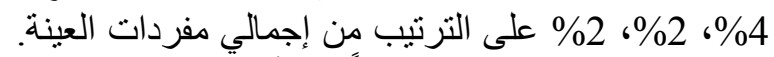

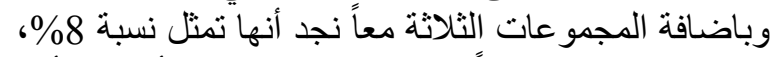

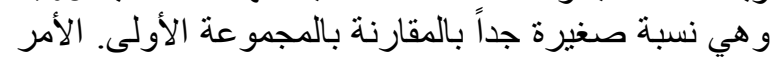

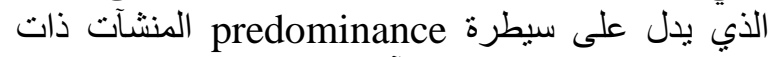
الإستثمار ات الصغيرة في الآلات و المعدات و التي تنر اوح

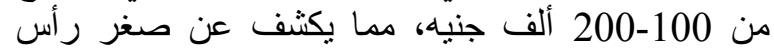
المال الخاص بالمنشآت الصناعية الصغيرة.

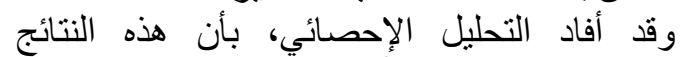

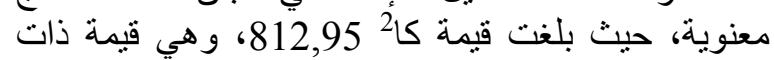
دلالة إحصائية عند درجة حرية 4، ومستوى معنوية 0.01 0.05 0.05 - أما بالنسبة للعلاقة بين الأستثمارات في الآلات

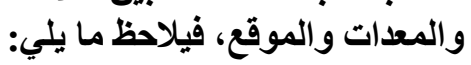

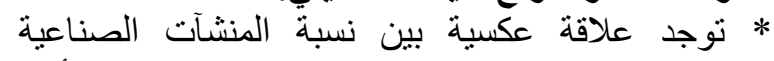

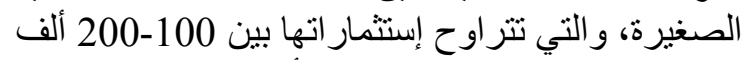

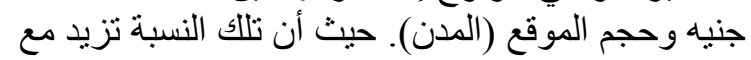
إنخفاض حجم الموقع.

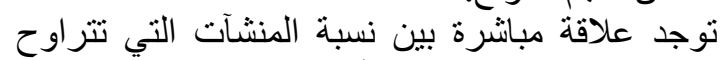

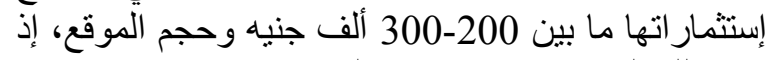
تزيد تلك النسبة مع زيادة حجم الموقع.

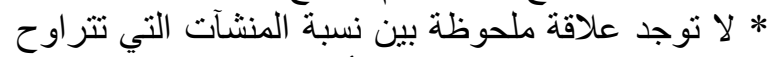

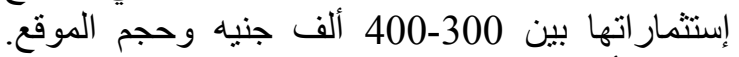

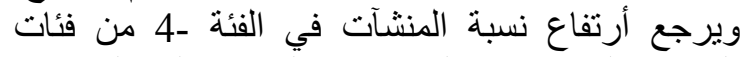

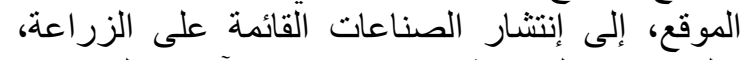

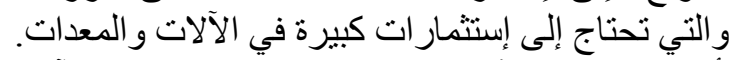

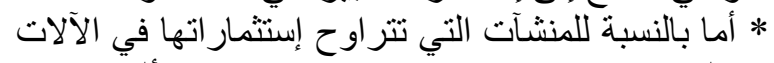

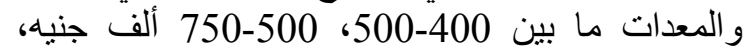

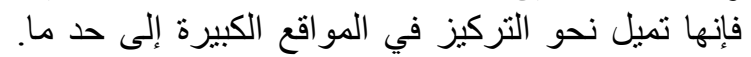

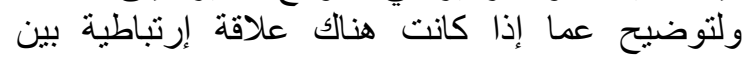

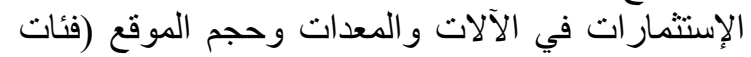

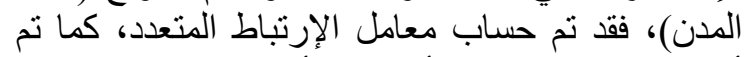

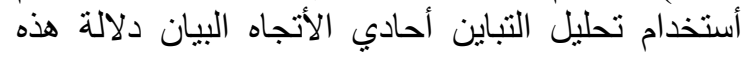

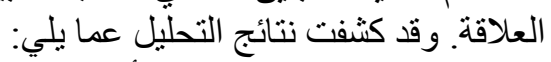
ويتضح من الجدول السابق، أن هنالك علئ علاقة إرتباطية

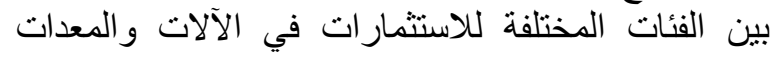

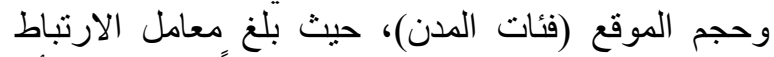

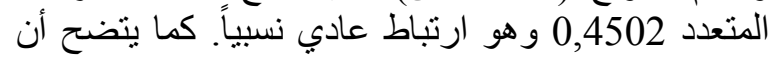

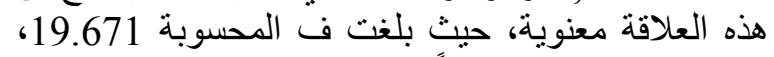
و هي قيمة دالة إحصائياً عند كلا المستويين (0.05 ،

مما سبق يتضح أن هناك علاقة إرتباطية معنوية،

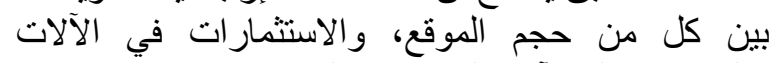

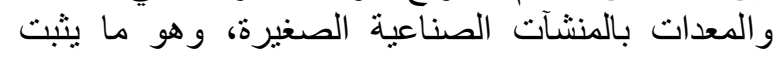

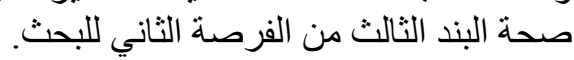

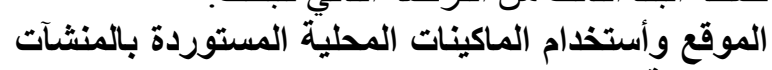
الصناعية الصغيرة

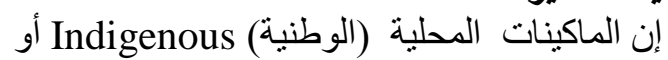
المستوردة Imported بواسطة المنشآت الصنات الصناعية 


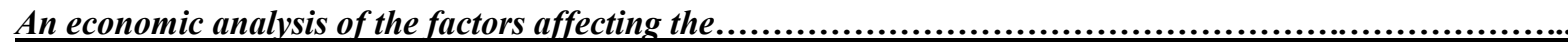

جدول (15) : تحليل التباين أحادي الإتجاه لتحديد معنوية العلاقة بين حجم الموقع والاستثمارات في الآلات والمعدات بالمنشآت الصناعية الصغيرة

\begin{tabular}{|c|c|c|c|c|c|}
\hline الالالة الإحصائية & $\mathbf{F}$ & التباين المقرر & درجات الحرية & مجموع المربعات & مصادر التباين \\
\hline معنوية & 19,671 & $3,097,340$ & 4 & $12,389,360$ & بين المجموعات \\
\hline & & 157,460 & 20 & $3,149,200$ & داخل المجموعات \\
\hline & & & 24 & $15,538,560$ & التباين الكلي \\
\hline
\end{tabular}

\begin{tabular}{|c|c|c|c|c|c|c|c|c|c|c|}
\hline \multirow{2}{*}{\multicolumn{2}{|c|}{ الإجمالي }} & \multicolumn{8}{|c|}{ نسبة الماكينات المحلية (الوطنية) المستخدمة } & \multirow{3}{*}{ الموقع فئات } \\
\hline & & \multicolumn{2}{|c|}{$\% 100-75$} & \multicolumn{2}{|c|}{$\% 75-50$} & \multicolumn{2}{|c|}{$\% 50-25$} & \multicolumn{2}{|c|}{ أقلّ من 25\% } & \\
\hline$\%$ & عدد & $\%$ & عدد & $\%$ & عدد & $\%$ & عدد & $\%$ & عدد & \\
\hline 100 & 138 & 91 & 126 & 4 & 6 & 2 & 3 & 2 & 3 & فئذة - 1 \\
\hline 100 & 79 & 91 & 72 & 5 & 4 & 3 & 2 & 1 & 1 & فئة - 2 \\
\hline 100 & 70 & 90 & 63 & 9 & 6 & - & - & 1 & 1 & فئة - 3 \\
\hline 100 & 43 & 88 & 38 & 7 & 3 & 2 & 1 & 2 & 1 & فئة - 4 \\
\hline 100 & 51 & 94 & 48 & 4 & 2 & - & - & 2 & 1 & فئة - 5 \\
\hline 100 & 381 & 91 & 347 & 5 & 21 & 2 & 6 & 2 & 7 & الإجمالي \\
\hline
\end{tabular}

جدول (17): تحليل التباين أحادي الإتجاه لتحديد معنوية العلاقة بين حجم الموقع ومصادر أستخدام الماكينات بالمنشآت الصناعية الصغيرة

\begin{tabular}{|c|c|c|c|c|c|}
\hline الدلالة الإحصائية & $\mathbf{F}$ & التباين المقدر & درجات الحرية & مجموع المربعات & مصادر التباين \\
\hline معنوية & 19,137 & $5,642,983$ & 3 & 16928,95 & بين المجموعات \\
\hline & & 294,875 & 16 & $4,718,000$ & داخل المجموعات \\
\hline & & & 19 & $21,646,950$ & التباين الكلي \\
\hline
\end{tabular}

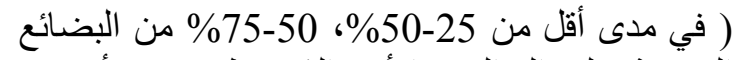

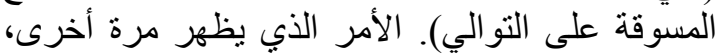

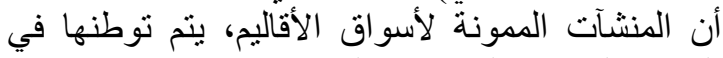

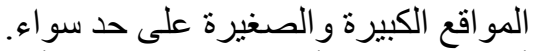

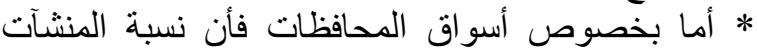

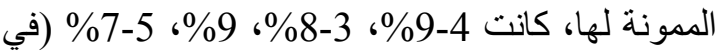

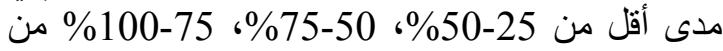

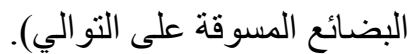

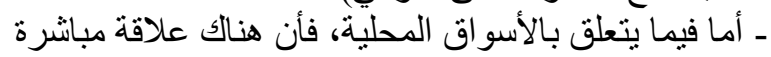

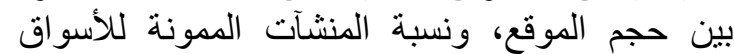

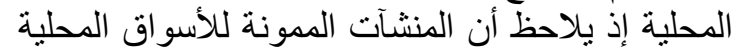

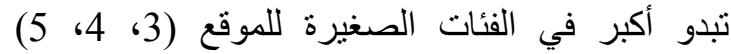
وتتراوح نسبتها بين 29-43\%، بالفينات بالمقارنة بالفئات

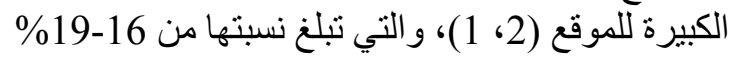

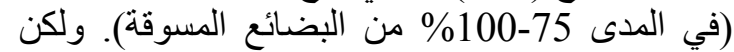
هذا الأتجاه يظهر بوضوح، لو أننا قمنا بدراسة الحبام الحبام

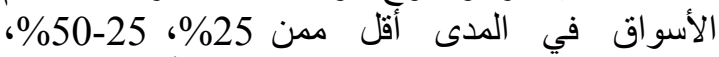

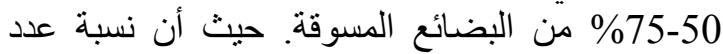

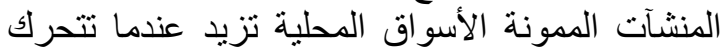

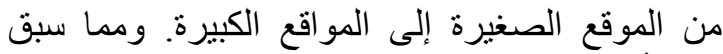

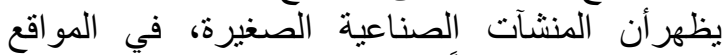

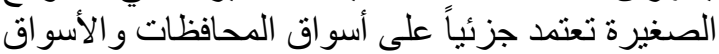

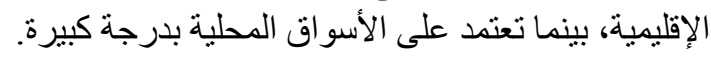

بالمحافظات، وذللك بنسبة قدر ها 25\% بليها الأسواق الإقليمية Regions بنسبة 16\% بينما نجد أن نسبة الإنة

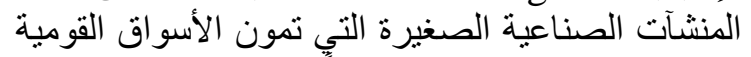

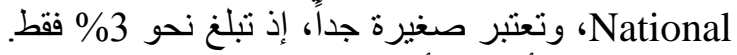

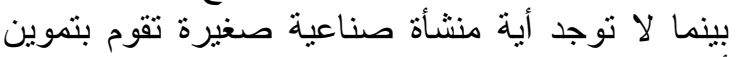

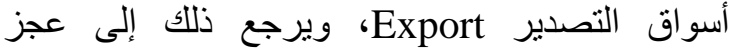

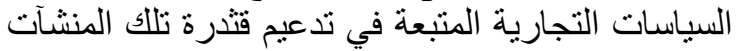

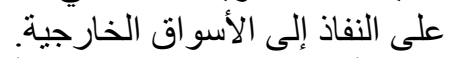
وقد أفاد التحليل الإحصائي، بأن هذه النية النتائج معنوية،

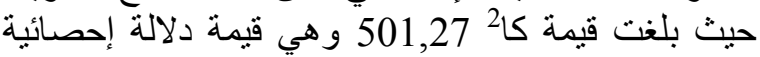
عند درجة حرية 3، ومستوى معنوية كلية 0.05،

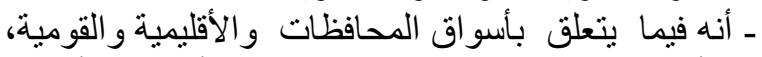

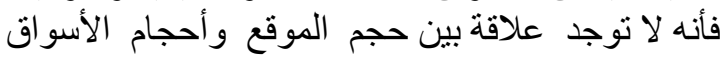

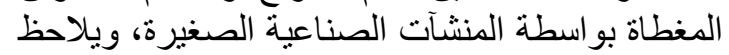
ذلك مما يلي: * إن نسبة المنشآت الممونة للأسواق القومية تتراوح بين

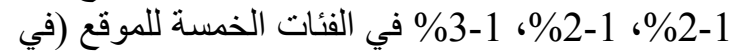

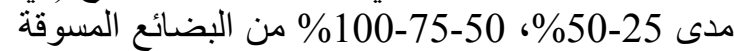

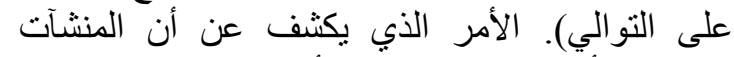

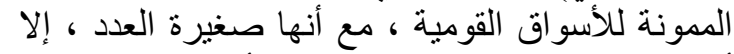

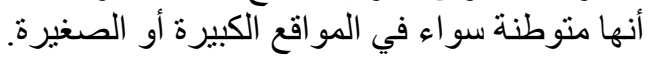
* كذلك ، فإن نسبة المنشآت الصناع الكباعية الصغيرة الصغيرة الممونة لأسواق الأقاليم تمثل 4-6\%؛ 1-4\%، 2-7\%؛ 4-7 \% 
جدول (18) :نسبة المنشآت الصناعية الصغيرة ـ محل الاراسة ـ الممونة للأحجام المتنوعة من الأسواق في الفئات المختلفة للموقع (فئع

\begin{tabular}{|c|c|c|c|c|c|c|c|c|c|c|c|c|}
\hline \multirow{2}{*}{\multicolumn{2}{|c|}{ الإجمالي }} & & & \multicolumn{8}{|c|}{ الموقع (فئات المدن) } & \multirow{3}{*}{ أحجام الأسواق } \\
\hline & & \multicolumn{2}{|c|}{ 5ئة 5ئة } & \multicolumn{2}{|c|}{ فئة -4 } & \multicolumn{2}{|c|}{ فئة -33 } & \multicolumn{2}{|c|}{ فئة -2 } & \multicolumn{2}{|c|}{ فئة -1 } & \\
\hline$\%$ & عدد & $\%$ & عدد & $\%$ & عدد & $\%$ & عدد & $\%$ & عدد & $\%$ & عدد & \\
\hline \multicolumn{13}{|c|}{ أقل من 25\% } \\
\hline 12 & 47 & 8 & 4 & 9 & 4 & 12 & 8 & 13 & 10 & 15 & 21 & سوق محلي \\
\hline 7 & 28 & 4 & 2 & 7 & 3 & 7 & 5 & 8 & 6 & 9 & 12 & سوق محافظة \\
\hline 5 & 19 & 4 & 2 & 5 & 2 & 4 & 3 & 5 & 4 & 6 & 8 & سوق أقليم \\
\hline- & - & - & - & - & - & - & - & - & - & - & - & سوق قومي \\
\hline \multirow[t]{2}{*}{-} & - & - & - & - & - & - & - & - & - & - & - & سوق تصدير \\
\hline & & & & & & & & & & & & $: \% 50-25$ \\
\hline 9 & 34 & 4 & 2 & 5 & 2 & 6 & 4 & 4 & 8 & 13 & 18 & سوق محلي \\
\hline 6 & 21 & 8 & 4 & 7 & 3 & 7 & 5 & 5 & 5 & 3 & 4 & سوق محافظة \\
\hline 2 & 9 & 4 & 2 & 2 & 1 & 3 & 2 & 2 & 1 & 2 & 3 & سوق إقليم \\
\hline 1 & 3 & - & - & 2 & 1 & 2 & 1 & 1 & - & 1 & 1 & سوق قومي \\
\hline \multirow[t]{2}{*}{-} & - & - & - & - & - & - & - & - & - & - & - & سوق تصدير \\
\hline & & & & & & & & & & & & $\% 75-50$ \\
\hline 11 & 41 & 4 & 2 & 5 & 2 & 7 & 5 & 5 & 8 & 17 & 24 & سوق محلي \\
\hline 6 & 24 & 8 & 4 & 7 & 3 & 6 & 4 & 4 & 7 & 4 & 6 & سوق محافظة \\
\hline 4 & 15 & 4 & 2 & 7 & 3 & 4 & 3 & 3 & 4 & 2 & 3 & سوق أقليم \\
\hline 1 & 3 & - & - & - & - & 2 & 1 & 1 & 1 & 1 & 1 & سوق قومي \\
\hline \multirow[t]{2}{*}{-} & - & - & - & - & - & - & - & - & - & - & - & سوق تصدير \\
\hline & & & & & & & & & & & & $\% 100-75$ \\
\hline 24 & 92 & 43 & 22 & 30 & 13 & 29 & 20 & 19 & 15 & 16 & 22 & سوق محلي \\
\hline 6 & 21 & 4 & 2 & 7 & 3 & 4 & 3 & 6 & 5 & 6 & 8 & سوق محافظة \\
\hline 5 & 18 & 4 & 2 & 7 & 3 & 6 & 4 & 4 & 3 & 4 & 6 & سوق أقليم \\
\hline 1 & 5 & 2 & 1 & - & - & 1 & 1 & 3 & 2 & 1 & 1 & سوق قومي \\
\hline- & - & - & - & - & - & - & - & - & - & - & - & سوق تصدير \\
\hline 100 & 381 & 100 & 51 & 100 & 43 & 100 & 70 & 100 & 79 & 100 & 138 & الإجمالي \\
\hline
\end{tabular}

الصغيرة، خلال السنوات الأخيرة، قد ترتب عليها ظهور

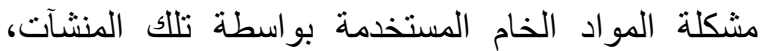

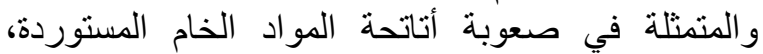

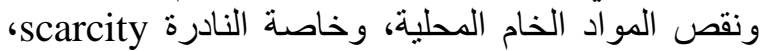

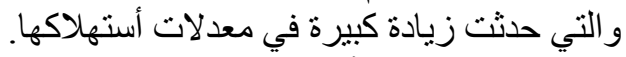

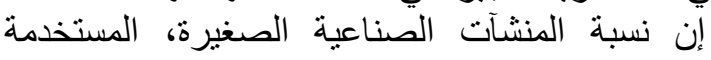

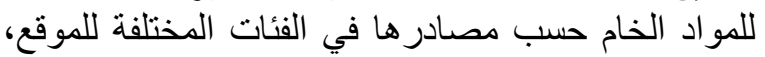

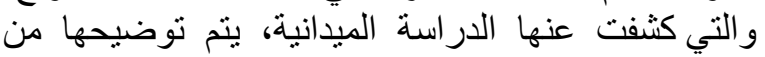

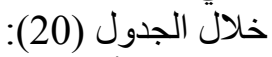
- إن المنشآت الصناعية الصغيرة في الفئات الفئات المختلفة

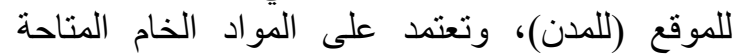

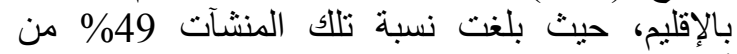

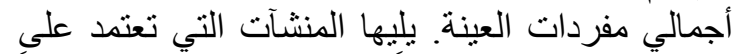

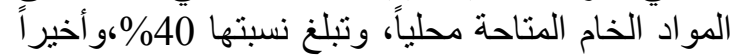

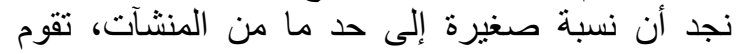

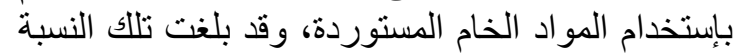
12 12 من أجمالي مفردات العينة. ـ أنه لا نوجد علاقة بين كل من نسبة المنشآت المستخدمة
ولتوضيح عما إذا كانت هناك علاقة إرتباطية بين الأحجام المختلفة لأسواق المنشآت الصنات الصناعية الصغيرة الصنية

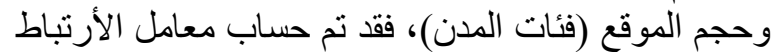
المتعدد، كما تم أستخدام تحليل التباين أحادي الأتجاه، لبيان

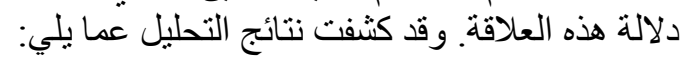
ويتضح من الجدول (19 )، أن هناك الك علاقة إرتباطية

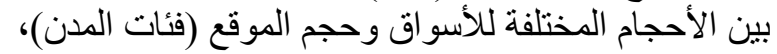
حيث بلغ معامل الإرتباط المعقد

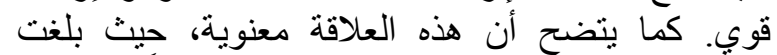
المحسوبة 8566، 8.55، وهي ان هيمة دالة إحصائياً عند كلا المستويين (0.05، 0.01 ). مما سبق يتضح أن هناك علاقة إرتباطية معنوية بين كل

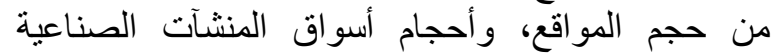

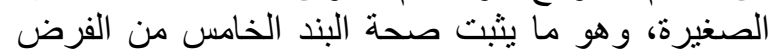

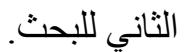
الموقِع ومصادر المواد المواد الخام المستخدمة بالمنشآت الصناعية الصغيرة إن الزيادة السريعة التي حدثت في المنشآت الصناعية 
الخمس للموقع (للمدن) يتم توضيح من خلال الجدول رقم

- إن النسبة الكبرى من المنشآت الصناعية الصغيرة في

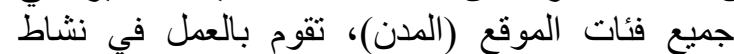
الصناعات الغذائية والمشروبات والثنات والتبغ تلاك في النسبة

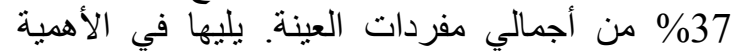

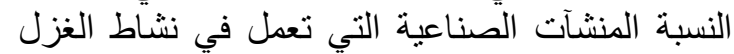

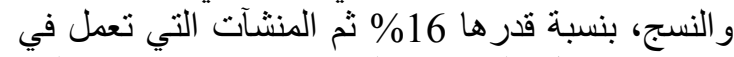

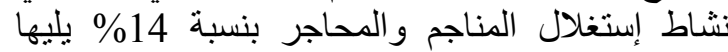

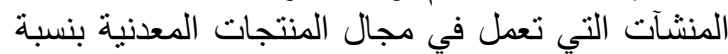

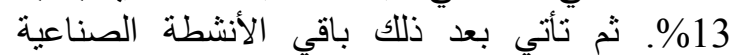

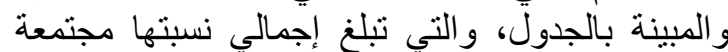

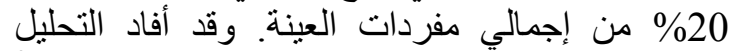

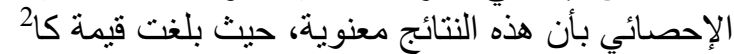
نحو 477.77 وهي قيمة ذات دلالة إحصائية عند درجة حرية 10 ومستوى معنوية ـ ل الوجد ترية أية علاقة فيما بين أي من الأنشطة الصناعية

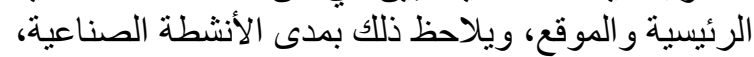

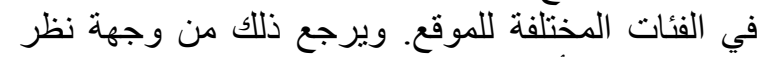

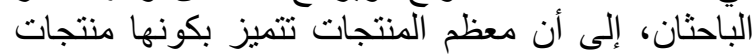

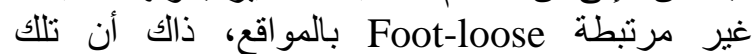

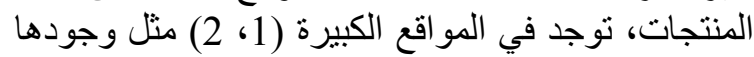

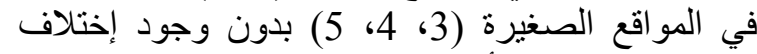

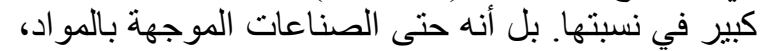

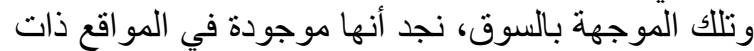
الأحجام المختلفة، بدون وجود إختلاف كبير في نسبنة المباتها، ومن أمثلة تللك الصناعات الغذائية، والنسيج، والطباعة، في النيا، الجلود .... إلخ.

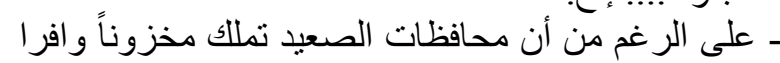

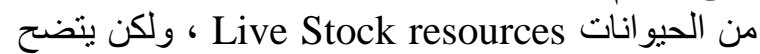
من الجدول، أنه لا يوجد صناعات مرتبطة بالجلود Leather

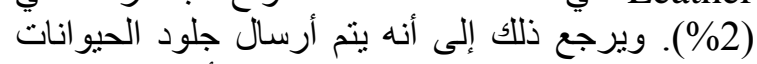

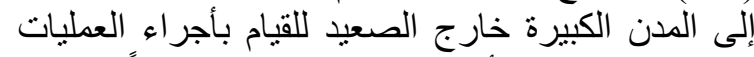

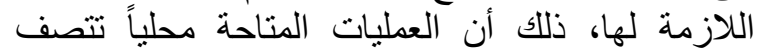

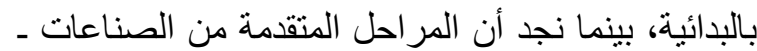

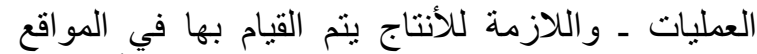

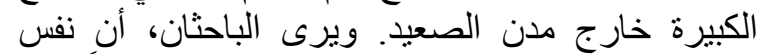

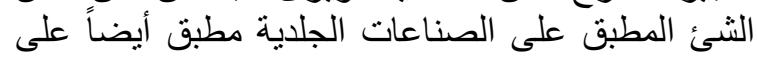

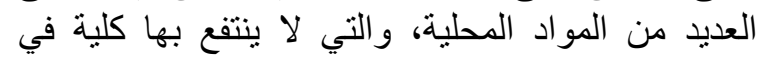

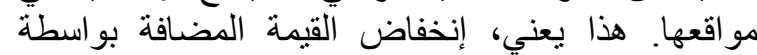

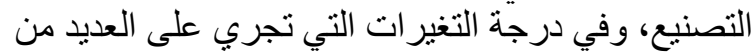
المنتجات التي تصنع تصنع بورة اسطة النيرة المنشآت الصناعية الصنية الصغيرة بأقليم الصعيد.

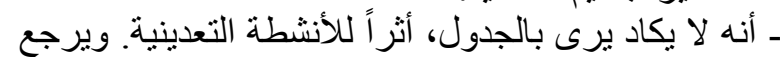
ذللك إلى أن الوضع الأستثماري الر الهن في قطاع التئن التعدين،

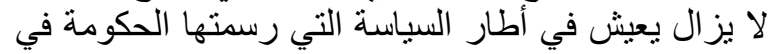

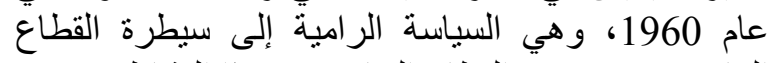

العام، وتهميش دور القطاع الخاص في هذا النئ النشاط.

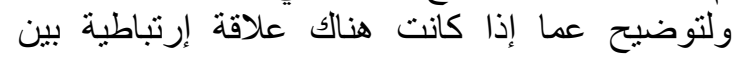

للمو اد الخام حسب مصادر ها الثلاثة (الأقليم، المحلية،

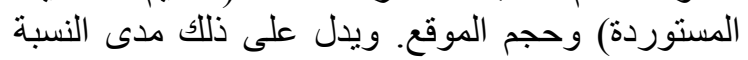

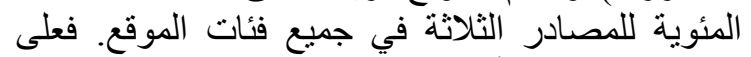

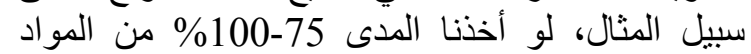

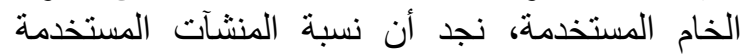

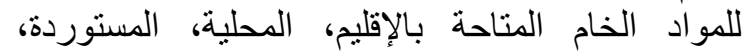

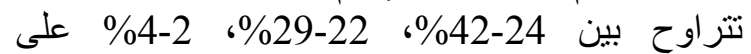

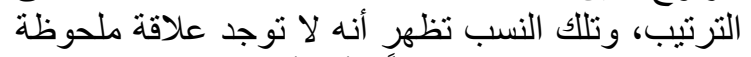

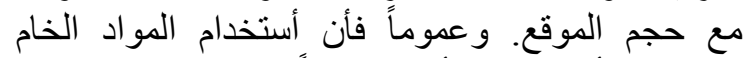

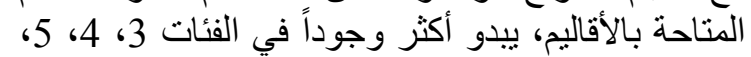

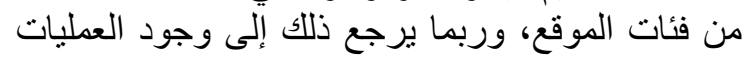

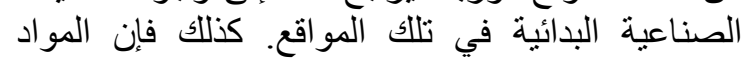

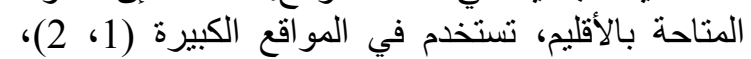

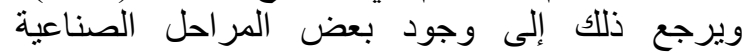

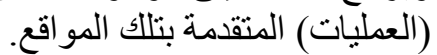

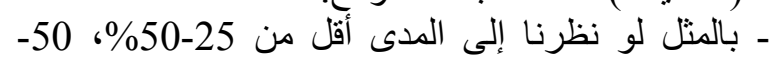

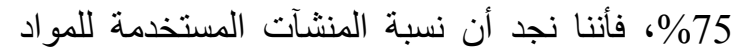
الخام من تللك المصادر الثناثنة (الأقليم، المحلية،

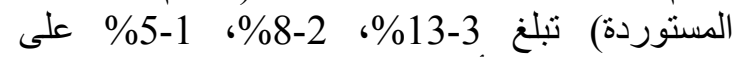

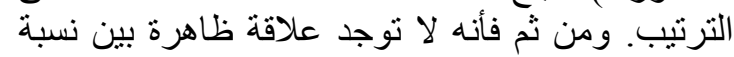

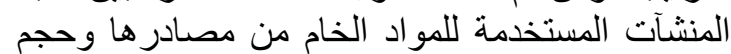

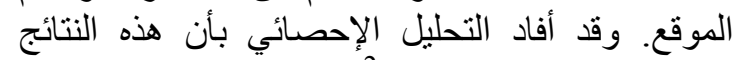

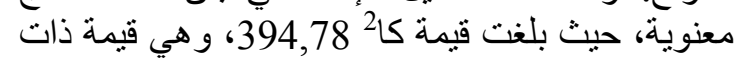
دلالة إحصائية عند درجة حرية 11 ومستوى معنوية 0.01 0.05

ولتوضيح عما إذا كانت هناك علاقة إرتباطية بين

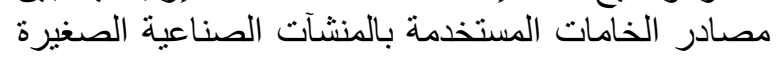

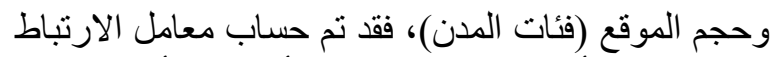

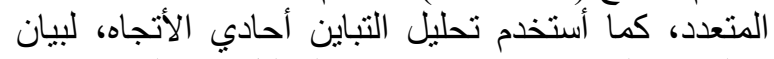

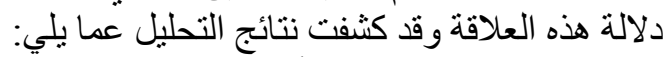

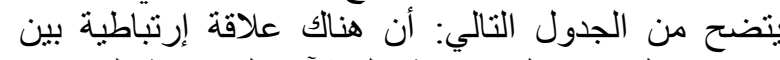

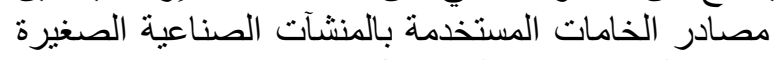

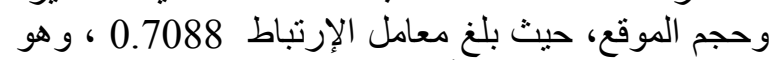

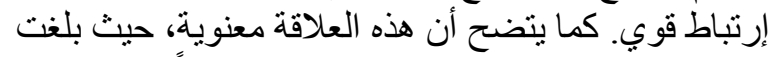

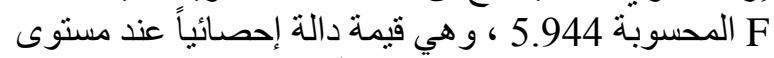

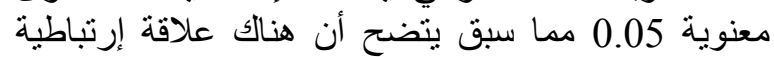

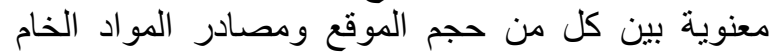

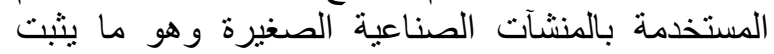
صحة البند السادس من الفرض المنات الثاني للبحث.

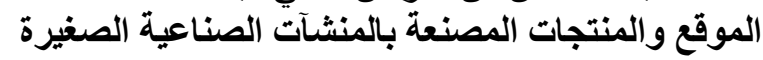

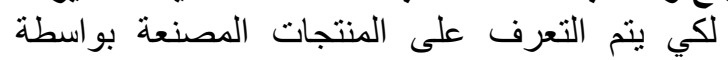

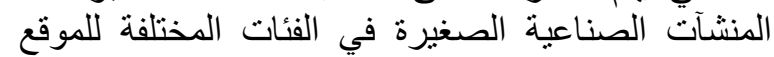

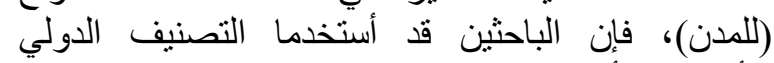

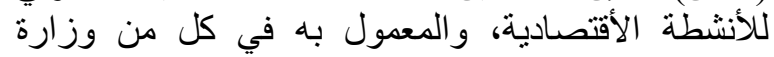

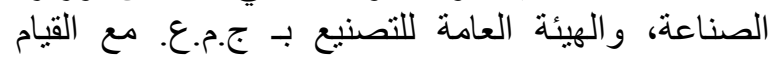

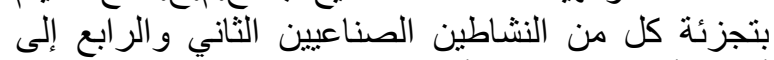

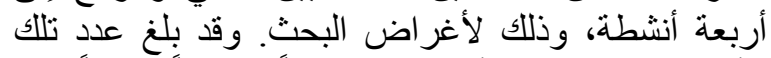

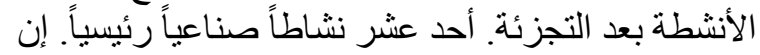
المنشآت الصناعية الصغيرة، التي تدخل الصنّل تحت الأنشطة

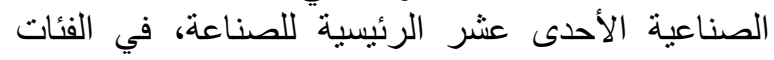




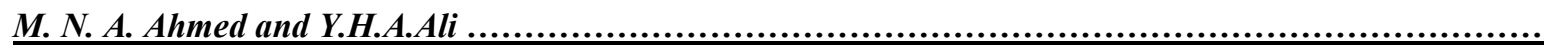

جدول (19) : تحليل التباين أحادي الإتجاه لتحديد معنوية العلاقة بين حجم الموقع وأحجام أسواق المنشآت الصناعية الصغيرة

\begin{tabular}{|c|c|c|c|c|c|}
\hline الالالة الإحصائية & $\mathbf{F}$ & التباين المقدر & درجات الحرية & مجموع المربعات & مصادر التباين \\
\hline معنوية & 8,556 & $1,491,600$ & 3 & $4,474,800$ & بين المجموعات \\
\hline & & 174,325 & 16 & $2,789,200$ & داخل المجموعات \\
\hline & & & 19 & 7264,00 & التباين الكلح \\
\hline
\end{tabular}

جدول (20) : نسبة المنشآت الصناعية الصغيرة ـ محل الدراسة ـ المستخدمة للمواد الخام حسب مصادرها في الفئات المختلفة للموقع (فئع

\begin{tabular}{|c|c|c|c|c|c|c|c|c|c|c|c|c|}
\hline \multirow{2}{*}{\multicolumn{2}{|c|}{ الإجمالبي }} & & & \multicolumn{8}{|c|}{ الموقع (فئات المدن) } & \multirow{3}{*}{ الخام المستخدر المواد } \\
\hline & & \multicolumn{2}{|c|}{ 5-5ئة } & \multicolumn{2}{|c|}{ فئة -4 } & \multicolumn{2}{|c|}{ فئة } & \multicolumn{2}{|c|}{ فئة -20 } & \multicolumn{2}{|c|}{ فئة 1- فئة } & \\
\hline$\%$ & عدد & $\%$ & عدد & $\%$ & عدد & $\%$ & عدد & $\%$ & عدد & $\%$ & عدد & \\
\hline & & & & & & & & & & & & أقلّ من 25\% \\
\hline 9 & 33 & 8 & 4 & 7 & 3 & 7 & 5 & 13 & 10 & 8 & 11 & - الإقَليم \\
\hline 6 & 23 & 4 & 2 & 2 & 1 & 6 & 4 & 6 & 5 & 8 & 11 & ـ المحلية \\
\hline 5 & 18 & 4 & 2 & 5 & 2 & 4 & 3 & 5 & 4 & 5 & 7 & ـ ـ المستوردة \\
\hline & & & & & & & & & & & & $: \% 50-25$ \\
\hline 6 & 22 & 4 & 2 & 5 & 2 & 6 & 4 & 5 & 4 & 7 & 10 & ـ ـ الإقليم \\
\hline 4 & 15 & 4 & 2 & 5 & 2 & 3 & 2 & 3 & 2 & 5 & 7 & ــ المحلية \\
\hline 2 & 8 & - & - & 2 & 1 & 2 & 1 & 4 & 3 & 2 & 3 & ـ ـ المستوردة \\
\hline & & & & & & & & & & & & $\% 75-50$ \\
\hline 5 & 20 & 8 & 4 & 5 & 2 & 6 & 4 & 3 & 2 & 6 & 8 & ـ الإقليم \\
\hline 5 & 20 & 2 & 1 & 2 & 1 & 7 & 5 & 4 & 3 & 7 & 10 & ـ المحلية \\
\hline 2 & 6 & - & - & - & - & 4 & 3 & 3 & 2 & 1 & 1 & ـ المستوردة \\
\hline & & & & & & & & & & & & $\% 100-75$ \\
\hline 29 & 110 & 35 & 18 & 42 & 18 & 30 & 21 & 24 & 19 & 25 & 34 & ــ الإقّليم \\
\hline 25 & 94 & 29 & 15 & 23 & 10 & 24 & 17 & 28 & 22 & 22 & 30 & ـ المحلية \\
\hline 3 & 12 & 2 & 1 & 2 & 1 & 2 & 1 & 4 & 3 & 4 & 6 & ـ المستوردة \\
\hline 100 & 381 & 100 & 51 & 100 & 43 & 100 & 70 & 100 & 79 & 100 & 138 & الإجمالي \\
\hline
\end{tabular}

جدول (21) : تحليل التباين أحادي الإتجاه لتحديد معنوية العلاقة بين حجم الموقع ومصادر الخامات المستخدمة بالمنشآت الصناعية الصغيرة

\begin{tabular}{|c|c|c|c|c|c|}
\hline الدلالة الإحصائية & $\mathbf{F}$ & التباين المقدر & درجات الحرية & مجموع المربعات & مصادر التباين \\
\hline \multirow{3}{*}{ معنوية } & 5,944 & 1087,800 & 2 & 2175,600 & بين المجموعات \\
\hline & & 183,000 & 12 & 2196,000 & داخل المجموعات \\
\hline & & & 14 & 4371,600 & التباين الكلي \\
\hline
\end{tabular}

جدول (22): توزيع المنشآت الصناعية الصغيرة ـ محل الدراسة ـطبقاً للأنشطة الصناعية الرئيسية في الفئات المختلفة للموقع المقات

\begin{tabular}{|c|c|c|c|c|c|c|c|c|c|c|c|c|}
\hline \multirow{2}{*}{\multicolumn{2}{|c|}{ الإجمالي }} & \multicolumn{10}{|c|}{ الموقع (فئات المدن) } & \multirow{3}{*}{ الأنثطة الصناعية الرئيسية } \\
\hline & & \multicolumn{2}{|c|}{ 5-5ئة } & \multicolumn{2}{|c|}{ فئة -4 } & \multicolumn{2}{|c|}{ فئة -3 } & \multicolumn{2}{|c|}{ 2- فئة } & \multicolumn{2}{|c|}{ فئة -1- } & \\
\hline$\%$ & عدد & $\%$ & عدد & $\%$ & عدد & $\%$ & عدد & $\%$ & عدد & $\%$ & عدد & \\
\hline 37 & 140 & 41 & 21 & 33 & 14 & 39 & 27 & 42 & 33 & 33 & 45 & الغذائية والمشروبات والتبغ \\
\hline 16 & 61 & 16 & 8 & 19 & 8 & 19 & 13 & 14 & 11 & 15 & 21 & الغزل والنسيج \\
\hline 6 & 22 & 6 & 3 & 7 & 3 & 4 & 3 & 15 & 4 & 7 & 9 & مواد البناء \\
\hline 13 & 51 & 14 & 7 & 12 & 5 & 13 & 9 & 11 & 9 & 15 & 21 & المنتجات المعدنية \\
\hline 14 & 53 & 14 & 7 & 14 & 6 & 13 & 9 & 16 & 13 & 13 & 18 & إستغلال المناجم والمحاجر \\
\hline 2 & 9 & 2 & 1 & 2 & 1 & 3 & 2 & 1 & 1 & 3 & 4 & الكيماويات الأسناسية ومنتجاتها \\
\hline 3 & 10 & 4 & 2 & 2 & 1 & 3 & 2 & 3 & 2 & 2 & 3 & الخشب ومنتجاته \\
\hline 3 & 12 & 4 & 2 & 2 & 1 & 1 & 1 & 3 & 2 & 4 & 6 & الطباعة والنشر \\
\hline 3 & 12 & - & - & 5 & 2 & 4 & 3 & 4 & 3 & 3 & 4 & الورق والمنتجات الورقية \\
\hline 2 & 6 & - & - & 2 & 1 & - & - & 1 & 1 & 3 & 4 & الجلود ومنتجاتها \\
\hline 1 & 5 & - & - & 2 & 1 & 1 & 1 & - & - & 2 & 3 & الزجاج والمنتجات الزجاجية \\
\hline 100 & 381 & 100 & 51 & 100 & 43 & 100 & 70 & 100 & 79 & 100 & 138 & الأجمالي \\
\hline
\end{tabular}


الصعوبة بمكان حالياً، إلا إذا تم تنشيط وتشجيع قيام

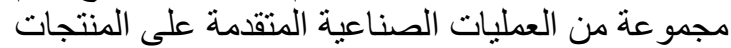
في تللك المو اقع. ـ أما فيما يتعلق بالإنتفاع بالمو اد الخام المستوردة، فنجد أن

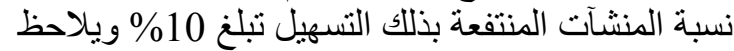
وجود علاقة طردية بين الاتنفاع بالموات التواد الخام

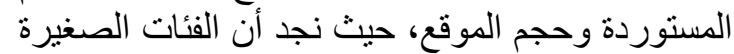

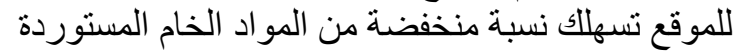

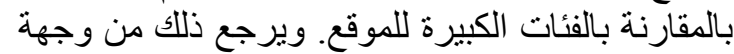

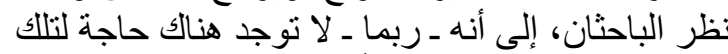

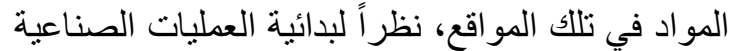

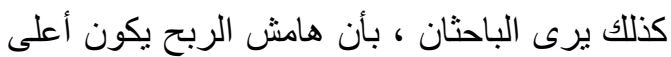

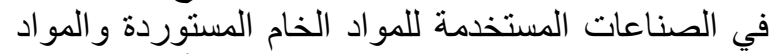

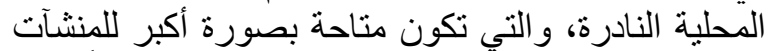

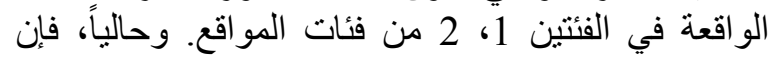
هناك عدد كبير من مسئولي المنشآت الصنات الصناعية الصغيرة،

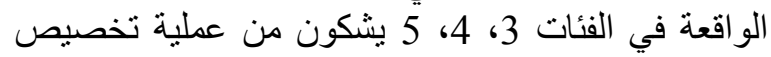

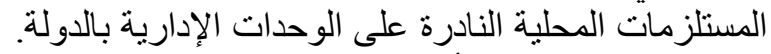

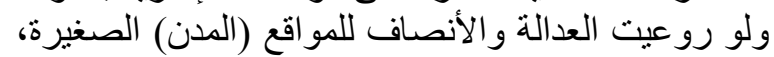
فأن ذلك ربما يساعد في تغيير ، وأعادة ترنيب هيكل الليكل

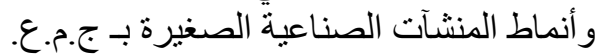
- وبخصوص الإنتفاع بالقروض من تعاونيات التئن التمويل

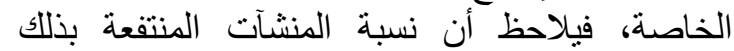

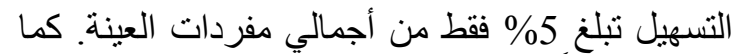

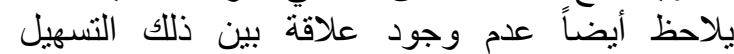

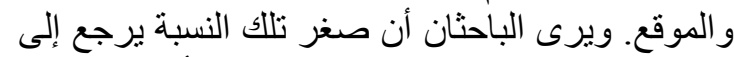

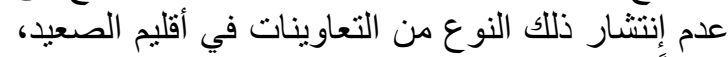

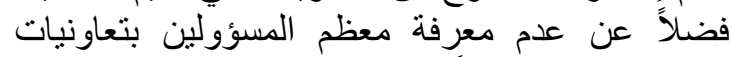
التمويل المتاحة أصلاً. - أما فيما يختص بأستئجار الماكينات، فنجد أن نسبة

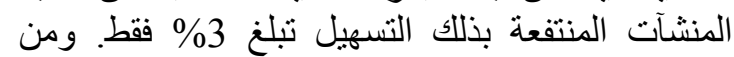

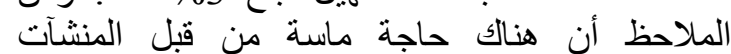
الصناعية الصغيرة في مختلف فئات الموقع إلى إنتشار

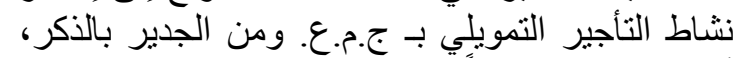

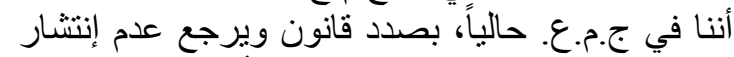

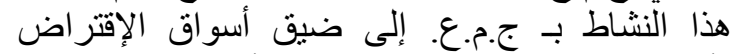

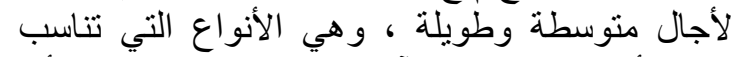

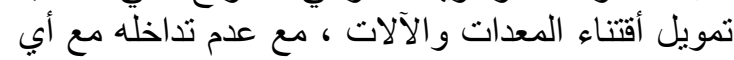
نوع آخر من القروض. المعدات - إن نسبة المنشآت المنتفعة بالتسهيلات الأخرى مثل:

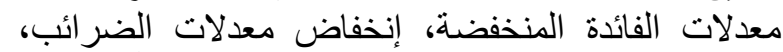

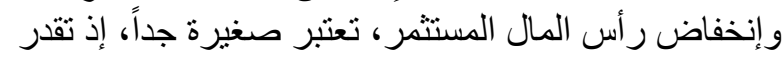

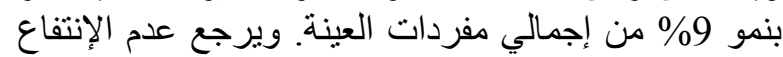

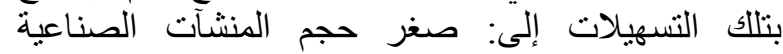

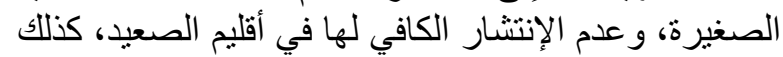

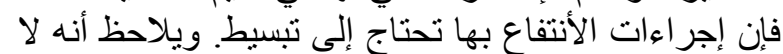

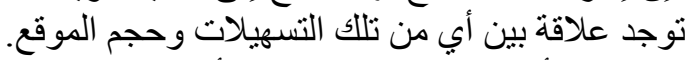

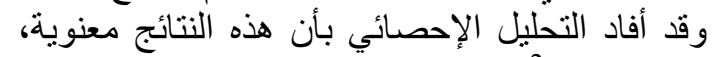

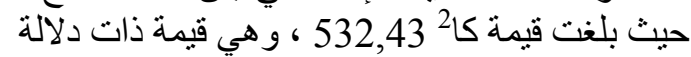

الأشكال المختلفة للمنتجات المصنعة بالمنشآت الصناعية

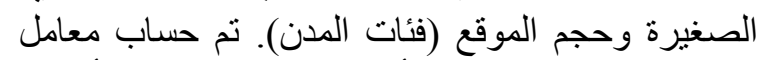

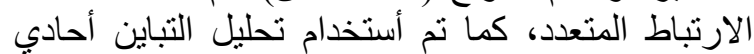
الاتجاه لبيان دلالة هذه العلاقة وقد كثفت نتائج التحليل

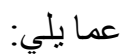
بتضخح من الجدول (23)، أن هناك علاقة إرتباطية بين

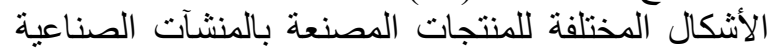

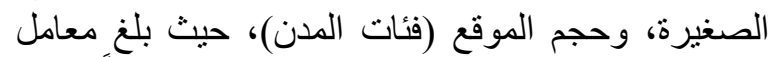

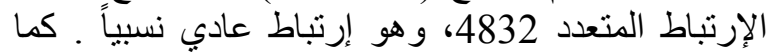

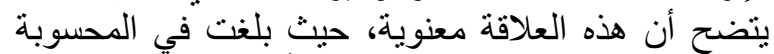

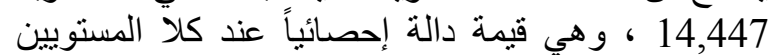

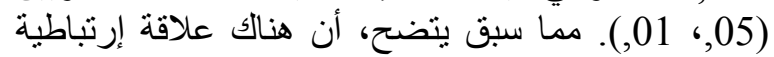

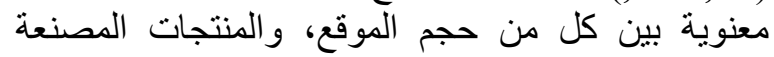
بالمنشآت الصناعية الصغيرة، وهو ما يثبت صلت صحة البند

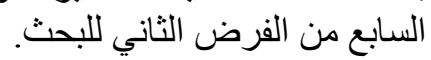

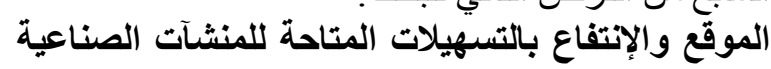

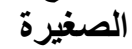

Facilities إن نسبة الإنتفاع بالتسهيلات المتاحة Available

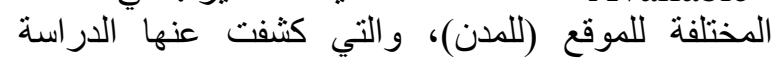

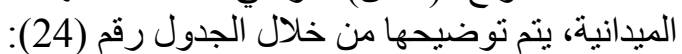

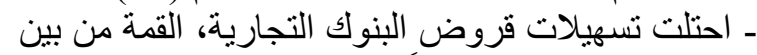

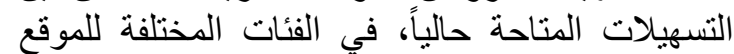

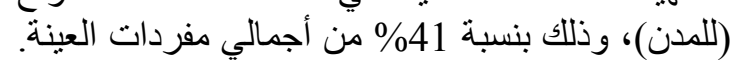

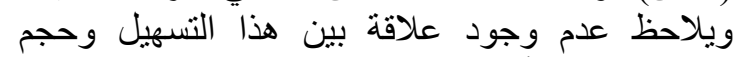

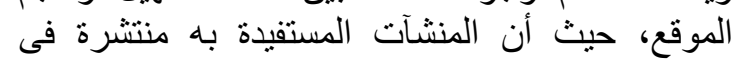

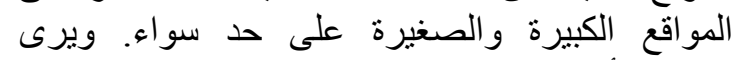

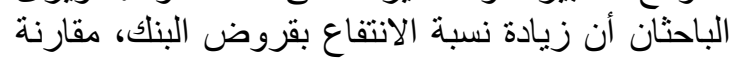

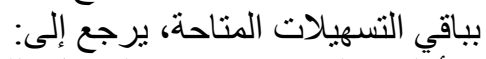

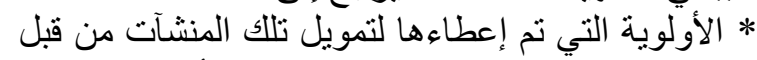

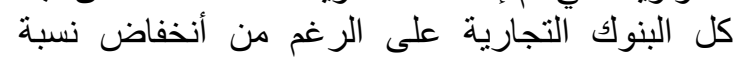

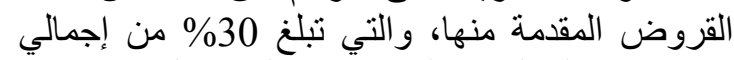

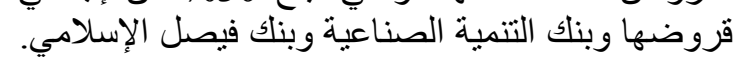

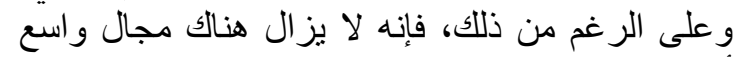

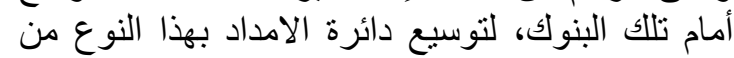

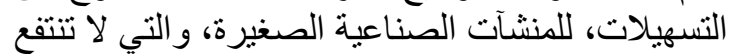

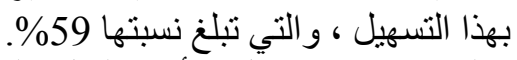

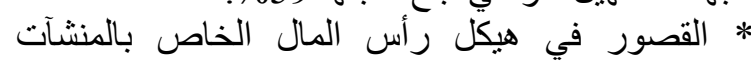

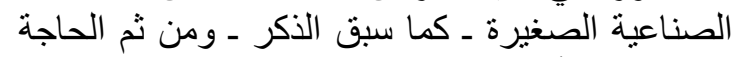
الدائمة إلى الأموال. - المئل

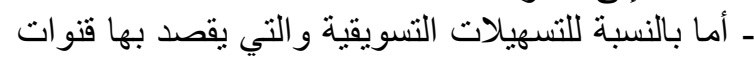

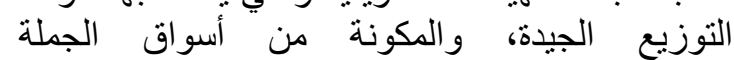
Wholesale المنتجات المصنعة، فيلاحظ أنها تحنل المركزة المركز الثناني

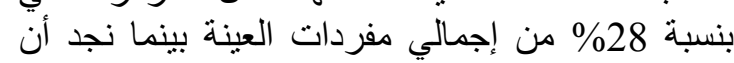

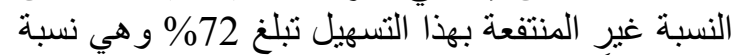

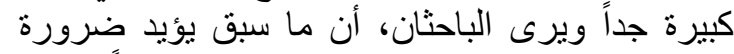

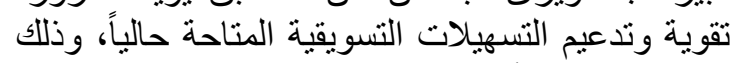

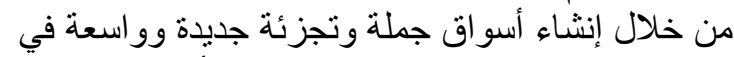

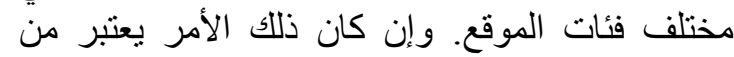


جدول (23): تحليل التباين أحادي الإتجاه لتحديد معنوية العلاقة بين حجم الموقع والمنتجات مصنعة بالمنشآت الصناعية الصغيرة

\begin{tabular}{|c|c|c|c|c|c|}
\hline الالالة الإحصائية & $\mathbf{F}$ & التباين المقدر & درجات الحرية & مجموع المربعات & مصادر التباين \\
\hline معنوية & 14,447 & 330,971 & 10 & 3309,709 & بين المجموعات \\
\hline & & 22,909 & 44 & 1008,8000 & داخل المجموعات \\
\hline & & & 54 & 4317,709 & التباين الكلي \\
\hline
\end{tabular}

جلول (24) : نسبة المنثآت الصناعية الصغيرة محل الدراسة المنتفعة بالتسهيلات المتاحة في الفئات للموقع

\begin{tabular}{|c|c|c|c|c|c|c|c|c|c|c|c|c|}
\hline \multirow{2}{*}{\multicolumn{2}{|c|}{ الإجمالي }} & & & \multicolumn{8}{|c|}{ الموقع (فئات المدن) } & \multirow{3}{*}{ التسهيلات المتاحة } \\
\hline & & \multicolumn{2}{|c|}{ 5- فئة } & \multicolumn{2}{|c|}{ 4- فئة } & \multicolumn{2}{|c|}{ فئة } & \multicolumn{2}{|c|}{ 2- فئة } & \multicolumn{2}{|c|}{ فئة } & \\
\hline$\%$ & عدد & $\%$ & عدد & $\%$ & عدد & $\%$ & عدد & $\%$ & 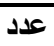 & $\%$ & عدد & \\
\hline 41 & 157 & 41 & 21 & 44 & 19 & 41 & 29 & 43 & 34 & 39 & 54 & القروض من البنوك \\
\hline 28 & 107 & 31 & 16 & 26 & 11 & 30 & 21 & 25 & 20 & 28 & 39 & التسويق \\
\hline 10 & 37 & 4 & 2 & 9 & 4 & 7 & 5 & 10 & 8 & 13 & 18 & الإنتفاع بالمواد الخام المستوردة \\
\hline 5 & 20 & 6 & 3 & 5 & 2 & 6 & 4 & 8 & 6 & 4 & 5 & القروض من التعاونيات الخاصة \\
\hline 3 & 10 & 4 & 2 & 2 & 1 & 3 & 2 & 3 & 2 & 2 & 3 & إستئجار الماكينات \\
\hline 3 & 10 & 4 & 2 & 2 & 1 & 1 & 1 & 3 & 2 & 3 & 4 & معدلات الفائدة المنخفضة \\
\hline 3 & 10 & 2 & 1 & 2 & 1 & 3 & 2 & 3 & 2 & 3 & 4 & إنخفاض معدلات الضر ائب \\
\hline 3 & 10 & 2 & 1 & 5 & 2 & 3 & 2 & 1 & 1 & 3 & 4 & إنخفاض رأس المال المستثمر \\
\hline 5 & 20 & 6 & 3 & 5 & 2 & 6 & 4 & 5 & 4 & 5 & 7 & أخرى \\
\hline 100 & 381 & 100 & 51 & 100 & 43 & 100 & 70 & 100 & 79 & 100 & 138 & الإجمالي \\
\hline
\end{tabular}

المصدر: إستمارة الإستبيان.

جدول (25) : تحليل التباين أحادي الإتجاه لتحديد معنوية العلاقة بين حجم الموقع والإنتفاع بالتسهيلات المتاحة في الفئات المختلفة للموقع

\begin{tabular}{|c|c|c|c|c|c|}
\hline الدلالة الإحصائية & $\mathbf{F}$ & التباين المقدر & درجات الحرية & مجموع المربعات & مصادر التباين \\
\hline معنوية & 14,110 & 563,450 & 8 & 4507,600 & بين المجموعات \\
\hline & & 39,933 & 36 & 1437,600 & اخل المجموعات \\
\hline & & & 44 & 5945,200 & التباين الكلي \\
\hline
\end{tabular}

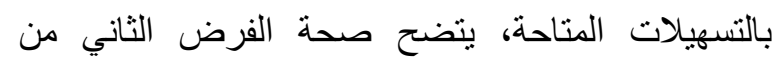

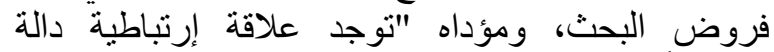

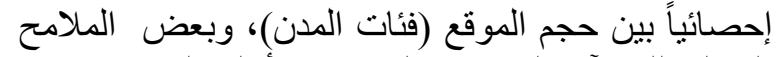

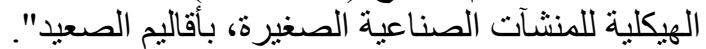

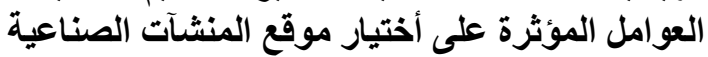

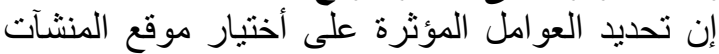
الصناعية الصغيرة، في الفئات المختلفة للموقع (المدن)، يعتبر من وجهة نظر الباحثان ـ أمراً ذو فائدة من ناحيتين أساسيتين هما:

- يمكن من إجراء دراسة مقارنة للمواقع من مختلفة

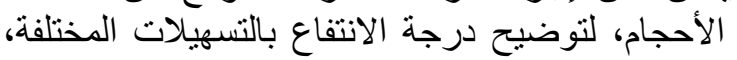

بالنسبة للمنشآت المتوطنة بكل موقع من تللك المو اقع.

ـ تزويد السلطات المحلية Local Authorities و غيلة الفير ها

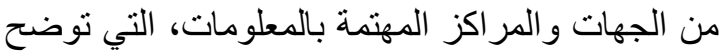

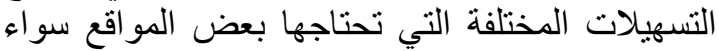
لبدء أو توسيع الصناعة بها. وسوف يقوم الباحثان فيما يلي، بتحديد العيداعة العوامل التي تحكم أختيار موقع النشاطات الصناعية الصغيرة في الفئات

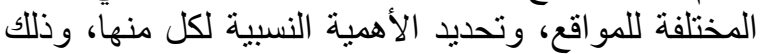

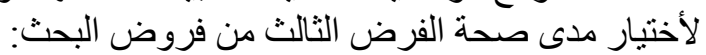

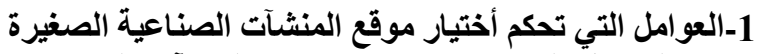
إن العوامل المؤثرة في اختيار موقع المنشآت الصناع الصناعية الصناع الصنية
وقد أفاد التحليل الإحصائي بأن هذه النتائج معنوية، حيث بلغت قيمة كا2

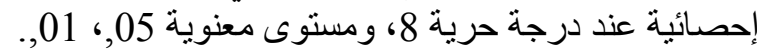

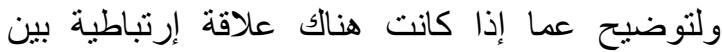

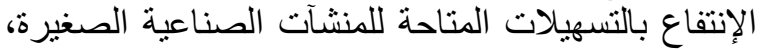

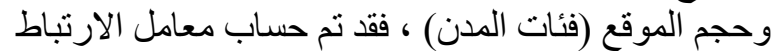
المتعدد، كما تم إستخدام تحليل التباين أحادي الاتجاه لبيان فيان

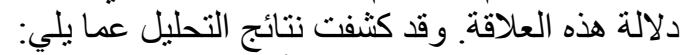

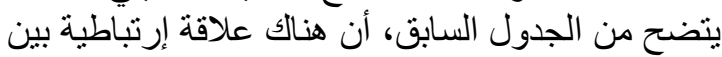

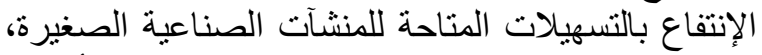

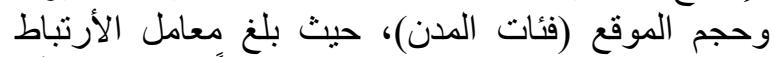

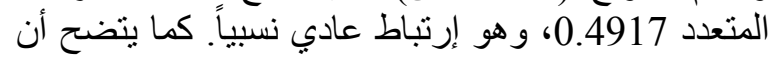

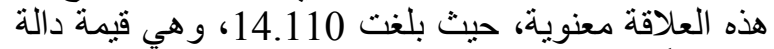
إحصائياً عند كلا المستوبين (0.05، 0.01، 0.01). مما سبق يتضح أن هنالك علاقة إرتباطية معنوية بين

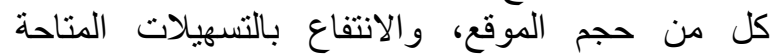

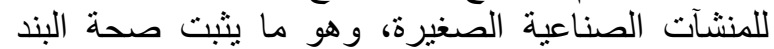
الثامن للبحث. بناء على التحليل السابق للعلاقة بين حجم الموقع وكل

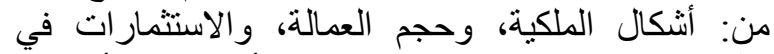

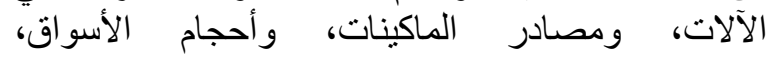
ومصادر المواد الخام، والمنتجات المصنعة، و والانتفاع الأوات 
- يعتبر كل من القرب من الأسواق، والخطط المستقبلية،

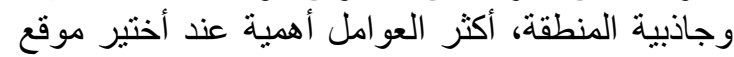

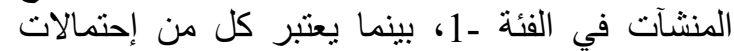

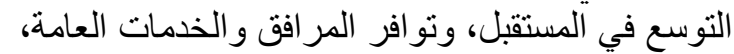

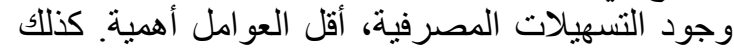

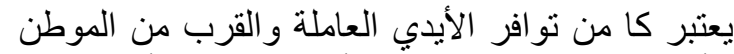

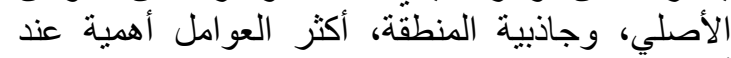

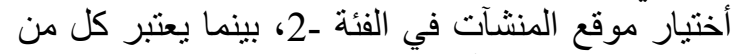

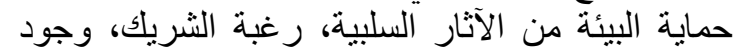
التسهيلات المصرفية، أقل العو امل أهمية.

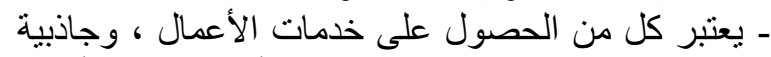

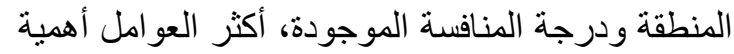

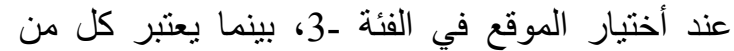

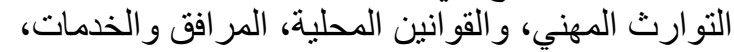

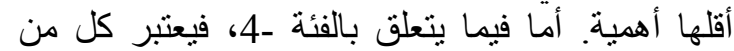

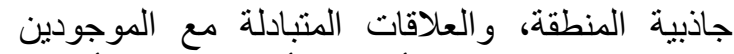

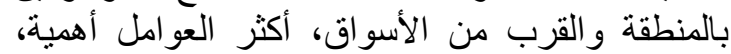

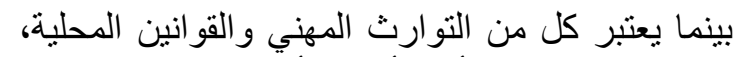

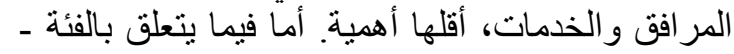

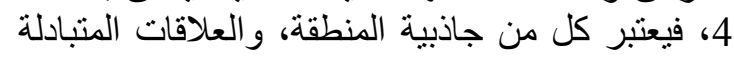

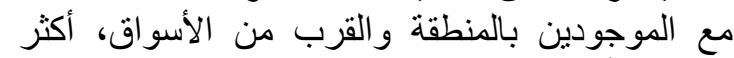

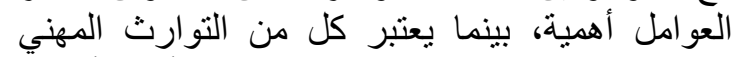

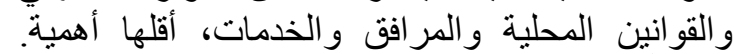

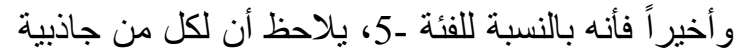

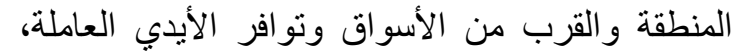

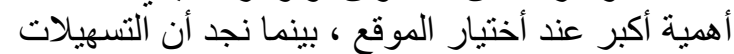

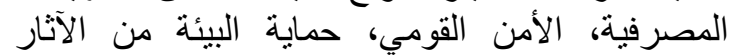
السلبية، أهمية أقل عند إختيار موقع المنشآت الصناعية الصنية

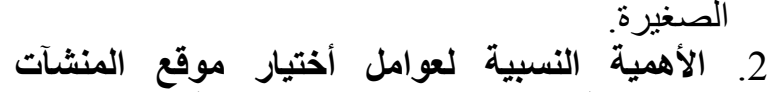

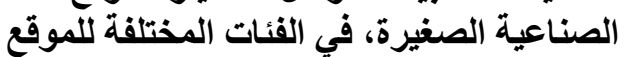

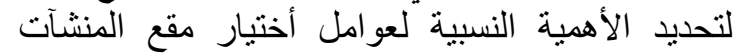

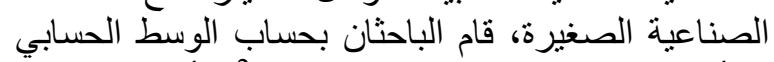

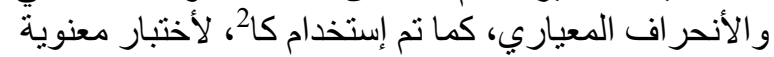

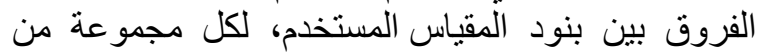

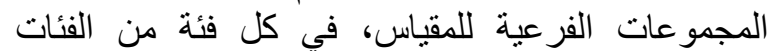

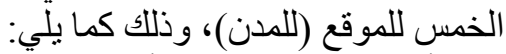

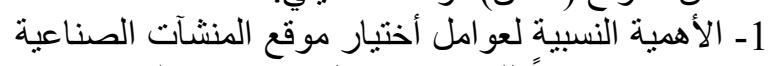

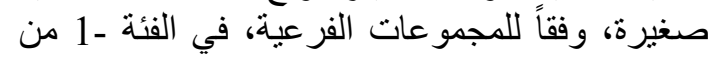

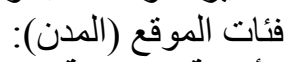

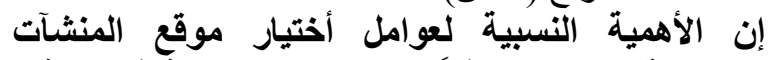

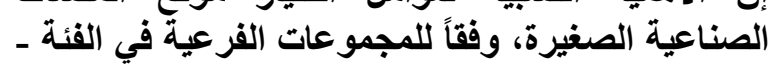

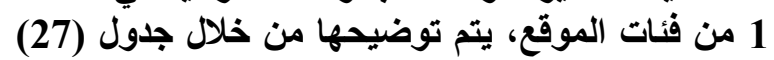

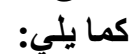

ـ أن العو امل الفنية تحتل المرتبة الأولى، من حيث الأهمية

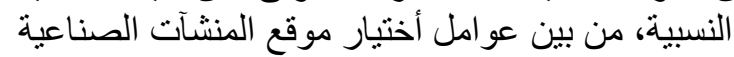
الصغيرة، حيث بلغ الوسط الحسابي العام لتكرارات التهات التهات المجموعة 50.14 بانحراف لفيط معياري قدره

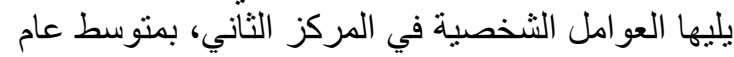

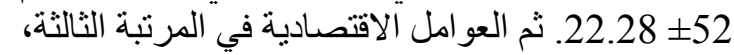

الصغيرة، في الفئات المختلفة للموقع، والتي كثفت عنها الدراسة الميدانية، يتم توضيحها من خلال الجدول رقي

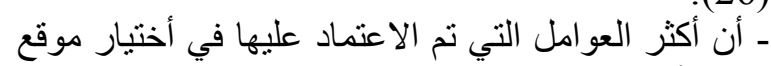

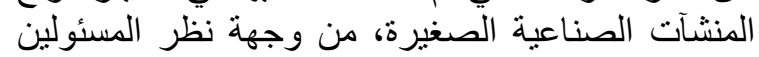

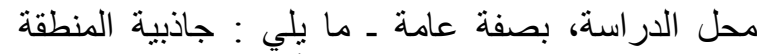

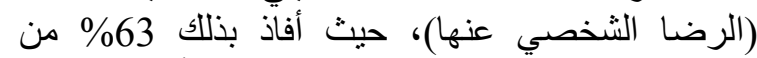

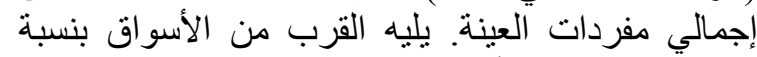

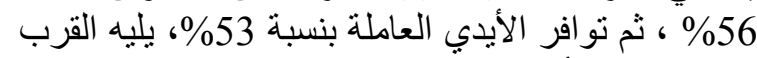

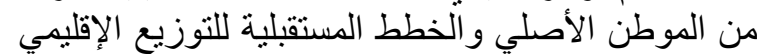

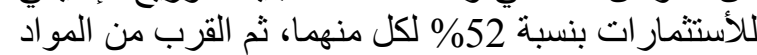

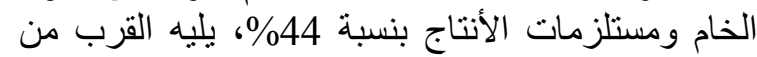

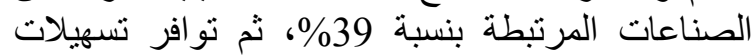

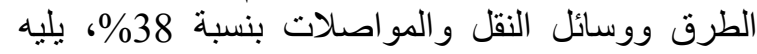

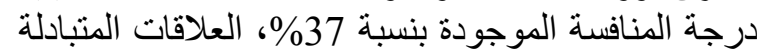

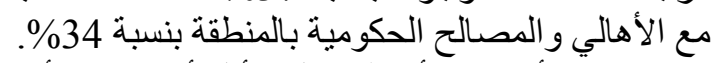

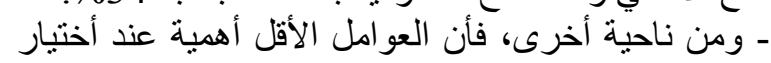

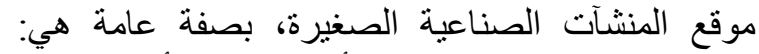

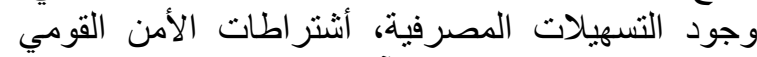

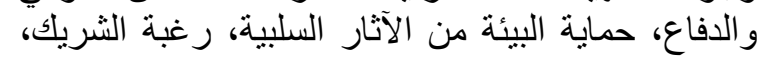

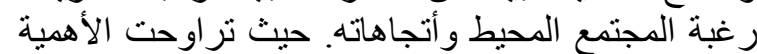

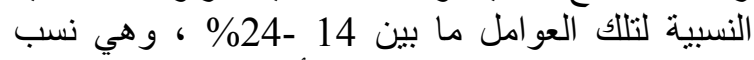
منخفضة إلى حد كبير، بالمقارنة بأهمية هذه العو امل عند ند

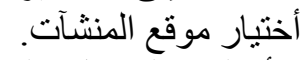

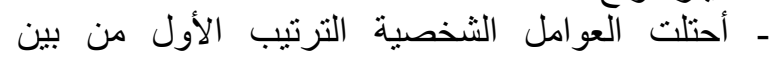

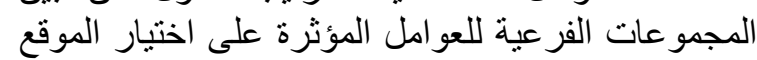

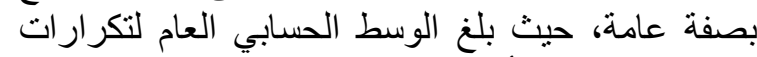

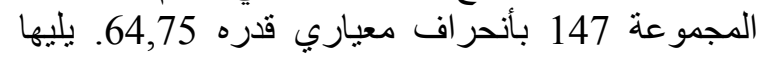

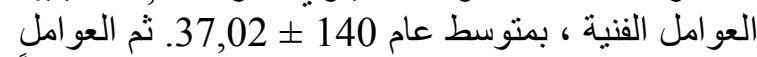

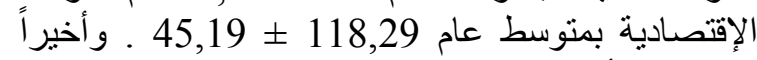

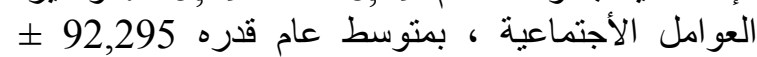

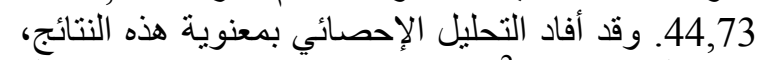
حيث بلغت قيمة كا² نحو

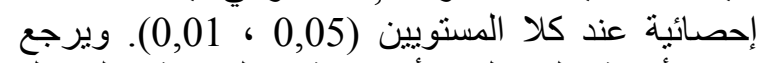

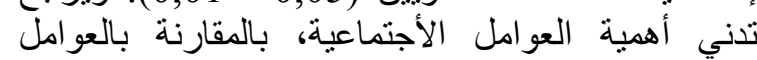

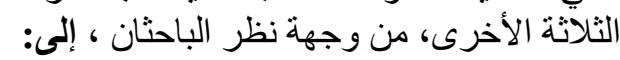

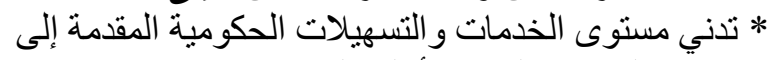
معظم المو اقع (المدن) بأقاليم الصعيد.

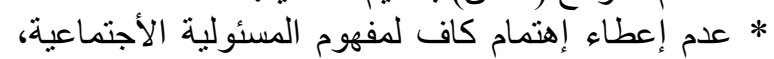

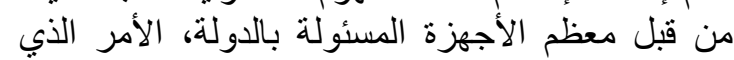

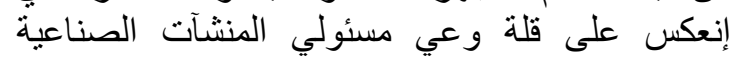
الصغيرة بأهميتها.

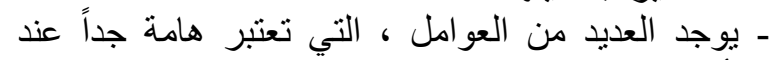

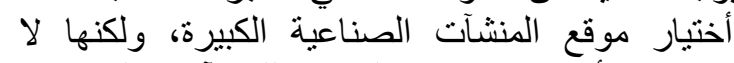

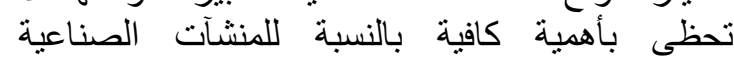

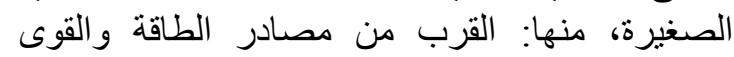
المحركة، سهولة المهلة الحصول على منى خدمات الأعمال

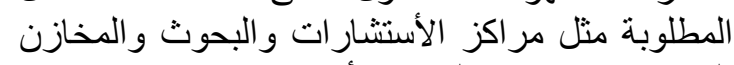

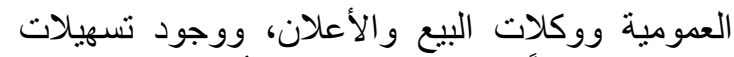
مصرفية، فضلاً عن معظم العو امل الأجتماعية. 
جدول (26): الأهمية النسبية لعو امل إختيار موقع المنشآت الصناعية الصغيرة في الفئات المختلفة للموقع، كما يدركها المسئولين عنها

\begin{tabular}{|c|c|c|c|c|c|c|c|c|c|c|c|c|c|c|c|c|c|c|}
\hline \multirow{2}{*}{\multicolumn{3}{|c|}{ 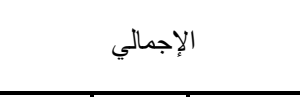 }} & \multicolumn{15}{|c|}{ فئات المدن } & \multirow{2}{*}{ عو امل اختيار الموقع } \\
\hline & & & \multicolumn{3}{|c|}{ فئئة -5 } & \multicolumn{3}{|c|}{ فئة -4- } & \multicolumn{3}{|c|}{ فئة -3 } & \multicolumn{3}{|c|}{ 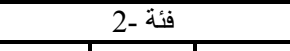 } & \multicolumn{3}{|c|}{ فئة - 1 - } & \\
\hline ترتيب & نسبة & 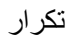 & ترنيب & 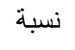 & 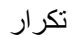 & ترتيب & 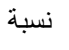 & 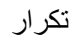 & ترتيب & نسبة & 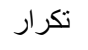 & ترتيب & 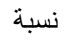 & 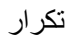 & ترنيب & نسبة & 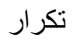 & أولاً: العوامل الفنية: \\
\hline 6 & 44 & 167 & 2 & 63 & 32 & 9 & 42 & 18 & 11 & 34 & 24 & 5 & 44 & 35 & 7 & 42 & 58 & 1ـ القرب من المو اد الخام ومستلزمات الأنتاج \\
\hline 12 & 30 & 116 & 13 & 29 & 15 & 12 & 35 & 15 & 16 & 27 & 19 & 11 & 34 & 27 & 12 & 29 & 40 & 2- القرب من مصادر الطاقة والقوى المحركة \\
\hline 3 & 53 & 201 & 6 & 43 & 22 & 4 & 60 & 26 & 10 & 36 & 25 & 1 & 75 & 59 & 5 & 50 & 69 & 3- ت توافر الأيدي العاملة \\
\hline 20 & 19 & 74 & 19 & 18 & 9 & 21 & 14 & 6 & 21 & 20 & 14 & 13 & 30 & 24 & 21 & 15 & 21 & 4- تو افر الظروف المناخية والطبيعية المناسبة \\
\hline 10 & 34 & 129 & 18 & 20 & 10 & 18 & 21 & 9 & 1 & 64 & 45 & 19 & 23 & 18 & 11 & 34 & 47 & 5- سهولة الحصول على خدمات الأعمال المطلوبة \\
\hline 8 & 38 & 145 & 9 & 37 & 19 & 15 & 28 & 12 & 6 & 43 & 30 & 10 & 35 & 28 & 8 & 41 & 56 & 6- تو افر تسهيلات الطرق ووسائل النقل و المو اصلات \\
\hline \multirow[t]{2}{*}{7} & 39 & 148 & 11 & 33 & 17 & 8 & 47 & 20 & 15 & 25 & 20 & 7 & 39 & 31 & 6 & 43 & 60 & 7- القرب من الصناعات المرتبطة (أمامباً وخلفياً) \\
\hline & & & & & & & & & & & & & & & \multicolumn{4}{|r|}{ نُّانياً: العوامل الإقتصادية: } \\
\hline 13 & 28 & 107 & 16 & 24 & 12 & 17 & 23 & 10 & 8 & 39 & 27 & 18 & 24 & 19 & 13 & 28 & 39 & 8- أنخفاض تكاليف الأرض و البناء و التشغيل \\
\hline 13 & 28 & 108 & 14 & 27 & 14 & 11 & 37 & 16 & 14 & 30 & 21 & 12 & 32 & 25 & 15 & 23 & 32 & 9- وجود تسهيلات ضريبية \\
\hline 17 & 26 & 100 & 15 & 25 & 13 & 20 & 16 & 7 & 9 & 37 & 26 & 20 & 22 & 17 & 14 & 27 & 37 & 10 10 أنخفاض تكلفة النقل \\
\hline 26 & 14 & 54 & 22 & 12 & 6 & 19 & 19 & 8 & 19 & 23 & 16 & 24 & 9 & 7 & 24 & 12 & 17 & 11- وجود التسهيلات المصرفية \\
\hline 2 & 56 & 213 & 10 & 35 & 18 & 3 & 65 & 28 & 18 & 24 & 17 & 6 & 43 & 34 & 1 & 84 & 116 & 12 - القرب من الأسواق \\
\hline 13 & 28 & 106 & 5 & 45 & 23 & 6 & 51 & 22 & 17 & 26 & 18 & 4 & 46 & 36 & 26 & 5 & 7 & 13- إحتمالات التوسع في المستقبل \\
\hline \multirow[t]{2}{*}{9} & 37 & 140 & 8 & 39 & 5 & 14 & 30 & 13 & 3 & 56 & 39 & 9 & 37 & 29 & 9 & 39 & 54 & 14- درجة المنافسة الموجودة \\
\hline & & & & & & & & & & & & & & & \multicolumn{4}{|r|}{ ثالثاً: العو امل الإجتماعية: } \\
\hline 20 & 19 & 74 & 12 & 31 & 16 & 25 & 5 & 2 & 26 & 7 & 5 & 17 & 25 & 21 & 16 & 22 & 30 & 15- القو انين المحلية السائدة \\
\hline 19 & 22 & 84 & 26 & 4 & 2 & 5 & 53 & 23 & 23 & 17 & 12 & 16 & 26 & 21 & 19 & 19 & 26 & 16- التسعيلات الحكومية الممنوحة للمنطقة \\
\hline 24 & 16 & 60 & 23 & 10 & 5 & 23 & 10 & 4 & 24 & 16 & 11 & 22 & 19 & 15 & 20 & 18 & 25 & 17 أُشتُر اطات الأمن القومي و الدفاع \\
\hline 22 & 18 & 69 & 17 & 22 & 11 & 16 & 26 & 11 & 20 & 21 & 15 & 23 & 18 & 14 & 23 & 13 & 18 & 18- رغبات المجتمع المحيط وأتجاهاته \\
\hline 16 & 27 & 101 & 20 & 16 & 8 & 24 & 7 & 3 & 25 & 9 & 60 & 21 & 20 & 16 & 25 & 10 & 14 & 19- المر افق و الخدمات العامة \\
\hline 24 & 16 & 61 & 21 & 14 & 7 & 10 & 40 & 17 & 22 & 19 & 13 & 26 & 6 & 5 & 22 & 14 & 19 & 20 - 20 حماية البيئة من الآثار السلبية \\
\hline \multirow[t]{2}{*}{4} & 52 & 197 & 7 & 41 & 21 & 7 & 49 & 21 & 4 & 50 & 35 & 8 & 38 & 30 & 2 & 65 & 90 & 21- الخطط المستقبلية للتوزيع الإقليمي للأستثمار ات \\
\hline & & & & & & & & & & & & & & & & & & رابعا: العو امل الثخصية: \\
\hline 4 & 52 & 200 & 3 & 57 & 29 & 13 & 33 & 14 & 5 & 46 & 32 & 2 & 67 & 53 & 4 & 52 & 72 & 22 - القرب من الموطن الأصلي \\
\hline 1 & 63 & 241 & 1 & 65 & 33 & 1 & 74 & 32 & 2 & 61 & 43 & 3 & 63 & 50 & 3 & 60 & 83 & 23- جاذيبة المنطقة (الرضا الثخضصي عنها) \\
\hline 10 & 34 & 131 & 4 & 47 & 24 & 2 & 70 & 30 & 7 & 40 & 28 & 15 & 27 & 21 & 18 & 20 & 28 & بالمنطقة العلاقات المتبادلة مع الأهالي و الدصالح الحكومية \\
\hline 18 & 25 & 97 & 25 & 6 & 3 & 26 & 2 & 1 & 12 & 33 & 23 & 14 & 28 & 22 & 10 & 35 & 48 & 25- التوارث المهني \\
\hline \multirow[t]{2}{*}{23} & 17 & 66 & 24 & 8 & 4 & 22 & 12 & 5 & 13 & 31 & 22 & 25 & 8 & 6 & 17 & 21 & 29 & 26- رغبة الثريك \\
\hline & 100 & 381 & & 100 & 51 & & 100 & 43 & & 100 & 70 & & 100 & 79 & & 100 & 138 & الإجمالي \\
\hline
\end{tabular}




$$
\text { (جدول 26). }
$$

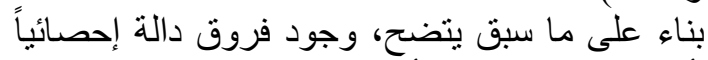

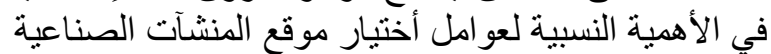

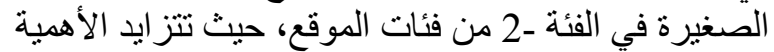

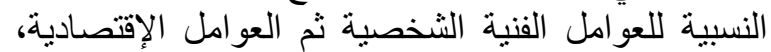
وتقل الأهمية النسبية للعو امل الأجتماعية.

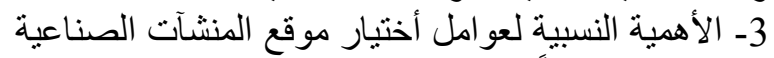

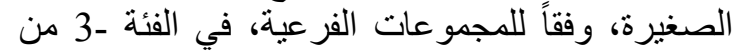

$$
\text { فئات الموقع (المدن): }
$$

إن الأهية النسبية لعوامل المئية اختيار موقع المنشآت

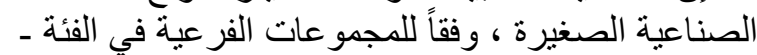

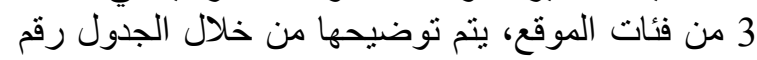

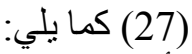

ـ أن العو امل الثخصية، تحتل المرتبة الأولى من حيث الأهمية من بين عوامل أختيار موقع المنشآت الصنية الصناعية الصنية

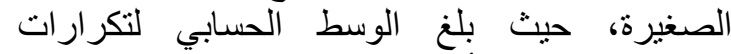

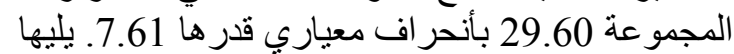

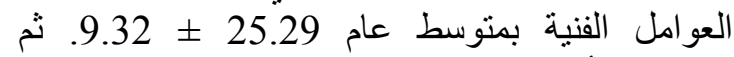

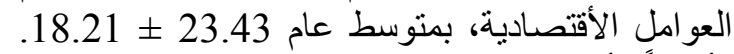

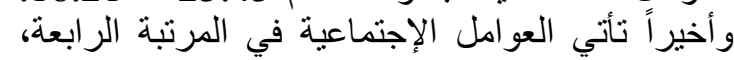
بمتوسط عام 21.57 ـ 17.94. ـ أما بالنسبة لنتائج اختبار كائ، فكانت على على النحو التالي:

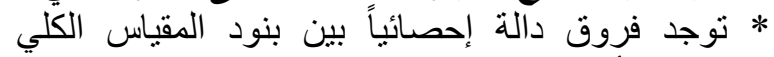

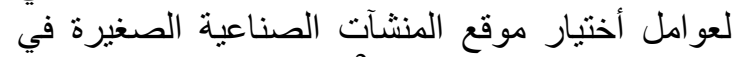

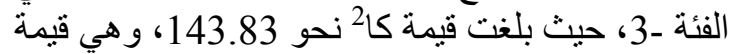
ذات دلالة إحصائية عند درجة حرية 25 25، ومستوى

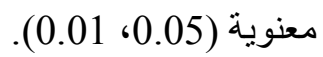
* توجد فروق دالة إحصائياً في بنود مجموعات العو امل

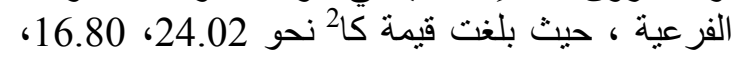

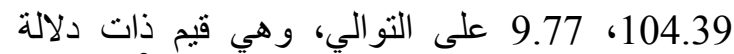

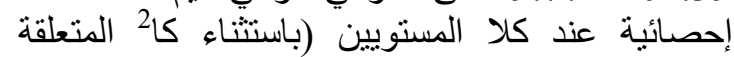

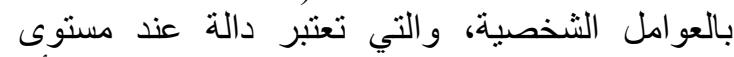

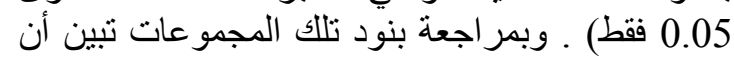

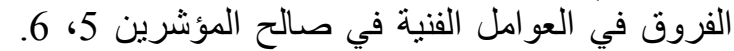

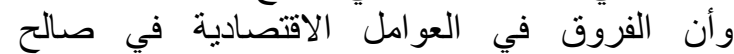

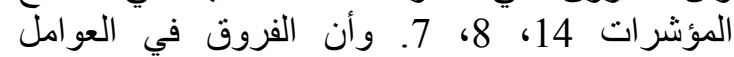

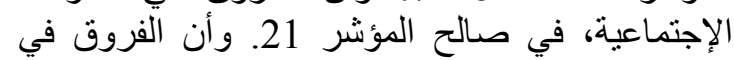
العو امل الثخصية في صالح المؤشرات 22، 22، 23، 24.

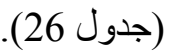

مما سبق يتبين أنه ، نوجد فروق دالة إحصائياً في

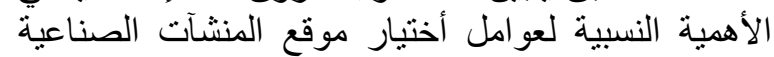

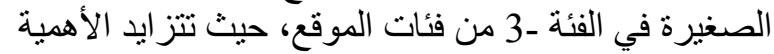
النسبية للعو امل الثخصية و الفنية ثم العو امل الإقتصادية، وتقل الأهمية النسبية للعو امل الأجنماعية. 4- الأهمية النسبية لعوامل أختيار موقع المنشآت الصناعية الصنية

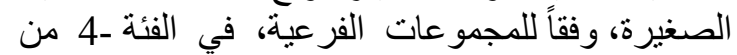

$$
\text { فئات الموقع (المدن): }
$$

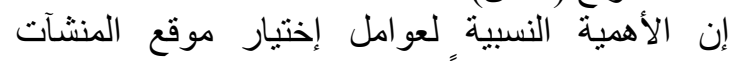

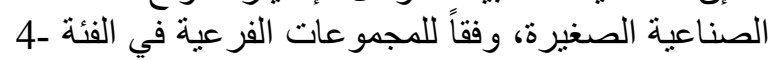
من فئات الموقع، يتم توضيحها ولناً للجن خلال الجدول (27) كما يلي:

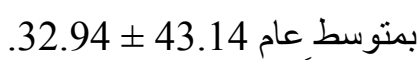
وأخير اً تأتي مجمو عة العو امل الإجتماعية في المرتبة

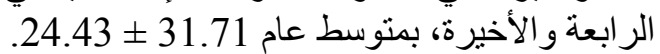

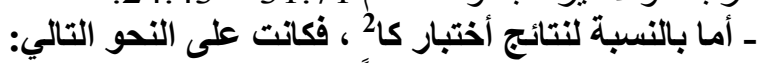

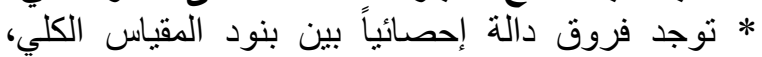

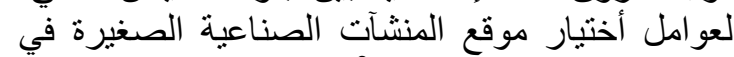

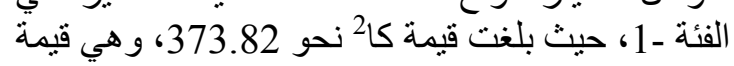
ذات دلالة إحصائية عند درجة فيمة حرية 25، 25، ومسنتوى

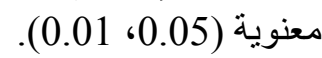

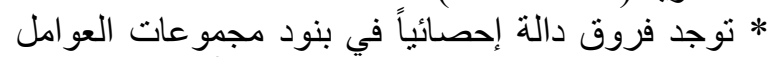

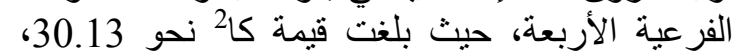

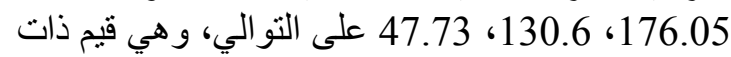

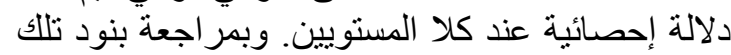

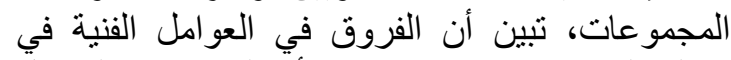

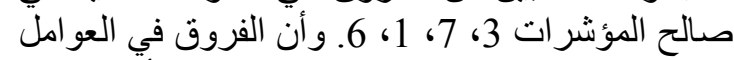
الاقتصادية في صالح المؤشرين 12، 12، 14. 14. وأن النئ الفروق العرو

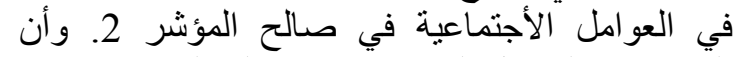

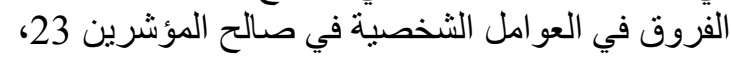

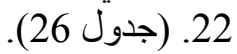

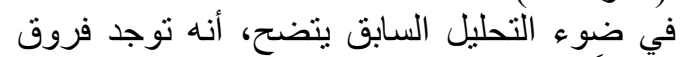

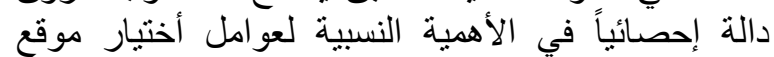

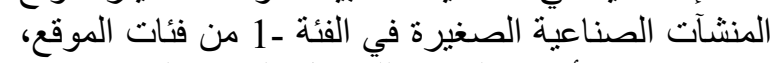

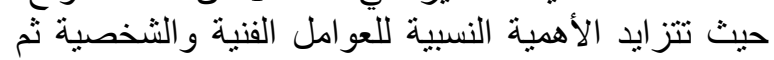

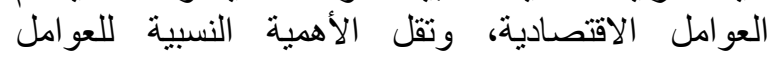

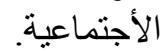
2- الأهمية النسبية لعو امل أختبار موقع المنشآت الصناعية

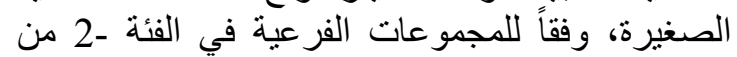

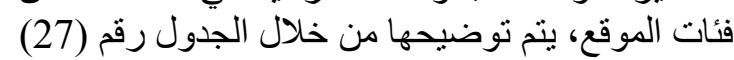

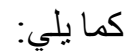
ـ أن العوأمل الفنية تحتل المرتبة الأولى، حيث بلغ الوسط

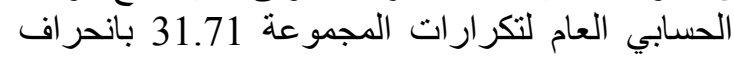
معياري قدره 12.19. يليها العو امل العو امل الثخصية

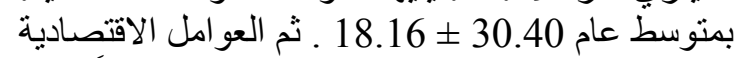

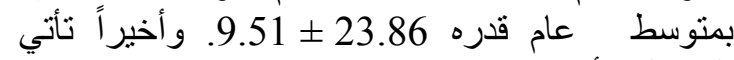
العو امل الأجتماعية بمتوسط عام عام قدره 17.43 د 17.86.

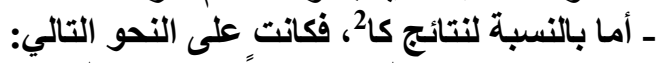

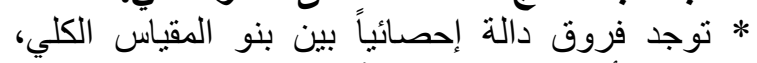

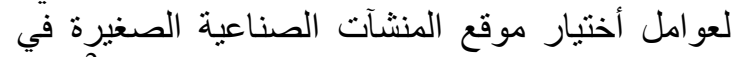

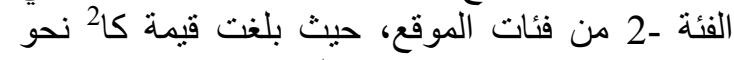

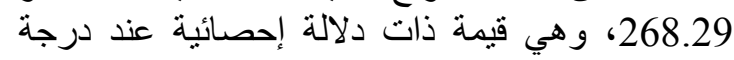

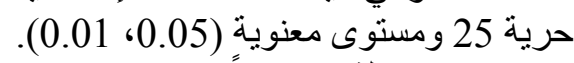

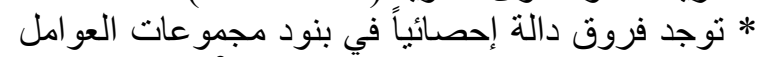

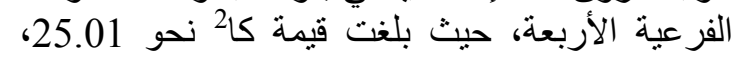

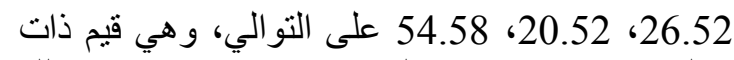

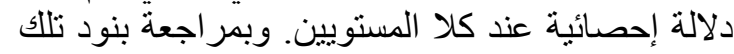

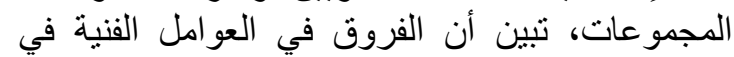

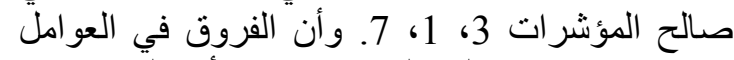

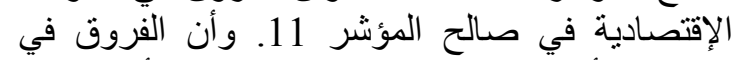

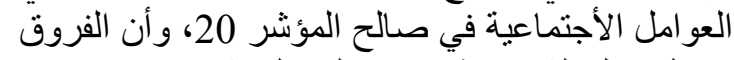
في العوامل الثخصية في صنالح المؤشرين 22، وان النئ 23. 


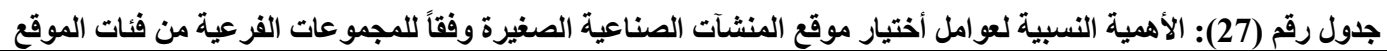

\begin{tabular}{|c|c|c|c|c|c|c|c|}
\hline قيمة كاكا2 & ترتيب & إنحراف معياري & وسط حسابي & تكرار الأعلى & تكرار الأدنى & عدد بنود المقياس & المجموعات الفرعية \\
\hline & & & & & & & الفئة -1- \\
\hline 30,13 & 1 & 14,69 & 50,14 & 69 & 21 & 7 & 1- العوامل الفنية \\
\hline 176,05 & 3 & 32,94 & 43,14 & 116 & 7 & 7 & 2- العوامل الاقتصادية \\
\hline 130,60 & 4 & 24,43 & 31,71 & 90 & 14 & 7 & 3- العوامل الإجتماعية \\
\hline 47,73 & 2 & 22,28 & 52 & 72 & 28 & 5 & 4- العوامل الثخصية \\
\hline \multirow[t]{2}{*}{ 373,82 } & & 25,85 & 43,65 & 116 & 7 & 26 & المقياس الكلى \\
\hline & & & & & & & الفئة -2 \\
\hline 25,51 & 1 & 12,19 & 31,71 & 59 & 18 & 7 & 1- العوامل الفنية \\
\hline 26,52 & 3 & 9,51 & 23,86 & 36 & 7 & 7 & 2- العوامل الاقتصادية \\
\hline 20,52 & 4 & 7,15 & 17,43 & 30 & 5 & 7 & 3- العوامل الإجتماعية \\
\hline $\mathbf{5 4 , 5 8}$ & 2 & 18,16 & 30,40 & 53 & 6 & 5 & 4- العوامل الثخصية \\
\hline \multirow[t]{2}{*}{268,29} & & 13,20 & 25,50 & 59 & 5 & 26 & المقياس الكلي \\
\hline & & & & & & & الفئة -33 \\
\hline 24,02 & 1 & 9,32 & 25,29 & 45 & 14 & 7 & 1- العوامل الفنية \\
\hline 16,80 & 3 & 18,21 & 23,43 & 39 & 16 & 7 & 2- العوامل الاقتصادية \\
\hline 104,39 & 4 & 17,94 & 21,57 & 60 & 5 & 7 & 3- العوامل الإجتماعية \\
\hline 9,77 & 2 & 7,61 & 29,60 & 43 & 22 & 5 & 4- العوامل الثخصية \\
\hline \multirow[t]{2}{*}{143,83} & & 6,29 & 24,62 & 60 & 5 & 26 & المقياس الكلي \\
\hline & & & & & & & 4- الفئة \\
\hline 18,55 & 2 & 6,33 & 15,14 & 26 & 6 & 7 & 1- العوامل الفنية \\
\hline 24,29 & 3 & 7,18 & 14,86 & 28 & 7 & 7 & 2- العوامل الاقتصادية \\
\hline 40,78 & 4 & $\mathbf{9 , 8 7}$ & 11,57 & 23 & 2 & 7 & 3- العوامل الإجتماعية \\
\hline 48,84 & 1 & 12,66 & 16,40 & 32 & 1 & 5 & 4ـ العوامل الثخصية \\
\hline \multirow[t]{2}{*}{145,95} & - & 8,76 & 14,35 & 32 & 1 & 26 & المقياس الكلي \\
\hline & & & & & & & 5-5 الفئة 5 \\
\hline 37,41 & 2 & 14,69 & 17,71 & 32 & 9 & 7 & 1- العوامل الفنية \\
\hline 18,46 & 3 & 7,24 & 13 & 23 & 5 & 7 & 2- العوامل الاقتصادية \\
\hline 26 & 4 & 5,86 & 10 & 21 & 2 & 7 & 3- العوامل الإجتماعية \\
\hline 43,08 & 1 & 6,09 & 18,6 & 33 & 3 & 5 & 4- العوامل الثخصية \\
\hline 137,94 & - & 8,73 & 14,54 & 33 & 12 & 26 & المقياس الكلي \\
\hline
\end{tabular}

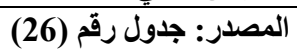

الإقتصادية في صالح المؤشرين 12، 13. و أن الفروق

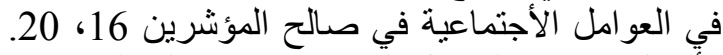
وأن الفروق في العو امل الثخصية في صالح الثي المؤشرين

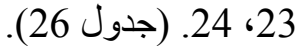

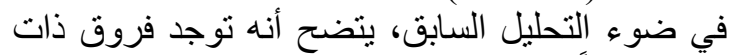

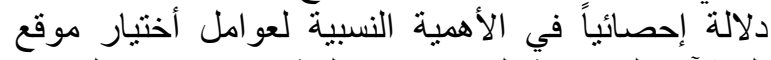

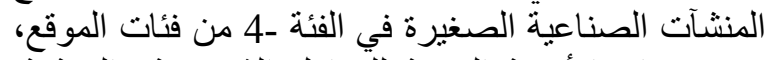

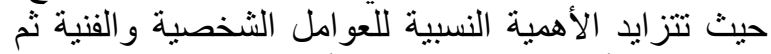

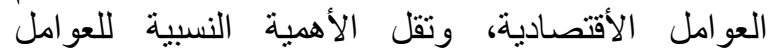

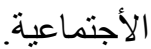
5- الأهمية النسبية لعوامل أختيار موقع المنشآت الصناعية

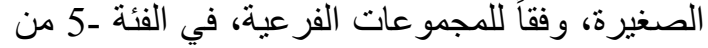
فئات الموقع، يتم توضيحها من خلال الجدول رقمات

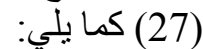
ـ أن العوامل الثخصية قد إحتلت الترتيب الأول من حيث

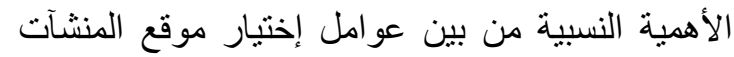

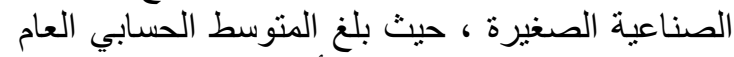

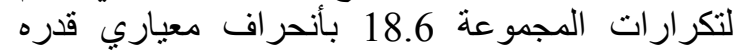
12.66. يليها العوامل الفنية في المرتبة الثانية بمنوسط فئرة

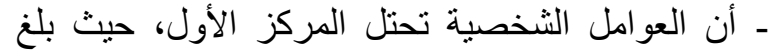
الوسط الحسابي العام لتكرارات المجئ العموعة 16.40 بانحر اف معياري قدره 12.66. يليها العو امل الفنية في

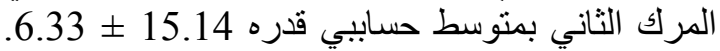

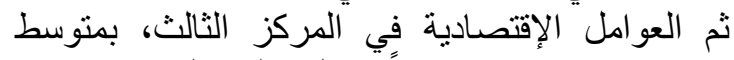

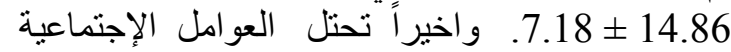

المركز الر ابع، بمتوسط عام قدره 186.

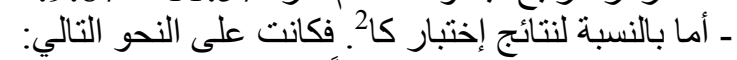

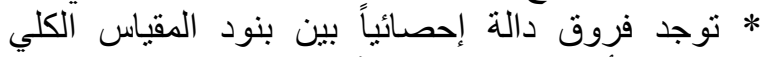

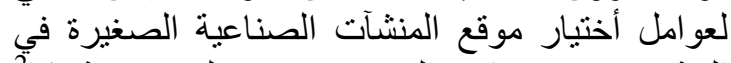

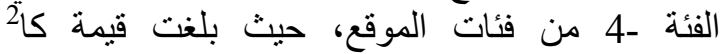
145.59، و هي قيمة ذات دلالة إحصائية عند درجة

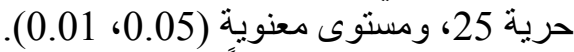

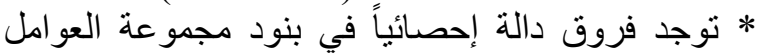

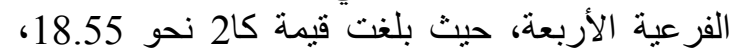

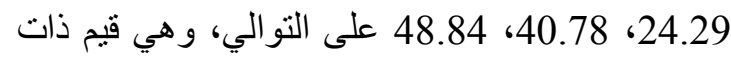

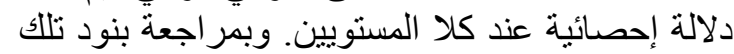

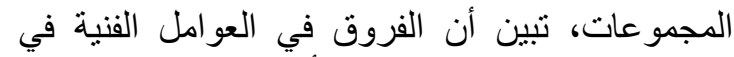
صالح المؤشرات 3، 7 ، 1. 1أن أن الفروق في العوامل 
3- يجب تقوية وتدعيم قنوات التوزيع المتاحة حالياً بأقليم

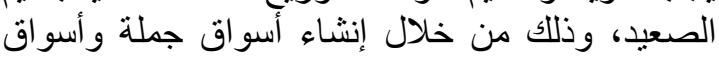

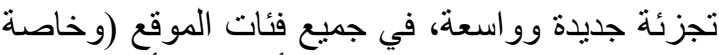

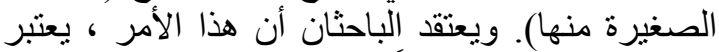

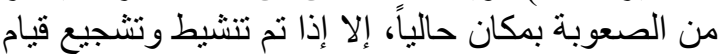
مجمو عة من العمليات الصناعية المتقدمة على الصنيط المنتجات و وتلك المو اقع.

4- ضرورة وضع نظام جديد يحقق العدالة في توزيع

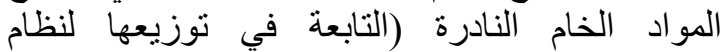
الحصص) على المنشآت الصناعية الصغيرة في الفئئات المختلفة للموقع.

5- يجب العمل على تشجيع إنثاء المراحل الصناعية

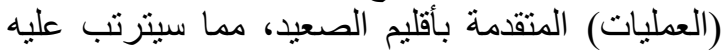

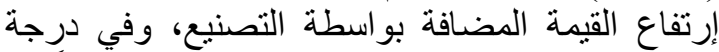

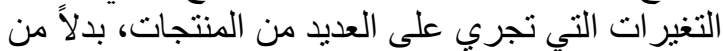

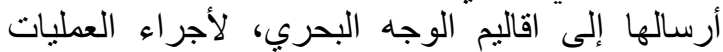
الصناعية المتقدمة عليها.

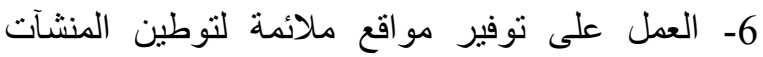

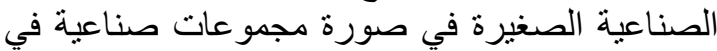

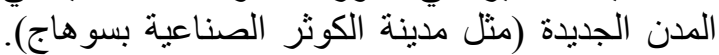
مع تشجيع القطاع الخاص على إنشاء وتنمية هذه

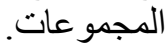

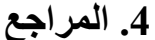

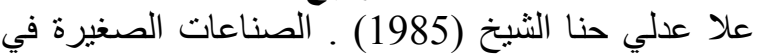

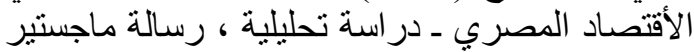

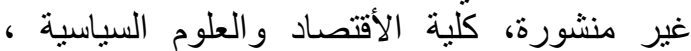

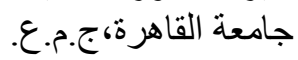

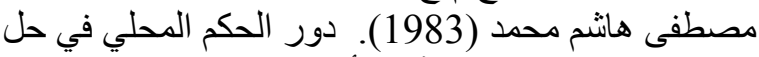

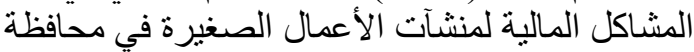
بني سويف، رسالة ماجستير في إدارة الأإعمال، كلية العالة

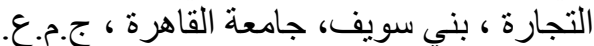

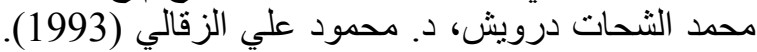

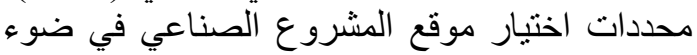

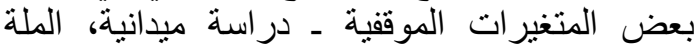
العلمية للأقتصاد و التجارة، كلية التجارة ـ جامعة عين التينة

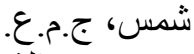
ممدوح فهمي الثرقاوي(1981). الصناعات الصغيرة

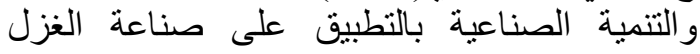
والنسج في مصر. معهد التخطيط: قضايا التخطيط و التنمية في مصر، جـو ج.م.ع. الجهاز المركزي للتعبئة العامة والإحصاء(2013). التعداد العام لسكان و الأسكان و المنشآت. الأعداد الخداء الخاصة بمحافظة الصعيد، اعداد متفرقة. ج.م.ع. الأن.

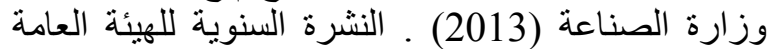
للتصنيع، السجل الصناعي، إدارة التفتيش و المتابعة، لإنة

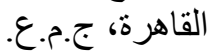

عام قدره 17.71 × 7.24 ـ ثم العو امل الإقتصادية في المرتبة الثالثة بمتوسط عام قدره 13 ـ 17.71 ـ 5.86 ـ و أخيراً تأتي العوامل الإجتماعية في المرتبة الرابعة بمتوسط عام 10 ـ 10.09. ـ أما بالنسبة لنتائج أختبار كا2، فكانت على النحو التالي:

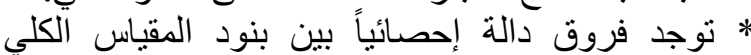

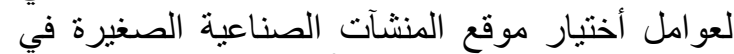

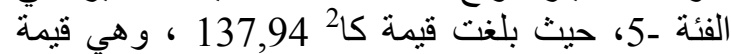
ذات دلالة إحصائية عند درجة حرية 25، 25، ومستوى وهي

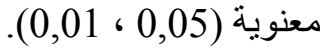

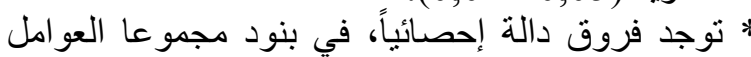

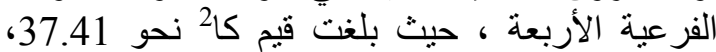

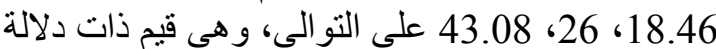

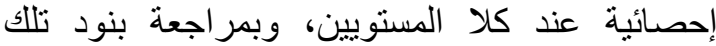
المجموعات ، تبين أن الفروق في العوائ امل الفئية في في

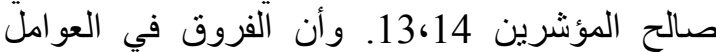

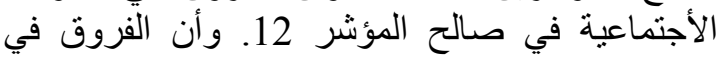
العو امل الثخصية في صالح المؤشرات 22، 23، 23، 24 ـ.

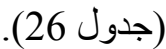

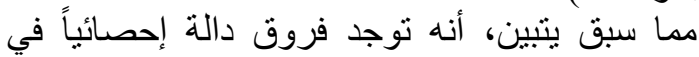

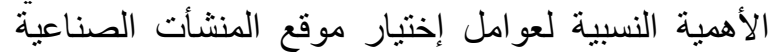

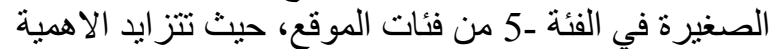
النسبية للعوامل الثخصية والفنية، ثم العوامل الثل الأقتصادية، وتقل الأهمية النسبية للعو امل الأجتماعية.

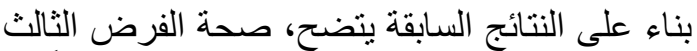

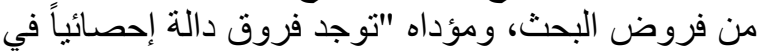
الأهية النسبية لعوامل اختبار موقع المنشآت الصناعية الصناية

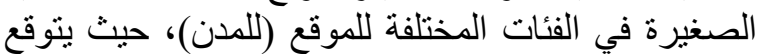

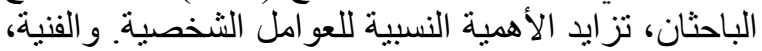
ثم العوامل الإقتصادية، وتقل الإنل الأهمية النسبية للعوامل النمل

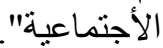

في ضوء النتائج التي تم التوصل إليها، من خلال الدراسة

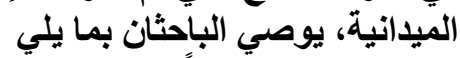
1- بلزم البدء فوراً في رسم خريطة بئية صناعية لأقالبم

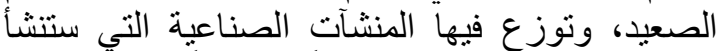

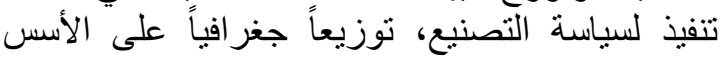

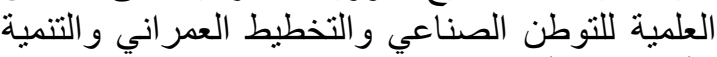

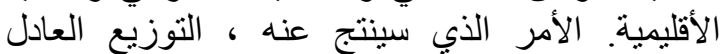

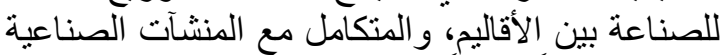
الكبيرة (أمامياً وخلفياً).

2- ضرورة تقديم خدمات الأعمال، والمرتبطة بالمنشآت

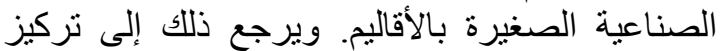

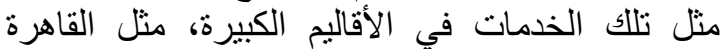

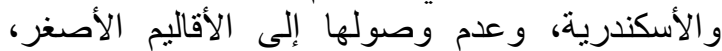
الأمر الذي سيساعد في توطن تلك المنشآت بأقاليم 